WAHE GLER OF

\title{
THE WOODS
}

$$
\text { S RA Dis R R }
$$

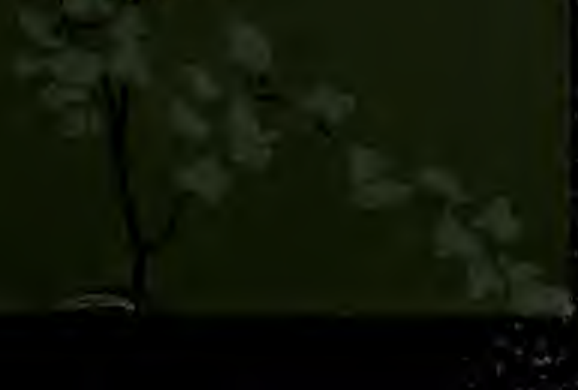




\section{IBRARY}

IVERSITY OF

ALIFORNIA

AN DIEGO

. 
$3^{\circ}$

Fud E. Teay 





\section{ظroks by fftr. Torrey.}

THE CLERK OF THE WOODS. I6mo, \$1.10, net. Postage extra.

FOOTING IT IN FRANCONIA. 16mo, \$1.10, net. Postpaid, \$1.rg.

EVERYDAY BIRDS. Elementary Studies. With twelve colored Illustrations reproduced from Audubon. Square 12mo, \$1.00.

BIRDS IN THE BUSH. $16 \mathrm{mo}$, \$1.25.

A RAMBLER'S LEASE. I6mo, \$1.25.

THE FOOT-PATH WAY. I6mo, gilt top, $\$ 1.25$.

A FLORIDA SKETCH-BOOK. 16mo, \$1.25. SPRING NOTES FROM TENNESSEE. I6mo, \$1.25.

A WORLD OF GREEN HILLS. $16 \mathrm{mo}, \$ \mathrm{r} .25$. FOOTING IT IN FRANCONIA. I6mo, \$1.10, net; postpaid, \$1.20.

HOUGHTON, MIFFLIN \& CO.

Boston AND NEW YoRK. 
THE CLERK OF THE WOODS 


\section{THE CLERK \\ OF THE WOODS}

BY

\section{BRADFORD TORREY}

"News of birds and blossoming."

SHELlex.

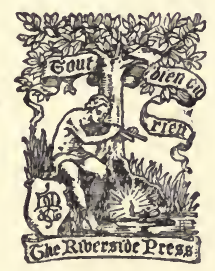

BOSTON AND NEW YORK HODGHTON, MIFFLIN AND COMPANY ctbe tibertior prege, Cambrioge 1903 
COPYRIGHT I9O3 BY BRADFORD TORREY ALL RIGHTS RESERVED

Published September, rgo3 


\section{PREFATORY NOTE}

THE chapters of this book were written week by week for simultaneous publication in the "Evening Transcript" of Boston and the "Mail and Express" of New York, and were intended to be a kind of weekly chronicle of the course of events out-of-doors, as witnessed by a natural-historical observer. The title of the volume is the running title under which the articles were printed in the "Evening Transcript." It was chosen as expressive of the modest purpose of the writer, whose business was not to be witty or wise, but simply to "keep the records." 



\section{CONTENTS}

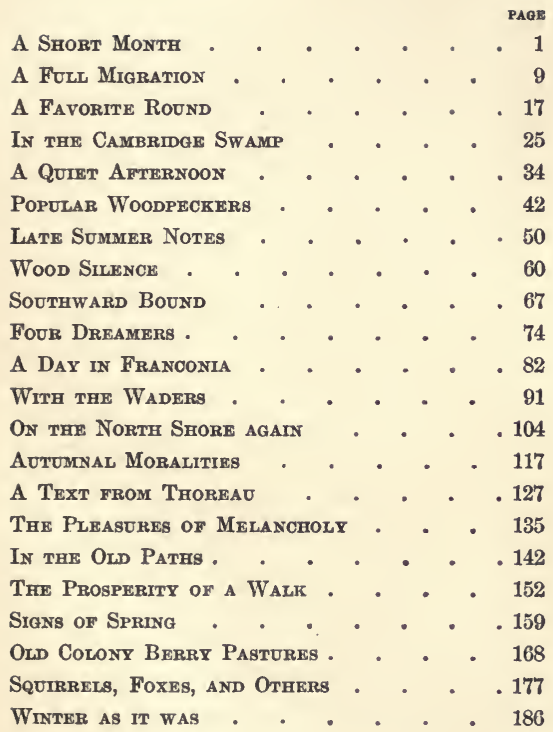


"Down At the Store" . . . . . 194 Brrds at the Window . . . . . 203

A Good-BY to Winter . . . . . . . 212

Bird Soygs and Bird Talk . . . . 219

Chipmunks, Bluebirds, and Robins . . 226

March Swallowg . . . . . . 233

WOODCOCK VESPERS . . . . . . 242

UNDER APRIL Clouds. . . . . . 250

Flying Seutrates and Spade-foot Frogs . 258

The Warblers are comine . . . . 267

INDEX $• .+\quad \cdot \quad \cdot \quad \cdot \quad \cdot \quad 275$ 


\section{THE CLERK OF THE WOODS}





\section{THE CLERK OF THE·WOODS}

\section{A SHORT MONTH}

MAY is the shortest month in the year. February is at least twice as long. For a month is like a movement of a symphony; and when we speak of the length of a piece of music we are not thinking of the number of notes in it, but of the time it takes to play them. May is a scherzo, and goes like the wind. Yesterday it was just beginning, and to-day it is almost done. "If we could only hold it back!" an outdoor friend of mine used to say. And I say so, too. At the most generous calculation I cannot have more than a hundred more of such months to hope for, and I wish the Master's baton would not hurry the tempo. But who knows? Perhaps there will be another series of concerts, in a better music hall.

The world hereabout will never be more 
beautiful than it was eight or ten days ago, with the sugar maples and the Norway maples in bloom and the tall valley willows in young yellow-green leaf. And now forsythia is having its turn. How thick it is! I should not have believed it half so common. Every dooryard is bright with its sunny splendor. "Sunshine bush," it deserves to be called, with no thought of disrespect for Mr. Forsyth, whoever he may have been. I look at the show while it lasts. In a week or two the bushes will all have gone out of commission, so to speak, till the year comes round again. Shrubs are much in the case of men and women; the amount of attention they receive depends mainly on the dress they happen to have on at the moment. In my next-door neighbor's yard there is a forsythia bush, not exceptionally large or handsome, that gives me as much pleasure as one of those wonderful tulip beds of which the Boston city gardeners make so much account. Are a million tulips, all of one color, crowded tightly together and bordered by a row of other tulips, all of another color, really so much more beautiful than a hun- 
dred or two, of various tints, loosely and naturally disposed? I ask the question without answering it, though I could answer it easily enough, so far as my own taste is concerned.

Already there is much to admire in the wild garden. Spice-bush blossoms have come and gone, and now the misty shad-blow is beginning to whiten all the hedges and the borders of the wood, while sassafras trees have put forth pretty clusters of yellowish flowers for the few that will come out to see them. Sun-bright, cold-footed cowslips still hold their color along shaded brooks. "Marsh marigolds," some critical people tell us we must call them. That is a good name, too; but the flowers are no more marigolds than cowslips, and with or without reason (partly, it may be, because my unregenerate nature resents the "must"), I like the word I was brought up with. Anemones and violets are becoming plentiful, and the first columbines already swing from the clefts of outcropping ledges. With them one is almost certain to find the saxifrage. The two are fast friends, though very unlike; the 
columbine drooping and swaying so gracefully, its honey-jars upside down, the saxifrage holding upright its cluster of tiny white cups, like so many wine-glasses on a tray. Both are children's flowers, - an honorable class, - and have in themselves, to my apprehension, a kind of childish innocence and sweetness. If we picked no other blossoms, down in the Old Colony, we always picked these two - these and the nodding anemone and the pink lady's-slipper.

This showy orchid, by the way, I was pleased a year ago to see in bloom side by side with the trailing arbutus. One was near the end of its flowering season, the other just at the beginning, but there they stood, within a few yards of each other. This was in the Franconia Notch, at the foot of Echo Lake, where plants bloom when they can, rather than according to any calendar known to down-country people; where within the space of a dozen yards you may see the dwarf cornel, for example, in all stages of growth; here, where a snowbank stayed late, just peeping out of the ground, and there, in a sunnier spot, already in full bloom. 
In May the birds come home. This is really what makes the month so short. There is no time to see half that is going on. In this town alone it would take a score of good walkers, good lookers, and good listeners to welcome all the pretty creatures that will this month return from their winter's exile. Some came in March, of course, and more in April; but now they are coming in troops. It is great fun to see them; a pleasure inexpressible to wake in the morning, as I did this morning (May 8), and still lying in bed, to hear the first breezy fifing of a Baltimore oriole, just back over night after an eight months' absence. Birds must be lovers of home to continue living in a climate where life is possible to them only four months of the year.

Six days ago (May 2) a rose-breasted grosbeak gladdened the morning in a similar manner, though he was a little farther away, so that I did not hear him until I stepped out upon the piazza. I stood still a minute or two, listening to the sweet " rolling " warble, and then crossed the street to have a look at the rose color. It was just as bright as I remembered it. 
Golden warblers (summer yellow-birds) made their appearance on the last day of April. The next morning one had dropped into an ideal summering place, a bit of thicket beside a pond and a lively brook, - good shelter, good bathing, and plenty of insects, - and from the first moment seemed to have no thought of looking farther. I see and hear him every time I pass the spot. The same leafless thicket (but it will be leafy enough by and by) is now inhabited by a catbird. I found him on the 6th, already much at home, feeding, singing, and mewing. Between him and his small, high-colored neighbor there is no sign of rivalry or illfeeling; but if another catbird or a second warbler should propose settlement in that clump of shrubbery, I have no doubt there would be trouble.

May-day brought me the yellow-throated vireo, the parula warbler, the white-throated sparrow, and the least flycatcher, the last two pretty late, by my reckoning. On the $2 d$ came the warbling vireo, the veery, - a single silent bird, the only one I have yet seen, - the kingbird, the Maryland yellow- 
throat, the oven-bird, and the chestnut-sided warbler, in addition to the grosbeak before mentioned. Then followed a spell of cold, unfavorable weather, and nothing more was listed until the 6 th. That day I saw a Nashville warbler, - several days tardy, a catbird, and a Swainson thrush. On May 7, I heard my first prairie warbler, and today has brought the oriole, the wood thrush, one silent red-eyed vireo (it is good to know that this voluble "preacher" can be silent), and the redstart. It never happened to me before, I think, to see the Swainson thrush earlier than the wood. That I have done so this season is doubtless the result of some accident, on one side or the other. The Swainson was a little ahead of his regular schedule, I feel sure; but on the other hand, it may almost be taken for granted that a few wood thrushes have been in the neighborhood for several days. The probability that any single observer will light upon the very first silent bird of a given species that drops into a township must be slight indeed. What we see, we tell of ; but that is only the smallest part of what happens. 
Some of our winter birds still go about in flocks, notably the waxwings, the goldfinches, and the purple finches. Two days ago I noticed a goldfinch that was almost in full nuptial dress; as bright as he ever would be, I should say, but with the black and the yellow still running together a little here and there. Purple finches are living high - in two senses - just at present, feeding on the pendent flower-buds of tall beech trees. A bunch of six or eight that I watched the other day were literally stuffing themselves, till I thought of turkeys stuffed with chestnuts. Their capacity was marvelous, and I left them still feasting. All the while one of them kept up a happy musical chatter. There is no reason, I suppose, why a poet should not be a good feeder. 


\section{A FULL MIGRATION}

ONE of my friends, a bird lover like myself, used to complain that by the end of May he was worn out with much walking. His days were consumed at a desk, - " the cruel wood," as Charles Lamb called it, — but so long as migrants were passing his door he could not help trying to see them. Morning and night, therefore, he was on foot, now in the woods, now in the fields, now in shaded by-roads, now in bogs and swamps. To see all kinds of birds, a man must go to all kinds of places. Sometimes he trudged miles to visit a particular spot, in which he hoped to find a particular species. Before the end of the month he must have one hundred and twenty or one hundred and twentyfive names in his "monthly list;" and to accomplish this, much leg-work was necessary.

I knew how to sympathize with him. Short as May is, - too short by half, - I 
have before now felt something like relief at its conclusion. Now, then, I have said, the birds that are here will stay for at least a month or two, and life may be lived a little more at leisure.

This year, ${ }^{1}$ by all the accounts that reach me, the migration has been of extraordinary fullness. Only last night a man took a seat by me in an electric car and said, what for substance I have heard from many others, that he and his family, who live in a desir- ably secluded, woody spot, had never before seen so many birds, especially so many warblers.

How wiser men than myself explain this unusual state of things I do not know. To me it seems likely that the unseasonable cold weather caught the first large influx of May birds in our latitude, and held them here while succeeding waves came falling in behind them. The current was dammed, so to speak, and of course the waters rose.

Some persons, I hear, had strange experiences. I am told of one man who picked a black-throated blue warbler from a bush, 
as he might have picked a berry. I myself noted in New Hampshire, what many noted hereabouts, the continual presence of warblers on the ground. ' $T$ is an ill wind that blows nobody good, and our multitude of young bird students - for, thank Heaven, they are a multitude - had the opportunity of many years to make new acquaintances. A warbler in the grass is a comparatively easy subject.

After all, the beginners have the best of it. No knowledge is so interesting as new knowledge. It may be plentifully mixed with ignorance and error. Much of it may need to be unlearned. Young people living about me began to find scarlet tanagers early in April; one boy or girl has seen a scissor-tailed flycatcher, and orchard orioles seem to be fairly common; but at least new knowledge has the charm of freshness. And what a charm that is! - a morning rose, with the dew on it. The old hand may almost envy the raw recruit - the young woman or the boy, to whom the sight of a rose-breasted grosbeak, for instance, is like the sight of an angel from heaven, so strange, 
so new-created, so incredibly bright and handsome.

I love to come upon a group or a pair of such enthusiasts at work in the field, as I not seldom do; all eyes fastened upon a bush or a branch, one eager, low voice trying to make the rest of the company see some wonderful object of which the lucky speaker has eaught sight. "There, it has moved to that lower limb! Right through there! Don't you see it? Oh, what a beauty!"

I was down by the river the other afternoon. Many canoes were out, and presently I came to an empty one drawn up against the bank. A few steps more and I saw, kneeling behind a clump of shrubbery, a young man and a young woman, each with an operanglass, and the lady with an open notebook. "It's a redstart, is n't it? " I heard one of them say.

It was too bad to disturb them, but I hope they forgave a sympathetic elderly stranger, who, after starting toward them and then sidling off, finally approached near enough to suggest, with a word of apology, that per- 
haps they would like to see a pretty bunch of water thrushes just across the way, about the edges of the pool under yonder big willow. They seemed grateful, however they may have felt. "Water thrushes!" the young lady exclaimed, and with hasty "Thank you's," very politely expressed, they started in the direction indicated. It is to be hoped that they found also the furtive swamp sparrow, of whose presence the bashful intruder, in the perturbation of his spirits, forgot to inform them. If they did find it, however, they were sharp-eyed, or were playing in good luck.

I went on down the river a little way, and soon met three Irish-American boys coming out of a thicket at the water's edge. One of them lifted his cap. "Seen any good birds to-day?" he inquired. I answered in the affirmative, and turned the question upon its asker. Yes, he said, he had just seen a catbird and an oriole. I remarked that there were other people out on the same errand. "Yes," said he, pointing toward the brier thicket, "there's a couple down there now looking at 'em." Then I noticed a sec- 
ond empty canoe with its nose against the bank.

This was on a Saturday. Saturday afternoon and Sunday are busy people's days in the woods. For their sakes I am always glad to meet them there - bird students, flower pickers, or simple strollers; yet I have learned to look upon those times as my poorest, and to choose others so far as I can. One does not enjoy nature to great advantage at a picnic. There are woods and swamps of which on all ordinary occasions I almost feel myself the owner, but of which on Saturday and Sunday I have scarcely so much as a rambler's lease. This I have learned, however, - and I pass the secret on, - that the Sunday picnic does not usually begin till after nine o'clock in the forenoon.

When bird study becomes more general than it is now, as it ought to do, the community will perhaps find means - or, to speak more correctly, will use means, since there is no need of finding them - to restrain the present enormous overproduction of English sparrows, and so to give cer- 
tain of our American beauties a chance to live.

Two days ago I was walking through a tract of woodland, following the highway, when I noticed, to my surprise, a whitebreasted martin (tree swallow) just over my head. The next moment he fluttered before a hole in one of the big telegraph poles. His mate came out, and he alighted in the entrance, facing outward. And there he sat, while $I$ in my turn took a seat upon the opposite bank and fell to watching him. The light struck him squarely, and it was good to see his blue-purple crown and his bright black eye shining in the sun. He had nothing to do inside, it appeared, but was simply on guard in his mate's absence. Once he yawned. "She's gone a good while," he seemed to say. But he kept his post till she returned. Then, with a chirrup, he was off, and she dropped into the cavity out of sight.

All this was nothing of itself. But why should a pair of white-breasted martins, farm-loving, village-loving, house-haunting birds, a delight to the eye, and as innocent 
as they are beautiful - why should such birds be driven to seek a home in a telegraph pole in the woods? The answer was ready. I walked on, and by and by came to a village, young and I dare say thriving, but overrun from end to end with English sparrows, whose incessant clatter-

Soul-desolating strains - alas! too many -

filled my ears. Not a bluebird, not a tree swallow, nor, to all appearance, any place for one.

And so it is generally. One of my fellow townsmen, however, has an estate which forms a bright exception. There one sees bluebirds and martins. Year after year, punctual as the spring itself, they are back in their old places. And why? Because the owner of the estate, by a little shooting, mercifully persistent and therefore seldom necessary, keeps the English sparrows out. My thanks to him. His is the only colony of martins anywhere in my neighborhood. 


\section{A FAVORITE ROUND}

AfTer three days of heat, a cool morning. I take an electric car, leave it at a point five miles away, and in a semicircular course come round to the track again a mile or two nearer home. This is one of my favorite walks, such as every stroller finds for himself, affording a pleasant variety within comfortable distance.

First I come to a plain on which are hayfields, gardens, and apple orchards ; an open, sunny place where, in the season, one may hope to find the first bluebird, the first vesper sparrow, or the first bobolink. A spot where things like these have happened to one has henceforth a charm of its own. Memory. walks beside us, as it were, and makes good all present deficiencies.

I am hardly here this morning before the tiny, rough voice of a yellow-winged sparrow reaches me from a field in which the new- 
mown grass lies in windrows. Grass or stubble, he can still be happy, it appears. The grasshopper sparrow - to give him his better name - is one of the quaintest of songsters, his musical effort being more like an insect's than a bird's; yet he is as fully inspired, as completely absorbed in his work, to look at him, as any mockingbird or thrush. I watched one a few days ago as he sat at the top of a dwarf pear tree. How seriously he took himself! No "minor poet" of a human sort ever surpassed him in that respect; head thrown back, and bill most amazingly wide open, all for that ragged thread of a tune, which nevertheless was decidedly emphatic and could be heard a surprisingly long distance. I smiled at him, but he did not mind. When minor poets cease writing, then, we may guess, the grasshopper sparrow will quit singing. Far be the day. To be a poet is to be a poet, and distinctions of major and minor are of trifling consequence. The yellow-wing counts with the savanna, but is smaller and has even less of a voice. Impoverished grass fields are his favorite breeding-places, and he is generally a colonist. 
This morning (it is July 10) the vesper sparrow is singing here also, with the song sparrow and the chipper. And while I am listening to them — but mainly to the vesper - the sickle stroke (as I believe Mr. Burroughs calls it) of a meadow lark cuts the air. It is a good concert, vesper sparrow and lark going most harmoniously together; and to make it better still, a bobolink pours out one copious strain. Him I am especially glad to hear. After the grass is cut one feels as if bobolink days were over.

However, the grass is not all cut yet. I hear the rattle of a distant mowing-machine as I walk, and by and by come in sight of a man swinging a scythe. That is the poetry of farming - from the spectator's point of view; and I think from the mower's also, when he is cutting his own grass and is his own master. I like to watch him, at all events. Every motion he makes is as familiar to me as the swaying of branches in the wind. How long will it be, I wonder, before young people will be asking their seniors what a seythe was like, 
and how a man used it? Pictures of it will look odd enough, we may be sure, after the thing itself is forgotten.

While I am watching the mower (now he pauses a moment, and with the blade of his scythe tosses a troublesome tangle of grass out of his way, with exactly the motion that I have seen other mowers use a thousand times; but I look in vain for him to put the end of the snathe to the ground, pick up a handful of grass, and wipe down the blade) - while I am watching him a bluebird breaks into song, and a kingbird flutters away from his perch on a fence-wire. After all, the glory of a bird is his wings; and the kingbird knows it. In another field men are spreading hay - with pitchforks, I mean; and that, too, is poetry. In truth, by the old processes, hay could not be made except with graceful motions, unless it were by a novice, some man from the city or out of a shop. A green hand with a rake, it must be confessed, is a subject for laughter rather than for rhymes. The secret of graceful raking is like the secret of graceful writing, - a light touch. 
Raspberries and thimbleberries are getting ripe (they do not need to be "dead ripe," thimbleberries especially, for an old country boy), and meadow-sweet and mullein are in bloom. Hardhack, standing near them, has not begun to show the pink.

Now I turn the corner, leaving the farms behind, and as I do so I bethink myself of a bed of yellow galium just beyond. It ought to be in blossom. And so it is - the prettiest sight of the morning, and of many mornings. I stand beside it, admiring its beauty and inhaling its faint, wholesomely sweet odor. Bedstraw, it is called. If it will keep that fragrance, why should mattresses ever be filled with anything else? This is the only patch of the kind that I know, and I felicitate myself upon having happened along at just the right minute to see it in all its sweetness and beauty. Year after year it blooms here on this roadside, and nowhere else; millions of tiny flowers of a really exquisite color, yellow with much of green in it, a shade for which in my ignorance I have no name.

The road soon runs into a swamp, and I 
stop on the bridge. Swamp sparrows are trilling on either side of me - a spontaneous, effortless kind of music, like water running downhill. A phœbe chides me gently; passengers are expected to use the bridge to cross the brook upon, she intimates, not as a lounging-place, especially as her nest is underneath. Yellow bladderworts lift their pretty hoods above the slimy, black water, and among them lies a turtle, thrusting his head out to enjoy the sun. Once I see him raise a foreclaw and scratch the underside of his neck. The most sluggish and cold-blooded animal that ever lived must now and then be taken with an itching, I suppose.

Beyond the bridge the woods are full of white azalea (they are full of it now, that is to say, so long as the bushes are in blossom), but I listen in vain for the song of a Canadian warbler, whom I know to be living somewhere in its shadow. A chickadee, looking as if she had been through the wars, her plumage all blackened and bedraggled, makes remarks to me as I pass. The cares of maternity have spoiled her beauty, and perhaps ruffled her temper, for the time be- 
ing. A veery snarls, and a thrasher's resonant kiss makes me smile. If he knew it, he would smile in his turn, perhaps, at my "pathetic fallacy." The absence of music here, just where I expected it most confidently, is disappointing, but I do not stay to grieve over the loss. As the road climbs to dry ground again, I remark how close to its edge the rabbit-foot clover is growing. It is at its prettiest now, the grayish green heads tipped with pink. If it were as uncommon as the yellow bedstraw, perhaps I should think it quite as beautiful. I have known it since I have known anything ("pussies," we called it), but I never dreamed of its being a clover till I began to use a botany book. All the way along I notice how it cleaves to the very edge of the track. "Let me have the poorest place," it says. And it thrives there. Such is the inheritance of the meek.

Here in the pine woods a black-throated green warbler is dreaming audibly, and, better still, a solitary vireo, the only one I have heard for a month or more, sings a few strains, with that sweet, falling cadence of which he alone has the secret. From a 
bushy tract, where fire has blackened everything, a chewink speaks his name, and then falls to repeating a peculiarly jaunty variation of the family tune. Dignity is hardly the chewink's strong point. Now a field sparrow gives out a measure. There is an artist! Few can excel him, though many can make more show. Like the vesper sparrow, he has a gift of sweet and holy simplicity. And what can be better than that? Overhead, hurrying with might and main toward the woods, flies a crow, with four kingbirds after him. Perhaps he suffers for his own misdeeds; perhaps for those of his race. All crows look alike to kingbirds, I suspect.

This, and much beside, while I rest in the shade of a pine, taking the beauty of the clouds and listening to the wind in the treetops. The best part of every ramble is the part that escapes the notebook. 


\section{IN THE CAMBRIDGE SWAMP}

ONCE a year, at least, I must visit the great swamp in Cambridge, one of the institutions of the city, as distinctive, not to say as famous, as the university itself. It is sure to show me something out of the ordinary run (its courses in ornithology are said to be better than any the university offers); and even if $\mathrm{I}$ were disappointed on that score, I should still find the visit worth while for the sake of old times, and old friends, and the good things I remember. At the present minute I am thinking especially of that enthusiastic, wise-hearted, finely gifted, greatly lamented nature-lover, Frank Bolles, whom I met here for the first time one evening when it was too dark to see his face. We had come on the same errand, to watch the strange aerial evolutions of the April snipe. Who could have supposed then that he would be dead so soon, and the world so much the poorer? 
Now it is July. The tall swamp rosebushes are in full flower, here and there a clump, the morning sun heightening their beauty, though for the most part there is no getting near them without wading to the knees. More accessible, as well as more numerous, are the trailing morning-glory vines (Convolvulus sepium), with showy, trumpet-shaped, pink-and-white blossoms; and in one place I stop to notice a waterystemmed touch-me-not, or jewel-weed, from which a solitary frail-looking, orange-colored flower is hanging - the first of the year. What thousands on thousands will follow it; no meadow's edge or boggy spot will be without them. The pendent jewel makes me think of hummingbirds, which is another reason for liking to look at it. Years ago I used to plant some of its red and white congeners (balsams, we called them) in a child's garden. I wish I were a botanist; I am always wishing so; but I am thankful to know enough of the science to be able to recognize a few such relationships between native "weeds" and cultivated exotics. Somehow the weeds look less weedy for that 
knowledge; as the most commonplace of mortals becomes interesting to average humanity if it is whispered about that he is fourth cousin to the king. The world is not yet so democratic that anything, even a plant, can be rated altogether by itself.

The gravelly banks of the railroad, on which I go dry-shod through the swamp, are covered with a forest of chicory; a thrifty immigrant, tall, coarse, scraggy, awkward, homely, anything you will, but a great brightener of our American waysides on sunny midsummer forenoons. It attracts much notice, and presumably gives much pleasure, to judge by the number of persons who ask me its name. May the town fathers spare it! The bees and the goldfinches will thank them, if nobody else. Here I am interested to see that a goodly number of the plants - but not more than one in fifty, perhaps - bear full crops of pure white flowers; a rarity to me, though I am well used to pink ones. Gray's Manual, by the by, a Cambridge book, makes no mention of white flowers, while Britton and Brown's Illustrated Flora says nothing about 
a pink variety. In a multitude of books there is safety, or, if not quite that, something less of danger. The pink and the white flowers are reversions to former less highly developed states, I suppose, if certain modern theories are to be trusted. I have read somewhere that the acid of ants turns the blue of chicory blossoms to a bright red, and that European children are accustomed to throw the flowers into ant hills to watch the transformation. Perhaps some young American reader will be moved to try the experiment.

The best plants, however, those that I enjoy most for to-day, at all events, are the cat-tails. How they flourish! - "like a tree planted by the rivers of water." And how straight they grow! They must be among the righteous. We may almost say that they make the swamp. Certainly, when they are gone the swamp will be gone. Both kinds are here, the broad-leaved and the narrow-leaved, equally rank, though angustifolia has perhaps a little the better of the other in point of height. The two can be distinguished at a glance, and afar 
off, by a difference in color, if by nothing else. "Cat-tails" and "cat-tail flags," the Manual and the Illustrated Flora call them; but I was brought up to say " cat-o'-ninetails," with strong emphasis on the numeral, and am glad to find that more romanticsounding name recognized by the latest big dictionary. Not that the name has any particular appropriateness; but like my fellows, I have been trained to venerate a dictionary, especially an " unabridged," as hardly less sacred than the Bible, and am still much relieved whenever my own usage, past or present, happens to be supported by such authority.

Rankness is the swamp's note, we may say. Look at the spatter-dock leaves and the pickerel weed! The tropics themselves could hardly do better. And what a maze and tangle of vegetation! - as if the earth could produce more than the air could find room for. So much for plenty of water and a wholesome depth of black mud. One thinks of the scriptural phrase about paths that "drop fatness."

Ever since I arrived, the short, hurried, 
gurgling trill of the long-billed marsh wren has been in my ears. If I have been here an hour, I must have heard that sound five hundred times. Once only, and only for an instant, I saw one of the singers. I have not been on the watch for them, to be sure; but if it had been earlier in the season I should have seen them whether I tried to do so or not. It must be that the little aerial songflights, then so common and so cheerful to look at, are now mostly over.

In such a place, however, populous as it is, one does not expect to see many birds blackbirds being left out of the reckoning at any time. Swamp ornithology is mainly a matter of "earsight." Birds that live in cat-tail beds and button-bush thickets are very little on the wing. Here a least bittern may coo day after day, and season after season, and it will be half a lifetime before you see him do it. I have made inquiries far and near in the likeliest quarters, and have yet to learn, even at second hand, of any man who has ever had that good fortune. Once, for five minutes, I entertained a lively hope of accomplishing the feat myself, but the 
bird was too wary for me; and a miss is as good as a mile. No doubt I shall die without the sight.

So the Carolina rail will whistle and the Virginia rail call the pigs, but it will be a memorable hour when you detect either of them in the act. You will hear the sounds often enough; I hear them to-day; and much less frequently you will see the birds stepping with dainty caution along a favorite runway, or feeding about the edges of their cover. But to see them utter the familiar notes, that is another story.

This morning I see on the wing a night heron (so I call him, without professing absolute certainty), a bittern (flying from one side of the railroad tracks to the other), and a little green heron, but no rail of either species, although I sit still in favorable places - where at other times I have seen them - with exemplary patience. In hunting of this kind, patience must be mixed with luck. It pleases my imagination to think what numbers of birds there are all about me, each busy with its day's work, and not one of them visible for an instant, even by chance. 
I go to the top of a grassy mound, and seat myself where $I$ have a lengthwise view of a ditch. Here, ten years ago, more or less, I saw my first gallinule. We had heard his outeries for some days (I speak of myself and two better men), and a visiting New York ornithologist had told us that they were probably the work of a gallinule. They came always from the most inaccessible parts of the swamp, where it seemed hopeless to wade in pursuit of the bird, since we wished to see him alive; but turning the question over in my mind, I bethought myself of this low hilltop, with its command of an open stretch of water between a broad expanse of cat-tails and a wood. Hither I came, therefore. If there was any virtue in waiting, the thing should be done. And sure enough, in no very long time out paddled the bird, with those queer bobbing motions which I was to grow familiar with afterward - a Florida gallinule, with a red plate on his forehead. Again and again I saw him (patience was easy now), and when I had seen enough for that time - and was on my way back to the railway station, I met the foremost of 
New England ornithologists coming down the track. He was on the same hunt, and together we returned to the place I had left; and together we saw the bird. A week or two later he found the nest, and a Massachusetts record was established.

This, I say, was ten years ago. To-day there is no gallinule, or none for me. The best thing I hear, the most characteristically swampy, is the odd diminuendo whistle of a Carolina rail. "We are all here," he says; "you ought to come oftener." And I think I will. 


\section{A QUIET AFTERNOON}

AFTER running hither and thither in search of beauty or novelty, try a turn in the nearest wood. So my good genius whispered to me just now; and here I am. I believe it was good advice.

This venerable chestnut tree, with its deeply furrowed, shadow-haunted, lichencovered bark of soft, lovely grays and grayish greens, is as stately and handsome as ever. How often I have stopped to admire it, summer and winter, especially in late afternoon, when the level sunlight gives it a beauty beyond the reach of words. Many a time I have gone out of my way to see it, as I would have gone to see some remembered landscape by a great painter.

There is no feeling proud in such company. Anything that can stand still and grow, filling its allotted place and contented to fill it, is enough to put our futile human 


\section{A QUIET AFTERNOON}

restlessness to the blush. The wind has long ago blown away some of its branches, but it does not mind. It is busy with its year's work. I see the young burrs, no bigger than the end of my little finger. When the nuts are ripe the tree will let them fall and think no more about them. How different from a man! When he does a good thing, if by chance he ever does, he must put his hands behind his ears in hopes to hear somebody praising him. Mountains and trees make me humble. I feel like a poor relation.

The pitch-pines are no longer at their best estate. They are brightest when we need their brightness most, in late winter and early spring. This year, at least, the summer sun has faded them badly; but their fragrance is like an elixir. It is one of the glories of pine needles, one of the things in which they excel the rest of us, that they smell sweet, not "in the dust" exactly, but after they are dead.

A nuthatch in one of the trees calls "Tut, tut, tut," and is so near me that I hear his claws scratching over the dry bark. A busy 
and cheerful body. Just beyond him a scarlet tanager is posed on a low, leafless twig. Like the pine leaves, he looks out of condition. I am sure I have seen brighter ones. $\mathrm{He}$ is silent, but his mate, somewhere in the oak branches over my head, keeps up an emphatic chip-cherr, chip-cherr. Yes, I see her now, and the red one has gone up to perch at her side. She cocks her head, looking at me first out of one eye and then out of the other, and repeats the operation two or three times, like a puzzled microscopist squinting at a doubtful specimen; and all the while she continues to call, though I know nothing of what she means. Once her mate approaches too near, and she opens her bill at him in silence. He understands the sign and keeps his distance. I admire his spirit. It is better than taking a city.

The earliest of the yellow gerardias is in . bloom, and a pretty desmodium, also ( $D$. nudiflorum), with a loose raceme of small pink flowers, like miniature sweet-pea blossoms, on a slender leafless stalk. These are in the wood, amidst the underbrush. As I come out into a dry, grassy field I find the 


\section{A QUIET AFTERNOON}

meadow-beauty; an odd creature, with a tangle of long stamens; bright-colored, showy in its intention, so to speak, but rather curious than beautiful, in spite of its name; especially because the petals have not the grace to fall when they are done, but hang, withered and discolored, to spoil the grace of later comers. The prettiest thing about it all, after the freshly opened first flower, is the urn-shaped capsule. That, to me, is of really classic elegance.

Now I have crossed the road and am seated on a chestnut stump, with my back against a tree, on the edge of a broad, rolling, closely cropped cattle-pasture, a piece of genuine New England. Scattered loosely over it are young, straight, slender-waisted, shoulder-high cedars, and on my right hand is a big patch of hardhack, growing in tufts of a dozen stalks each, every one tipped with an arrow-head of pink blossoms. The whole pasture is full of sunshine. Down at the lower end is a long, narrow, irregular-shaped pond. I cannot see it because of a natural hedge against the fence-row on my left; but somehow the landscape takes an added beauty 


\section{THE CLERK OF THE WOODS}

from the water's presence. The truth is, perhaps, that I do see it.

High overhead a few barn swallows and chimney swifts are scaling, each with happysounding twitters after its kind. A jay screams, but so far off as merely to emphasize the stillness. Once in a while a song sparrow pipes; a cheerful, honest voice. When there is nothing better to do I look at the hardhack. The spiræas are a fine set; many of them are honored in gardens; but few are more to my liking; after all, than this old friend (and enemy) of my boyhood. Whether it is really useful as an herb out of which to make medicinal " tea "I feel no competency to say, though I have drunk my share of the decoction. It is not a virulent poison: so much I feel reasonably sure of. Hardhack, thoroughwort, and pennyroyal, - with the $o$ left out, - these were the family herbalist's trinity in my day. Now, in these better times of pellets and homœopathic allopathy, children hardly know what medicine-taking means. We remember, we of an older generation. "Pinch your nose and swallow it, and I will give you a cent." Does that 


\section{A QUIET AFTERNOON}

sound vulgar in the nice ears of modern readers? Well, we earned our money.

Now an oriole's clear August fife is heard. A short month, and he will be gone. And hark! A most exquisite strain by one of the best of field sparrows. I have never found an adjective quite good enough for that bit of common music. I believe there is none. Nor can I think of any at this moment with which to express the beauty of this summer afternoon. Fairer weather was never seen in any corner of the world. Four crows fly over the field in company. The hindmost of them has a hard time with a redwing, which strikes again and again. "Give it to him!" say I. Between crow and man I am for the crow; but between the crow and the smaller bird I am always for the smaller bird. Whether I am right or wrong is not the question here. This is not my day for arguing, but for feeling.

How pretty the hardhack is! Though it stands up rather stiff, it feels every breath of wind. Its beauty grows on me as I look, which is enough of itself to make this a profitable aftermoon. There is no beauty so welcome as new beauty in an old friend. 
A kingbird, one of two or three hereabout, comes to sit on a branch over my head. He is full of twitters, which sound as if they might be full of meaning; but there is no interpreter. He, too, like the oriole, is on his last month. I have great respect for kingbirds. A phœbe shows herself in the hedge, flirting her tail airily as she alights. "Pretty well, I thank you," she might be saying. Every kind of bird has motions of its own, no doubt, if we look sharply enough. The-phœbe's may be seen of all men.

I had meant to go out and sit awhile under the spreading white oak yonder, on the upper side of the pasture, near the huckleberry patches; but why should I? Well enough is well enough, I say to myself; and it sounds like good philosophy, in weather like this. It may never set the millpond on fire; but then, I don't wish to set it on fire.

And although I go on mentioning particulars, a flower, a bird, a bird's note, it is none of these that I am really enjoying. It is the day - the brightness and the quiet, 
and the comfort of a perfect temperature. Great is weather. No man is to blame for talking about it, unIess his talk is twaddle. Out-of-door people know that few things are more important. A quail's whistle, a thought too strenuous, perhaps, for such an hour, - a breezy quoit, - breaks my disquisition none too soon; else I might have been brought in guilty under my own ruling.

As I get over the fence, on my start homeward, I notice a thrifty clump of chokecherry shrubs on the other side of the way, hung with ripening clusters, every cheriy a jewel as the sun strikes it. They may hang " for all me," as schoolboys say. My country-bred taste is pretty catholic in matters of this kind, but it extends not to chokecherries. They should be eaten by campaign orators as a check upon fluency. 


\section{POPULAR WOODPECKERS}

There are two birds in Newton, the present summer, that have perhaps attracted more attention than any pair of Massachusetts birds ever attracted before; more, by a good deal, I imagine, than was paid to a pair of crows that, for some inexplicable reason, built a nest and reared a brood of young a year ago in a back yard on Beacon Hill, in Boston. I refer to a pair of redheaded woodpeckers that have a nest (at this moment containing young birds nearly ready to fly) in a tall dead stump standing on the very edge of the sidewalk, like a lamp-post. The road, it should be said, is technically unfinished; one of those "private ways," not yet " accepted" by the city and therefore legally "dangerous," though in excellent condition and freely traveled. If the birds had intended to hold public receptions daily, - as they have done with- 
out intending it, - they could hardly have chosen a more convenient spot. The stump, which is about twenty-five feet in height, stands quite by itself in the middle of a small open space, with a wooded amphitheatrical knoll at its back, while on the other side it is overlooked by the windows of several houses, the nearest almost within stone's throw. So conspicuous is it, indeed, that whenever I go there, as I do once in two or three days, to see how matters are coming on, I am almost sure to see the birds far in advance of my arrival.

They are always there. I heard of them through the kindness of a stranger, on the 26th of June. His letter reached me (in Boston) at two o'clock in the afternoon, and at half past three I was admiring the birds. It cannot be said that they welcomed my attentions. From that day to this they have treated me as an intruder. "You have stayed long enough." "We are not at home to-day." "Come now, old inquisitive, go about your business." Things like these they repeat to me by the half hour. Then, in audible asides, they confide to each other 
what they think of me. "Watch him," says one at last. "I must be off now after a few grubs." And away she goes, while her mate continues to inform me that I am a busybody, a meddler in other birds' matters, a common nuisance, a duffer, and everything else that is disreputable. All this is unpleasant. I feel as I imagine a baseball umpire feels when the players call him a "gump" and the crowd yells " robber;" but like the umpire, I bear it meekly and hold my ground. A good conscience is a strong support.

In sober truth I have been scrupulously careful of the birds' feelings; or, if not of their feelings, at least of their safety. I began, indeed, by being almost ludicrously careful. The nest was a precious secret, I thought. I must guard it as a miser guards his treasure. So, whenever a foot-passenger happened along the highway at my back, I made pretense of being concerned with anything in the world rather than with that lamp-post of a stump. What was Hecuba to me, or I to Hecuba? I pretty soon learned, however, that such precautions 
were unnecessary. The whole town, or at least the whole neighborhood, was aware of the birds' presence. Every school-teacher in the city, one man told me, had been there with his or her pupils to see them. So popular is ornithology in these modern days. He had seen thirty or forty persons about the place at once, he said, all on the same errand. "Look at the bank there," he added. "They have worn it smooth by sitting on it."

I have not been fortunate enough to assist at any such interesting "function," but I have had plenty of evidence to prove the truth of what I said just now - that the birds and their nest have become matters of common knowledge. On my third visit, just as I was ready to come away, a boy turned the corner on a bicycle, holding his younger sister in front of him.

"Are they here?" he inquired as he dismounted.

"Who?" said I.

"The red-headed woodpeckers," he answered.

He had known about the nest for some 
weeks. Oh, yes, everybody knew it. Soand-so found it ( $I$ forget the name), and pretty soon it was all over Newtonville. A certain boy, whose wretched name also I have forgotten, had talked about shooting one of the birds; he could get a dollar and a half for it, he professed; but policeman Blank had said that a dollar and a half would n't do a boy much good if he got hold of him. He - my informant, a bright-faced, manly fellow of eleven or twelve - had brought his younger sister down to see the birds. He thought they were very handsome. "There!" said he, as one of them perched on a dead tree near by, "look!" and he knelt behind the little girl and pointed over her shoulder till she got the direction. After all, I thought, a boy is almost as pretty as a woodpecker. His father and mother were Canadians, and had told him that birds of this kind were common where they used to live. Then he lifted his sister upon the wheel, jumped up behind her, and away they trundled.

At another time an older boy came along, also on a bicycle, and stopped for a minute's 
chat. $\mathrm{He}$, too, was in the secret, and had been for a good while. "Pretty nice birds," his verdict was. And at a later visit a man with his dog suddeniy appeared. "Handsome, are n't they?" he began, by way of good-morning. He had seen one of them as long ago as when snow was on the ground, but he did n't discover the nest. He was looking in the wrong place. Since then he had spent hours in watching the birds, and believed that he could tell the female's voice from the male's. "There!" said he; "that's the mother's call." He was acquainted with all the birds, and could name them all, he said, simply by their notes; and he told me many things about them. There were grosbeaks here. Did I know them? And tanagers, also. Did I know them? And another bird that he was especially fond of ; a beautiful singer, though it never sang after the early part of the season; the indigo-bird, its name was. Did I know that?

As will readily be imagined, we had a good session (one does n't fall in with so congenial a spirit every day in the week), though it ran a little too exclusively to questions and 
answers, perhaps; for I, too, am a Yankee. He was the man who told me about the throngs of sightseers that came here. The very publicity of the thing had been the birds' salvation, he was inclined to believe. The entire community had taken them under its protection, and with so many windows overlooking the place, and the police on the alert ( $I$ had noticed a placard near by, signed by the chief, laying down the law and calling upon all good citizens to help him enforce it), it would have been hard for anybody to meddle with the nest without coming to grief. At all events, the birds had so far escaped molestation, and the young, as I have said, would soon be on the wing. One of them was thrusting its full-grown, wide-awake, eager-looking, mouse-colored head out of the aperture as we talked.

"But why so much excitement over a family of woodpeckers?" some reader may be asking. Rarity, my friend ; rarity and brilliant feathers. So far as appears from the latest catalogue of Massachusetts birds, this Newton nest is one of a very small number ever found in the State, and the very first 
one ever recorded from the eastern half of it. 1 Put that fact with the further one that the birds are among the showiest in North America, real marvels of beauty, - splendid colors, splendidly laid on, - and it is plain to see why a city full of nature lovers should have welcomed this pair with open arms and watched over their welfare as one watches over the most honored of guests. For my part, I should not think it inappropriate if the mayor were to order the firing of a salute and the ringing of bells on the happy morning when the young birds take wing. Tons of gunpowder have been burnt, before now, with less reason.

1 The formal record will be found in the $A u k$, vol. xviii. p. 394. 


\section{LATE SUMMER NOTES}

ON this bright morning I am passing fields and kitchen gardens that I have not seen since a month ago. Then the fields were newly mown stubble-fields, such as all men who knew anything of the luxury of a barefooted boyhood must have in vivid remembrance. (How gingerly, with what a sudden slackening of the pace, we walked over them, if circumstances made such a venture necessary, - in pursuit of a lost ball, or on our way to the swimming-hole, - setting the foot down softly and stepping high! I can see the action at this minute, as plainly as I see yonder fence-post.) Now the first thing that strikes the eye is the lively green of the aftermath. It looks as soft as a velvet carpet. I remember what I used to hear in haying time, that cattle like the second erop best. I should think they would.

Grass is man's patient friend. Directly 
or indirectly, we may say, he subsists upon it. Nay, the Scripture itself declares as much, in one of its most familiar texts. It is good to see it so quick to recover from the cruel work of the scythe, so responsive to the midsummer rains, its color so deep, its leaves so full of sap. It is this spirit of hopefulness, this patience under injury, that makes shaven lawns possible.

As to the beauty of grass, no man appreciates it, I suppose, unless he has lived where grass does not grow. "When I go back to New England," said an exile in Florida, "I will ask for no garden. Let me have grass about the house, and I can do without roses."

The century ends with an apple year ; and every tree is in the fashion. The old, the decrepit, the solitary, not one of them all but got the word in season; as there is no woman in Christendom but learns somehow, before it is too late, whether sleeves are to be worn loose or tight. Along the roadside, in the swamp, in the orchard, everywhere the story is the same. Apple trees are all freemasons. This hollow shell of a trunk, with one last battered limb keeping it alive, received its cue with the rest. 
In the orchard, where the trees are younger and more pliable, a man would hardly know them for the same he saw there in May and June; so altered are they in shape, so smoothly rounded at the top, so like Babylonian willows in the droop of the branches. Baldwins are turning red - greenish red and russets are already rusty. "Yes," says the owner of the orchard, "and much good will it do me." Apples are an "aggravating crop," he declares. "First there are none; and then there are so many that you cannot sell them." Human nature is never satisfied; and, for one, I think it seldom has reason to be.

A bobolink, which seems to be somewhere overhead, drops a few notes in passing. " $\mathrm{I}$ am off," he says. " "Sorry to go, but I know where there is a rice-field." From the orchard come the voices of bluebirds and kingbirds. Not a bird is in song; and what is more melancholy, the road and the fields are thick with English sparrows.

Now I stop at the smell of growing corn, which is only another kind of grass, though the farmer may not suspect the fact, and 
perhaps would not believe you if you told him of it; more than he would believe you if you told him that clover is not grass. He and his cow know better. A queer set these botanists, who get their notions from books! Corn or grass, here grow some acres of it, well tasseled (" all tosselled out"), with the wind stirring the leaves to make them shine. Does the odor, with which the breeze is loaded, come from the blossoms, or from the substance of the plant itself? A new question for me. I climb the fence and put my nose to one of the tassels. No, it is not in them, I think. It must be in the stalk and leaves; and $I$ adopt this opinion the more readily because the odor itself - the memory of which is part of every country boy's inheritance - is like that of a vegetable rather than of a flower, a smell rather than a perfume. I seem to recall that the stalk smelled just so when we cut it into lengths for cornstalk fiddles; and the nose, as everyone must have remarked, has a good memory, for the reason, probably, that it is so near the brain.

I turn the corner, and go from the garden 
to the wild. First, however, I rest for a few minutes under a wide-branching oak opposite the site of a vanished house. You would know there had been a house here at some time, even if you did not see the cellar-hole, by the old maid's pinks along the fence. How fresh they look! And how becomingly they blush ! They are worthy of their name. Age cannot wither them. Less handsome than carnations, if you will, but faithful, home-loving souls; not requiring to be waited upon, but given rather to waiting upon others. Like mayweed and catnip, they are what I have heard called "folksy plants;" though on second thought I should rather say " homey." There is something of the cat about them; a kind of local constancy; they stay by the old place, let the people go where they will. Probably they would grow in front of a new house, - even a Queen Anne cottage, so called, - if necessity were laid upon them, but who could imagine it? It would be shameful to subject them to such indignity. They are survivals, livers in the past, lovers of things as they were, charter members, I should say, of the Society of Colonial Dames. 
As I come to the edge of the swamp I see a leaf move, and by squeaking draw into sight a redstart. The pretty creature peeps at me furtively, wondering what new sort of man it can be that makes noises of that kind. To all appearance she is very desirous not to be seen; yet she spreads her tail every few seconds so as to display its bright markings. Probably the action has grown to be habitual and, as it were, automatic. A bird may be unconsciously coquettish, I suppose, as well as a woman or a man. It is a handsome tail, anyhow.

Somewhere just behind me a red-eyed vireo is singing in a peculiar manner; repeating his hackneyed measure with all his customary speed, - forty or fifty times a minute, - but with no more than half his customary voice, as if his thoughts were elsewhere. I wish he would sing so always. It would be an easy way of increasing his popularity.

Not far down the road are three roughly dressed men, — of the genus tramp, if I read the signs aright, — coming toward me; and I notice with pleasure that when they reach 
the narrow wooden bridge over the brook they turn aside, as by a common impulse, to lean over the rail and look down into the water. When I get there I shall do the same thing. So will every man that comes along, unless he happens to be on " business."

Running water is one of the universal parables, appealing to something primitive and ineradicable in human nature. Day and night it preaches - sermons without words. It is every man's friend. The most stolid find it good company. For that reason, largely, men love to fish. They are poets without knowing it. They have never read a line of verse since they outgrew Mother Goose; they never consciously admire a landscape; they care nothing for a picture, unless it is a caricature, or tells a story; but they cannot cross moving water without feeling its charm.

Well, in that sense of the word, I too am a poet. The tramps and $I$ have met and passed each other, and I am on the bridge. The current is almost imperceptible (like the passage of time), and the black water 
is all a tangle of cresses and other plants. Lucky bugs dart hither and thither upon its surface, quick to start and quick to stop (quick to quarrel, also, - like butterflies, - so that two of them can hardly meet without a momentary set-to), full of life, and, for anything that I know, full of thought; true poets, perhaps, in ways of their own; for why should man be so narrow-minded as to assume that his way is of necessity the only one?

On either side of the brook, as it winds through the swamp, are acres of the stately Joe Pye weed, or purple boneset, one of the tallest of herbs. I am beginning to think well of its color, - which is something like what ladies know as "crushed strawberry," if I mistake not, - though I used to look upon it rather disdainfully and call it faded. The plant would be better esteemed in that regard, I dare say, if it did not so often invite comparison with the cardinal flower. I note it as one of the favorites of the milkweed butterfly.

Here on the very edge of the brook is the swamp loosestrife, its curving stems all reach- 
ing for the water, set with rosy bloom. My attention is drawn to it by the humming of bees, a busy, contented, content-producing sound. How different from the hum of the factory that I passed an hour ago, through the open windows of which I saw men hurrying over " piece-work," every stroke like every other, every man a machine, or part of a machine, rather, for doing one thing. I wonder whether the dreariness of the modern "factory system" may not have had something to do with the origin and rapid development of our nineteenth-century breed of peripatetic thieves and beggars.

Above the music of the bees I hear, of a sudden, a louder hum. " A hummingbird," I say, and turn to look at a jewel-weed. Yes, the bird is there, trying the blossoms one after another. Then she drops to rest upon an alder twig (always a dead one) directly under my nose, where I see her darting out her long tongue, which flashes in the sunlight. I say "she." She has a whitish throat, and is either a female or a male of the present season. Did any one ever see a hummingbird without a thrill of pleasure? Not I. 
As I go on I note, half sadly, half gladly, some tokens of waning summer; especially a few first blossoms of two of the handsomest of our blue asters, laevis and patens. Soon the dusty goldenrod will be out, and then, whatever the almanac-makers may say, autumn will have come. Every dry roadside will publish the fact. 


\section{WOOD SILENCE}

THE scarcity of birds and bird music, of which I spoke a week ago, still continues. The ear begins to feel starved. A tanager's chip-cherr, or the prattle of a company of chickadees, is listened to more eagerly than the wood thrush's most brilliant measures were in June and July. Since September came in (it is now the 8th) I have heard the following birds in song: robins, half a dozen times, perhaps, in snatches only; a Maryland yellow-throat, once; warbling vireos, occasionally, in village elms; yellowthroated vireos, rarely, but more frequently than the last; a song sparrow (only one!), amusing himself with a low-voiced, inarticulate warble, rather humming than singing; an oriole, blowing a few whistles, on the 4 th ; a phœbe, on a single occasion ; wood pewees, almost daily, oftener than all the foregoing species together. 
Except a single water thrush, on the first day of the month, I have seen no land bird that could be set down with certainty as a migrant, and in the eight days I have listed but thirty-seven species. And of this number twelve are represented in my notes by a single individual only. My walks have been short, it is fair to say, but they have taken me into good places. I could spin a long chapter on the birds I have not seen; but perhaps the best thing I could do, writing merely as an ornithologist, would be to make the week's record in two words: "No quorum."

My last hummingbird (but I hope for others before the month ends) was seen on the $2 \mathrm{~d}$. He was about a bed of tall cannas in a neighbor's dooryard, thrusting his tongue into the flowers, one after another, and I went near and focused my opera-glass upon him, taking my fill of his pretty feathers and prettier movements. It was really the best music of the week. The sun was on his emerald back and wings, making them shine.

One thing that pleased me, as it always does, was his address in flying backwards. 
Into the flower he would dart, stay a longer or shorter time, as he found occasion, and then like a flash draw out and back away, his wings all the while beating themselves to a film of light. I wonder if any other of our common hovering birds - the kingbird, for example, or the kingfisher - can match the hummer in this regard.

A second thing that interested me was his choice of blossoms. My neighbor's canna bed is made up in about equal parts of two kinds of plants, one with red blossoms, the other with yellow. The hummer went to the red flowers only. He must have probed a hundred, I should say. As for the yellow ones, he seemed not to know they were there. Now, was not this a plain case of color preference? It looked so, surely; but I remembered that hummingbirds are persistent haunters of the yellow blossoms of the jewelweed, and concluded that something besides a difference of color must account for what appeared to be this fellow's well-considered line of conduct. It is hard work, but as far as possible, let us abstain from hasty generalizations. 
There is no music sweeter than wood silence. I am enjoying it now. It is not strictly silence, though it is what we call by that name. There is no song. No one speaks. The wind is not heard in the branches. But there is a nameless something in the air, an inaudible noise, or an audible stillness, of which you become conscious if you listen for it; a union of fine sounds, some of which, as you grow inwardly quiet, you can separate from the rest - beats of distant crickets, few and faint, and a hum as of tiny wings. Now an insect passes near, leaving a buzz behind him, but for a second only. Then, before you can hear it, almost, a frog out in the swamp yonder has let slip a quick, gulping, or string-snapping syllable. Once a small bird's wings are heard, just heard and no more. Far overhead a goldfinch passes, with rhythmic calls, smooth and soft, not so much sounds as a more musical kind of silence.

The morning sun strikes aslant through the wood, illuminating the trunks of the trees, especially a cluster of white birches. A lovely sisterhood! I can hardly take my 
eyes from them. In general all the leaves are motionless, but now and then a tree, or it may be a group of two or three at once, is jostled for an instant by a touch too soft for my coarser human apprehension. "Dee-dee," says a titmouse; "Here," answers a flicker. But both speak under their breath, as if they felt the spell of the hour. Listen! was that a hyla or a bird? There is no telling, so elusive and so distant-seeming was the sound. And anon it has ceased altogether.

Now, for the smallest fraction of a second, I see the flash of a moving shadow. The flicker's, perhaps. Yes, for presently he calls as in spring, but only for four or five notes. If it were April, with the vernal inspiration in his throat, there would be four or five times as many, and all the woods would be ringing. And now the breeze freshens, and the leaves make a chorus. No thrush's song could be sweeter. It is not a rustle. There is no word for it, unless we call it a murmur, a rumor. Even while we are trying to name it, it is gone. Leaves are true Friends, they speak only as the spirit moves. "Wicker, wicker," says the woodpecker, and his voice is in perfect tune with the silence. 
How still and happy the boulders look, with friendly bushes and ferns gathered about them, and parti-colored lichens giving them tones of beauty! Men call them dead. "Dead as a stone," has even passed into a proverb. "Stone dead," we say. But I doubt. They would smile, inwardly, I think to hear us. We have small idea, the wisest of us, what we mean by life and death. Men who hurry to and fro, scraping money together or chasing a ball, consider themselves alive. The trees, and even the stones, know better.

Yes, that is a crow, cawing; but far, far off. Distance softens sound as it softens the landscape, and as time, which is only another kind of distance, softens grief. A cricket at my elbow plays his tune, irregularly and slowly. The low temperature slackens his tempo. Now he is done. There is only the stirring of leaves. Some of the birch leaves, I see, are already turning yellow, and once in a while, as the wind whispers to one of them, it lets go its hold and drops. "Good-by," I seem to hear it say; "my summer is done." How tenderly the 
air lets it down, as loving arms lower a child to its burial. Yet the trees are still happy. And so am I. The wood has blessed me. I have sensations, but no thoughts. It is for this that I have been sitting here at this silent concert. I wish for nothing. The best that such an hour can do for us is to put us into a mood of desirelessness, of complete passivity; such a mood as mystics covet for a permanent possession; a state of surrender, selflessness, absorption in the infinite. I love the feeling. All the trees have it, I think.

So I sit in their shadow, my eyes returning again and again to those dazzling white birch boles, where loose shreds of filmy bark twinkle as the breeze and the sunlight play upon them. Once two or three chickadees come into the branches over my head and whisper things to each other. Very simple their utterances sound, but perhaps if $I$ could understand them I should know more than all the mystics. 


\section{SOUTHWARD BOUND}

Although it is the 20th of September, the autumnal migration of birds, as seen in this neighborhood, is still very light. Robins are scattered throughout the woods in loose flocks - a state of things not to be witnessed in summer or winter; the birds rising singly from the ground as the walker disturbs them, sometimes all silent, at other times all eackling noisily. Chickadees, too, are in flocks, cheerful companies, good to meet in any weather; behaving just as they will continue to do until the nesting season again breaks the happy assembly up into happier pairs.

My wood pewee - a particular bird in a grove near by - whistled pretty constantly till the 17th, and a warbling vireo was still true to his name on the 19th. I have heard no yellow-throated vireos since the 6 th, and conclude that they must have taken their 
departure. May joy go with them. This morning, for the first time in several weeks, a pine warbler was trilling. Song sparrows have grown numerous within a few days, but are almost entirely silent. One fellow sang his regular song - not his confused autumnal warble - on the 19th. I had not heard it before since the month opened.

No blackpoll warblers showed themselves with me till the 18th, though I had word of their presence elsewhere a few days earlier. On that day I saw three; yesterday and today have shown but one bird each. The movement is barely begun.

I should like to know how common it is for blackpolls to sing on their southward migration. Eleven years ago, in September, 1889, they came very early, - or I had the good fortune to see them very early, - and on the 4th and 5th of the month a few were " in full song," so my notes record, "quite as long and full as in May." I had never heard them sing before in autumn, nor have I ever had that pleasure since. Neither have I ever again seen them so early. Probably the two things - the song and the 
exceptional date - were somehow connected. At the time, I took the circunstance as an indication that the adult males migrate in advance of the great body of the species; and I fancied that, having detected them once thus early and thus musical, I should be likely to repeat the experience. If I am ever to do so, however, I must be about it. Eleven years is a large slice out of an adult man's remaining allowance.

On the 18th I found a single olive-backed thrush, silent, in company with a flock of robins, or in the same grove with them - a White Mountain bird, thrice welcome; and this morning a few white-throated sparrows appeared. The first one that I saw - the only one, in fact - was a young fellow, and as $I$ caught sight of him facing me, with his clear white throat, and his breast prettily streaked, with a wash of color across it, I was half in doubt what to call him. While I was taking observations upon his plumage, trying to make him look like himself, he began to chip, as if to help me out, and a second one unseen fell to singing near by; a very feeble and imperfect rendering of the 
dear old tune, but well marked by the "Peabody" triplets. It was a true touch of autumn, a voice from the hills.

Shortly before this I had spent a long time in watching the actions of a Lincoln finch. He was feeding upon Roman wormwood seeds by the roadside, in company with two or three chipping sparrows; very meek and quiet in his demeanor, and happily not disposed to resent my inquisitiveness, which I took pains to render as little offensive as possible. I had not seen the like of him since May, and have seen so few of his race at any time that every new one still makes for me an hour of agreeable excitement.

In the same neighborhood an indigo-bird surprised me with a song. He was as badly out of voice as the white-throat, but his spirit was good, and he sang several times over. One would never have expected music from him, to look at his plumage. The indigo color was largely moulted away - only the rags of it left. It was really pitiful to see him; so handsome a coat, now nothing but shreds and patches. Most likely he was not a traveler from farther north, but a lin- 
gering summer resident of our own, as I remember to have seen three birds of his name in the same spot fifteen days ago. It would be interesting to know whether bright creatures of this kind do not feel humiliated and generally unhappy when they find their beauty dropping away from them, like leaves from the branch, as the summer wanes.

The best bird of the month, so far, - better even than the Lincoln finch, _ was a Philadelphia vireo, happened upon all unexpectedly on the 17th. I had stopped, as I always do in passing, to look down into a certain dense thicket of shrubbery, through which a brook runs, a favorite resort for birds of many kinds. At first the place seemed to be empty, but in answer to some curiosity-provoking noises on my part a water thrush started up to balance himself on a branch directly under my nose, and the next moment a vireo hopped into full sight just beyond him; a vireo with plain back and wings, with no dark lines bordering the crown, and having the under parts of a bright yellow. He was most obliging; indeed, he could hardly have been more so, unless he 
had sung for me, and that was something not fairly to be expected. For a good while he kept silence. Then, in response to a jay's scream, he began snarling, or complaining, after the family manner. I enjoyed the sight of him as long as I could stay (he was the second one I had ever seen with anything like certainty), and when I returned, an hour later, he was still there, and still willing to be looked at.

And then, to heighten my pleasure, a rose-breasted grosbeak, invisible, but not far away, broke into a strain of most entrancing music; with no more than half his spring voice, to be sure, but with all his May sweetness of tone and inflection. Again and again he sang, as if he were too happy to stop. I had heard nothing of the kind for weeks, and shall probably hear nothing more for months. It was singing to be remembered, like Sembrich's "Casta Diva," or Nilsson's "I know that my Redeemer liveth."

Scarlet tanagers are still heard and seen occasionally, - one was calling to-day, - but none of them in tune, or wearing so much as 
a single scarlet feather. Here and there, too, as we wander about the woods, we meet - once in two or three days, perhaps - a lonesome-acting, silent red-eyed vireo. A great contrast there is between such solitary lingerers and the groups of gossiping chickadees that one falls in with in the same places; so merry-hearted, so bubbling over with high spirits, so ready to be neighborly. When I whistle to them, and they whistle back, I feel myself befriended.

Within a few days we must have the grand September influx of warblers - crowds of blackpolls, myrtles, black-throated greens, and many more. For two months yet the procession will be passing. 


\section{FOUR DREAMERS}

I REMEMBER the first man I ever saw sitting still by himself out of doors. What his name was I do not know. I never knew. He was a stranger, who came to visit in our village when I was perhaps ten years old. I had crossed a field, and gone over a low hill (not so low then as now), and there, in the shade of an apple tree, I beheld this stranger, not fishing, nor digging, nor eating an apple, nor picking berries, nor setting snares, but sitting still. It was almost like seeing a ghost. I doubt if I was ever the same boy afterward. Here was a new kind of man. I wondered if he was a poet! Even then I think I had heard that poets sometimes acted strangely, and saw things invisible to others' ken.

I should not have been surprised, I suppose, to have found a man looking at a picture, some " nice," high-colored "chromo," 
such as was a fashionable parlor ornament in our rural neighborhood, where there was more theology to the square foot (and no preacher then extant with orthodoxy strait enough to satisfy it, though some could still make the blood curdle) than there was of art or poetry to the square acre; but to be looking at Nat Shaw's hayfield and the old unpainted house beyond - that marked the stranger at once, as not belonging in the ranks of common men. If he was not a poet, he must be at least a scholar. Perhaps he was going to be a minister, for he seemed too young to be one already. A minister had to think, of course (so I thought then), else how could he preach? and perhaps this man was meditating a sermon. I fancied I should like to hear a sermon that had been studied out of doors.

Times have changed with me. Now I sit out of doors myself, and by myself, and look for half an hour together at a tree, or a bunch of trees, or a lazy brook, or a stretch of green meadow. And I know that such things can be enjoyed by one who is neither a poet nor a preacher, but just a quite ordinary, uneducated mortal, who happens, by 
the grace of God, to have had his eyes opened to natural beauty and his heart made sensitive to the delights of solitude. I have learned that it is possible to enjoy scenery at home as well as abroad, - scenery without mountains or waterfalls; scenery that no tourist would call "fine;" a bit of green valley, an ancient apple orchard, a woodland vista, an acre of marsh, a cattle pasture. In fact, I have observed that painters choose quiet subjects like these oftener than any of the more exceptional and stupendous manifestations of nature. Perhaps it is because such subjects are easier; but I suspect not. I suspect, indeed, that they are harder, and are preferred because, to the painter's eye, they are more permanently beautiful.

At this very moment I am looking at a patch of meadow inclosing a shallow pool of standing water, over the surface of which a high wind is chasing little waves. A few low alders are near it, and the grass is green all about. That of itself is a sight to make a man happy. For the world just now is consumed with drought. All the uplands are sere, and every roadside bush is begrimed 
with dust. I have come through the woods to this convenient knoll on purpose to find relief from the prevailing desolation — to rest my eyes upon green grass. For the eye loves green grass as well, almost, as the throat loves cold water.

Even in my boyish country neighborhood, though nobody, or nobody that I knew (which may have been a very different matter), did what I am now doing, there were some, I think (one or two, at least), who in their own way indulged much the same tastes that I have come to felicitate myself upon possessing. I remember one man, dead long since, who was continually walking the fields and woods, always with a spaniel at his heels, alone except for that company. $\mathrm{He}$ often carried a gun, and in autumn he snared partridges (how I envied him his skill!) ; but I believe, as I look back, that best and first of all he must have loved the woods and the silence. He was supposed to have his faults. No doubt he had. I have since discovered that most men are in the same category. I believe he used to "drink," as our word was then. But I think now that I should have 
liked to know him, and should have found him congenial, if I had been mature enough, and could have got below the protective crust which naturally grows over a man whose ways of life and thought are different from those of all the people about him. I have little question that when he was out of the sight of the world he was accustomed to sit as I do to-day, and look and look and dream.

One thing he did not dream of, - that a boy to whom he had never spoken would be thinking of him forty years after he had taken his last ramble and snared his last grouse.

"An idler," said his busier neighbors, though he earned his own living and paid his own scot.

"A misspent life," said the clergy, though he harmed no one.

But who can tell? "Who knoweth the interpretation of a thing?" Perhaps his, also, was - for him - a good philosophy. As one of the ancients said, "A man's mind is wont to tell him more than seven men that sit upon a tower." If we are not born alike, why should we be bound to live alike? "A 
handful with quietness" is not so bad a portion.

Yes, but time is precious. Time once past never returns.

True.

We must make the best of it, therefore.

True.

By making more shoes.

Nay, that is not so certain.

The sun is getting low. Longer and longer tree-shadows come creeping over the grass, making the light beyond them so much the brighter and lovelier. The oak leaves shimmer as the wind twists the branches. The green aftermath is of all exquisite shades. A beautiful bit of the world. The meadow is like a cup. For an hour I have been drinking life out of it.

Now I will return home by a narrow path, well-worn, but, barely wide enough for a man's steps; a path that nobody uses, so far as I know, except myself. Till within a year or two it belonged to a hermit, who kept it in the neatest possible condition. That was his chief employment. His path was the apple of his eye. He was as jealous 
over it as the most fastidious of village householders is over his front-yard lawn. Not a pebble, nor so much as an acorn, must disfigure it. Fallen twigs were his special abhorrence, though he treated them handsomely. Little piles or stacks of them were scattered at short intervals along the way, neatly corded up, every stick in line. I noticed these mysterious accumulations before I had ever seen the maker of them, and wondered not a little who could have been to so much seemingly aimless trouble. At first I imagined that some one must have laid the wood together with a view to carrying it home for the kitchen stove. But the bits were too small, no bigger round, many of them, than a man's little finger; not even Goody Blake could have thought such things worth pilfering for firewood; and besides, it was plain that many of them had lain where they were over at least one winter.

The affair remained a riddle until I saw the man himself. This I did but a few times, a long way apart, and always at a little distance. Generally his eyes were fastened on the ground. Sometimes he had a 
stick in his hand, and was brushing leaves and other litter out of the path. Perhaps he had married a model housekeeper in his youth, and had gone mad over the spring cleaning. He always saw me before I could get within easy speaking range ; and he had the true woodman's knack of making himself suddenly invisible. Sometimes I was almost ready to believe that he had dropped into the ground. Evidently he did not mean to be talked with. Perhaps he feared that I should ask impertinent questions. More likely he thought me crazy. If not, why should I be wandering alone about the woods to no purpose? I had no path to keep in order.

And perhaps I am a little crazy. Medical men insist upon it that the milder forms of insanity are much more nearly universal than is commonly supposed. Perfectly sound minds, I understand them to intimate, are quite as rare as perfectly sound bodies. At that rate there cannot be more than two or three truly sane men in this small town; and the probabilities are that $I$ am not one of them. 


\section{A DAY IN FRANCONIA}

IT is the most delightful of autumn days, too delightful, it seemed to me this morning, to have been designed for anything like work. Even a walking vacationer, on pedestrian pleasures bent, would accept the weather's suggestion, if he were wise. Long hours and short distances would be his programme; a sparing use of the legs, with a frequent resort to convenient fence-rails and other seasonable invitations. There are times, said I, when idleness itself should be taken on its softer side; and to-day is one of them.

Thus minded, I turned into the Landaff Valley shortly after breakfast, and at the old grist-mill crossed the river and took my favorite road along the hillside. As I passed the sugar grove I remembered that it was almost exactly four months since I had spent a delicious Sunday forenoon there, seated 


\section{A DAY IN FRANCONIA}

upon a prostrate maple trunk. Then it was spring, the trees in fresh leaf, the grass newly sprung, the world full of music. Bobolinks were rollicking in the meadow below, and swallows twittered overhead. Then I sat in the shade. Now there was neither bobolink nor swallow, and when I looked about for a seat I chose the sunny side of the wall.

Only four months, and the year was already old. But the mountains seemed not to know it. Washington, Jefferson, and Adams; Lafayette, Haystack, and Moosilauke ; - not a cloud was upon one of them. And between me and them lay the greenest of valleys.

So for the forenoon hours I sat and walked by turns; stopping beside a house to enjoy a flock of farm-loving birds, - bluebirds especially, with voices as sweet in autumn as in spring, - loitering under the long arch of willows, taking a turn in the valley woods, where a drumming grouse was almost the only musician, and thence by easy stages sauntering homeward for dinner.

For the afternoon I have chosen a road that might have been made on purpose for 
the man and the day. It is short (two miles, or a little more, will bring me to the end of it), it starts directly from the door, with no preliminary plodding through dusty village streets, and it is not a thoroughfare, so that I am sure to meet nobody, or next to nobody, the whole afternoon long. At any rate, no wagon loads of staring "excursionists" will disturb my meditations. It is substantially level, also; and once more (for a man cannot think of everything at once) it is wooded on one side and open to the afternoon sun on the other. For the present occasion, furthermore, it is perhaps a point in its favor that it does not distract me with mountain prospects. Mountains are not for all moods ; there are many other things worth looking at. Here, at this minute, as I come up a slope, I face halfway about to admire a stretch of Gale River, a hundred feet below, flowing straight toward me, the water of a steely blue, so far away that it appears to be motionless, and so little in volume that even the smaller boulders are no more than half covered. Beyond it the hillside woods are gorgeously arrayed - pale green, with reds 
and yellows of all degrees of brilliancy. The glory of autumn is nearly at the full, and at every step the panorama shifts. As for the day, it continues perfect, deliciously cool in the shade, deliciously warm in the sun, with the wind northwesterly and light. Many yellow butterflies are flitting about, and once a bright red angle-wing alights in the road and spreads itself carefully to the sun. While I am looking at it, sympathizing with its comfort, I notice also a shining dark blue beetle - an oil-beetle, I believe it is called - as handsome as a jewel, traveling slowly over the sand.

I have been up this way so frequently of late that the individual trees are beginning to seem like old friends. It would not take much to make me believe that the acquaintance is mutual. "Here he is again," I fancy them saying one to another as I round a turn. Some of them are true philosophers, or their looks belie them. Just now they are all silent. Even the poplars cannot talk, it appears (a most worthy example), without a breath of inspiration to set them going. The stillness is eloquent. A day like this is the 
crown of the year. It is worth a year's life to enjoy it. There is much to see, but best of all is the comfort that wraps us round and the peace that seems to brood over the world. If the first day was of this quality, we need not wonder that the maker of it took an artist's pride in his work and pronounced it good.

As for the road, there is still another thing to be said in its praise: While it follows a straight course, it is never straight itself for more than a few rods together. If you look ahead a little space you are sure to see it running out of sight round a corner, beckoning you after it. A man would be a poor stick who would not follow. Every rod brings a new picture. How splendid the maple leaves are, red and yellow, with the white boles of the birches, as white as milk, or, truer still, as white as chalk, to set off their brightness. I could walk to the world's end on such an invitation.

But the road, as I said, is a short one. Its errand is only to three farms, and I am now on the edge of the first of them. Here the wood moves farther away, and mountains come into view, _ Lafayette, Haystack, and 
the Twins, with the tips of Washington, Jefferson, and Adams. Then, when the second of the houses is passed, the prospect narrows again. An extremely pretty wood of tall, straight trees, many fine poplars among them (and now they are all talking), is close at my side. The sunlight favors me, falling squarely on the shapely, light-colored trunks (some of the poplars are almost as white as the birches), and filling the whole place with splendor. I go on, absorbed in the lovely spectacle, and behold, it is as if a veil were suddenly removed. The wood is gone, and the horizon is full of mountain-tops. I have come to the last of the farms, and in another minute or two am at the door.

There is nobody at home, to my regret, and I sit down upon the doorstep. Moosilauke, Kinsman, Cannon, Lafayette, Haystack, the Twins, Washington, Clay, Jefferson, Adams, and Madison - these are enough, though there are others, too, if a man were trying to make a story. All are clear of clouds, and, like the trees of the wood, have the western light full on them. Even without the help of a glass I see a train ascending Mt. Wash- 
ington. Happy passengers, say I. Would that I were one of them! The season is ending in glory at the summit, for this is almost or quite its last day, and there cannot have been many to match it, the whole summer through.

I loiter about the fields for an hour or more, looking at the blue mountains and the nearer, gayer-colored hills, but the occupant of the house is nowhere to be found. I was hoping for a chat with him. A seeing man, who lives by himself in such a place as this, is sure to have something to talk about. The last time I was here he told me a pretty story of a hummingbird. He was in the house, as I remember it, when he heard the familiar, squeaking notes of a hummer, and thinking that their persistency must be occasioned by some unusual trouble, went out to investigate. Sure enough, there hung the bird in a spider's web attached to a rosebush, while the owner of the web, a big yellow-and-brown, pot-bellied, bloodthirsty rascal, was turning its victim over and over, winding the web about it. Wings and legs were already fast, so that all the bird could do was to cry for 
help. And help had come. The man at once killed the spider, and then, little by little, for it was an operation of no small delicacy, unwound the mesh in which the bird was entangled. The lovely creature lay still in his open hand till it had recovered its breath, and then flew away. Who would not be glad to play the good Samaritan in such guise? As I intimated just now, you may talk with a hundred smartly dressed, smoothly spoken city men without hearing a piece of news half so important or interesting.

It is five o'clock when I leave the farms and am again skirting the woods. Now I face the sun, the level rays of which transfigure the road before me till its beauty is beyond all attempt at description. I look at it as for a very few times in my life I have looked at a painted landscape, with unspeakable enjoyment. The subject is of the simplest: a few rods of common grassy road, arched with bright leaves and drenched in sunshine; but the suggestion is infinite. After this the way brings me into sight of the fairest of level green meadows, with pools of smooth water - "water stilled at even" - 
90 THE CLERK OF THE WOODS and scattered farmhouses. The day is ending right; and when I reach the hotel piazza and look back, there in the east is the full moon rising in all her splendor, attended by rosy clouds. 


\section{WITH THE WADERS}

THE 12th of October was a day. There are few like it in our Massachusetts calendar. And by a stroke of good fortune I had chosen it for a trip to Eagle Hill, on the North Shore. All things were near perfection; the only drawbacks to my enjoyment being a slight excess of warmth and an unseasonable plague of mosquitoes.

"Yes, it is too fine," said the stable-keeper, who drove me down from the railroad station. "It won't last. It's what we call a weather breeder."

"So be it," thought I. Just then I was not concerned with to-morrow. Happy men seldom are. The stable-keeper spoke more to the purpose when he told me that during the recent storm a most exceptional number of birds had been driven in. A certain gunner, Cy Somebody, had shot twenty-odd dollars' worth in one day. "There he is now," 
he remarked after a while, as a man and a dog crossed the road just before us. " Any birds to-day, Cy?" he inquired. The man nodded a silent affirmative - a very unusual admission for a Yankee sportsman to make, according to my experience.

I was hardly on foot before I began to find traces of this good man's work. The first bird I saw was a sandpiper with one wing dragging on the ground. Near it was an unharmed companion which, even when I crowded it a little hard, showed no disposition to consult its own safety. "Well done," said I. " "There is a friend that sticketh closer than a brother." "

A few steps more, and a larger bird stirred amid the short marsh herbage beyond the muddy flat - a black-bellied plover, or " beetle-head." He also must be disabled, I thought, to be staying in such a place; and perhaps he was. At all events he would not fly, but edged about me in a half circle, with the wariest kind of motions (there was no sign of cover for him, the grass coming no more than to his knees), always with his big black eye fastened upon me, while my 
field-glass brought him near enough to show all the beauty of his spots.

He was well worth looking at ("What short work a gunner would make of him!" I kept repeating to myself), but I could not stay. Titlark voices were in the air. The birds must be plentiful on the grassy hills beyond ; with them there might be Lapland longspurs; and I followed the road. This presently brought me to a bit of pebbly beach, along which I was carelessly walking when a lisping sound caused me to glance down at my feet. There on the edge of the water was a bunch of seven sandpipers; white-rumps, as I soon made out, though my first thought had been of something else. One of them hobbled upon one leg, but the others seemed thus far to have escaped injury. There they stood, huddled together as if on purpose for some pot-shooter's convenience, while I drew them within arm's length ; pretty creatures, lovely in their foolish innocence; more or less nervous under my inspection, but holding their ground, each with its long black bill pointed against the breeze. "We who are about to die salute you," they might have been saying. 
Having admired them sufficiently, I passed on. Titlarks were beginning to abound, but where were the longspurs? A shot was fired some distance away, and as I looked in that direction two great blue herons went flying across the marsh, each with his legs behind him. It was good to see them still able to fly.

Then something - I have no idea what; no sight or sound that I was sensible of told me to look at a bird beside the little pool of water I had just passed. It was another white-rumped sandpiper, all by himself, nearer to me even than those I had left a little way back. What a beauty he was! - his dark eye (which I could see winking), the lovely cinnamon-brown shading of his back and wings, setting off the marbled black and white, and his shyly confiding demeanor. I had scarcely stopped before he flew to my side of the pool and stood as near me as he could get-too near to be shot at. He too had been hit, or so it seemed. One foot was painful, though he could put it down, if necessary, and even take a limping step upon it. Happy bird! He had fared well! 
Up the steep, grassy hill I started out of the road; but I soon halted again, this time to gaze into the sky. Straight above me were numbers of herring gulls, some far, far up under the fleecy cirrus clouds, others much lower. All were resting upon the air, sailing in broad circles. Round and round they went, - a kind of stationary motion, a spectator might have called it; but in a minute or two they had disappeared. They were progressing in circles, circle cutting circle. It is the sea-gull's way of taking a long flight. I remember it of old, and have never seen anything to surpass it for gracefulness. If there were only words to describe such things! But language is a clumsy tool.

The hilltop offered beauty of another kind: the blue ocean, the broad, brown marshes, dotted with haycocks innumerable, the hills landward, a distant town, with its spires showing, the inlet yonder, whitened with swimming gulls. Crickets chirped in the grass, herds of cattle and sheep grazed peacefully on all sides, and when I turned my head, there behind me, a mile away, 
perhaps, were the shining Ipswich dunes, wave on wave of dazzling white sand. I ought to have stayed with the picture, perhaps; but there were no longspurs, and somehow this was a day for birds rather than for a landscape. I would return to the muddy flats, and spend my time with the sandpipers and the plover. The telltale yellow-legs were whistling, and who could guess what I might see?

At the little pool I must stop for another visit with my single sandpiper. He would be there, I felt certain. And he was; as pretty as before, and no more alarmed at my presence, though as he balanced himself on one leg his body shook with a constant rhythmical pulsation, as if his heart were beating more violently than a bird's heart should. He did not look happy, I thought. And why should he, far from home, with a wounded foot, no company, and an unknown number of guns yet to face before reaching the end of his long journey? He was hardly bigger than a sparrow, but he was one of the creatures which lordly man, endowed with "godlike reason," a being of "large 
discourse," so wise and good that he naturally thinks of the Creator of all things as a person very like himself, finds it amusing to kill.

And when I came to the few rods of beach, there stood my seven sandpipers, exactly as before. They stirred uneasily under my gaze, whispering a few words to one another ("Will he shoot, do you think?"), but they kept their places, bunched closely together for safety. Did they know anything about their lonely brother - or sister - up yonder on the hillside? If they noticed her absence, they probably supposed her dead. Death is so common and so sudden, especially in migration time.

Now I am back again on a grassy mound by the muddy flats, and the big plover is still here. How alert he looks as he sees me approach! Yet now, as an hour ago, he shows no inclination to fly. The tide is coming in fast. $\mathrm{He}$ steps about in the deepening water with evident discomfort, and whether he will or not, he must soon take to wing or wade ashore. And while I am 
eyeing his motions my glass falls unexpectedly on two sandpipers near him in the grass; pectoral sandpipers - grass-birds I soon say to myself, with acute satisfaction. It is many years since I saw one. How small their heads look, - in contrast with the plover's, - and how thickly and finely their breasts are streaked! I remember the portrait in Nelson's " Birds of Alaska," with its inflated throat, a monstrous vocal sac, half as large as the bird itself. A graceful wooer!

They, too, are finding the tide a trouble, and no doubt are wishing the human intruder would take himself off. Now, in spite of my presence, one of them follows the other toward the land, scurrying from one bit of tussock to another, half wading, half swimming. Time and tide wait for no bird. Both they and the plover have given up all thoughts of eating. They have enough to do to keep their eyes upon me and the water.

The sandpipers, being smaller, make their retreat first. One, as he finds himself so near a stranger, is smitten with sudden 
fright, and runs by at full speed on his pretty dark-green legs. Yet both presently become reassured, and fall to feeding with all composure almost about my feet. I have been still so long that I must be harmless. And now the plover himself takes wing (I am glad to find he can), but only for a rod or two, alighting on a conical bit of island. There is nothing for him to eat there, apparently, but at least the place will keep his feet dry. He stands quiet, waiting. And so he continues to do for the hour and more that I still remain.

My own stay, I should mention, is by this time compulsory. I, too, am on an island (I have just discovered the fact), and not choosing to turn wader on my own account, must wait till the tide goes down. It is no hardship. Every five minutes brings me something new. I have only now noticed (a slight cry having drawn my attention) that there are sandpipers of another kind here - a little flock of dunlins, or redbacks. They are bunched on the pebbly edge of a second island (which was not an island a quarter of an hour ago), nearer to me even 


\section{THE CLERK OF THE WOODS}

than the plover's, and are making the best of the high tide, which has driven them from their feeding-grounds, by taking a siesta. Once, when I look that way, - which I can do only now and then, there are so many distractions, - I find the whole eight with their bills tucked under their wings. Now, is n't that a pretty sight! Their name, as I say, is the redbacked sandpiper; but at this season their upper parts are of a uniform mouse color, or soft, dark gray - I hardly know how to characterize it. It is very distinctive, whatever word we use, and equally so is the shape of the bill, long and stout, with a downward inflection at the tip. Eight birds, did I say? No, there are nine, for I have just discovered another, not on the island, but under the very edge of the grassy bank on which I am standing. $\mathrm{He}$ has a broken leg, poor fellow, and seems to prefer being by himself; but by and by, with a sudden cry of alarm, for which I can see no occasion, he flies to rejoin his mates.

Meanwhile, seven white-rumps have come and settled near them; the same flock that I saw yonder on the roadside beach, I have 
little question. Probably the encroaching tide has disturbed them also. At the same time I hear distant voices of yellow-legs, and presently six birds are seen flying in this direction. They wheel doubtfully at the unexpeeted sight of a man, and drop to the ground beyond range; but I can see them well enough. How tall they are, and how wide-awake they look, with their necks stretched out; and how silly they are, " telltales" and " tattlers" indeed, - to publish their movements and whereabouts to every gunner within a mile! While my head is turned they disappear, and I hear them whistling again across the marsh. They are all gone, I think; but as I look again toward my sandpipers' island, behold! there stands a tall fellow, his yellow legs shining, and his eye fastened upon me. Either he has lost his reason, if he ever had any, or he knows I have no gun. Perfectly still he keeps (he is not an absolute fool, I rejoice to see) as long as I am looking at him. Then I look elsewhere, and when my eye returns to his place, he is not there. He has only moved behind the corner 
of the islet, however, as I find when I shift my own position by a rod or two. He seems to be dazed, and for a wonder he holds his tongue.

Titlarks are about me in crowds. One is actually wading along the shore, with the water up to his belly. Yes, he is doing it again. I look twice to be sure of him. A flock of dusky ducks fly just above my head, showing me the lining of their wings. Truly this is a birdy spot; and luckily, though there are two or three "blinds" near, and guns are firing every few minutes up and down the marshes, there is no one here to disturb me and my friends. I could stay with them till night; but what is that? A buggy is coming down the road out of the hills with only one passenger. This is my opportunity. I pack up my glass, betake myself to the roadside, and when the man responds to my question politely, I take a seat beside him. As he gets out to unlatch the gate, a minute afterward, a light-colored dry-sand-colored - bird flies up and perches on a low fence-rail. This is no wader, but is none the less welcome. It is an Ipswich 
sparrow, I explain to my benefactor, who waits for me to take an observation. The species was discovered here, I tell him, and was named in the town's honor. He seems interested. "I should n't have known it," he says. So I have done some good to-day, though I have thought only of enjoying myself. 


\section{ON THE NORTH SHORE AGAIN}

If you have once seen a picture, says Emerson somewhere, never look at it again. $\mathrm{He}$ means that hours of insight are so rare that a really high and satisfying experience with a book, picture, landscape, or other object of beauty is to be accepted as final, a favor of Providence which we have no warrant to expect repeated. If you have seen a thing, therefore, really seen it and communed with the soul of it, let that suffice you. Attempts to live the hour over a second time will only result in failure, or, worse yet, will cast a shadow over what ought to have been a permanently luminous recollection.

There is a modicum of sound philosophy in the advice. We must take it as the counsel of an idealist, and follow it or not as occasion bids. The words of such men, as one of them was given to saying, are only for those who have ears to hear. We may be 
ON THE NORTH SHORE AGAIN 105

sure of one thing: poems, landscapes, pictures, and all other works of art (art human or superhuman) are never to be exhausted by one look, or by a hundred. If a man is good for anything, and the poem or the landscape is good for anything, he will find new meanings with new perusals. In other words, we may turn upon Emerson and say: "Yes, but then, you know, we never do see a picture - a picture that is a picture."

As was related a week ago, I spent the 12th of October on the North Shore. I brought back the remembrance of a glorious piece of the world's beauty. In outline, I had it in my mind. But I knew perfectly, both at the time and afterward, that I had not really made it my own. I had been too much taken up with other things. The eye does not see the landscape; nor does the mind see it. The eye is the lens, the mind is the plate. The landscape prints itself upon the mind, through the eye. But the mind must be sensitive and still, and - what is oftener forgotten - the exposure must be sufficiently prolonged. The clearest-eyed genius ever born never saw a landscape in ten minutes. 
On all grounds, then, I was entitled to another look. And this time, perhaps, the Lapland longspurs would be there to be enjoyed with the rest. I would go again, therefore; and on the morning of the 18th, long before daylight, judging by the quietness of the trees outside that the wind had gone down (for wind is a serious hindrance to quiet pleasure at the seashore in autumn, and visits must be timed accordingly), I determined to set out in good season and secure a longish day. Venus and the old moon were growing pale in the east when I started forth, and three hours afterward I was footing it through Ipswich village toward East Street and the sea.

As I crossed the marsh and approached the gate, a stranger overtook me. We managed the business together, one pulling the gate to, the other tending the hook and staple, and we spoke of the unusual greenness of the hills before us, on which flocks and herds were grazing. "There 's better feed now than there's been all summer," the stranger said. It was easy to believe it. Those broad-backed, grassy hills are one of the glories of the North Shore. 
I followed the road as it led me among them. A savanna sparrow had been dodging along the edge of a ditch near the gate; titlark voices at once became common, and after a turn or two I saw before me a bunch of shore larks dusting themselves in the sandy middle of the track. They were making thorough work of it, crowding their breasts and necks, and even the sides of their heads into the soil, with much shaking of feathers afterward.

The road brought me to a beach, where were two or three houses, and, across the way, a pond stocked with wooden geese and ducks, with an underground blind for gunners in the side of the hill. Some delights are so keen that it is worth elaborate preparations to enjoy them. Here the titlarks were in extraordinary force, and I lingered about the spot for half an hour, awaiting the longspurs that might be hoped for in their company. Hoped for, but nothing more. I was still too early, perhaps.

Well, their absence, the fact of it once accepted, left me free-minded for the main object of my trip. I would go up the hill, 
over the grass, and take the prospect northward. A narrow depression, down which 'a brook trickled with a pleasant, companionable noise, as if it were talking to itself, afforded me shelter from the wind, and at the same time bounded my outlook on either side, as a frame bounds a picture. The hill fell away sharply to the water just beyond my feet, and up and down the inlet gulls were flying. Once, to my pleasure, two black-backed "coffin-bearers" passed, the only ones I was able to discover among the thousands of herring gulls that filled the air and the water, and crowded the sand-bars, the whole day long. Across the blue water were miles of brown marsh, and beyond the marsh rose wooded hills veiled with haze, the bright autumnal colors shining through. Crickets were still musical, buttercups and dandelions starred the turf, and once a yellow butterfly (Philodice) flitted near. The summer was gone, but here were some of its children to keep it remembered. Titlarks walked daintily about the grass, or balanced themselves upon the boulders, and once I turned my head just in time to see a marsh 
hawk sailing over the hill at my back, his white rump showing.

When I had left the hills behind me, and was again skirting the muddy flats, I found myself all at once near a few sandpipers, a dozen, more or less, of white-rumps, one with a foot dragging, one with a leg held up, and beside them a single red-back, or dunlin, staggering on one leg, the same bird, it seemed likely, that I had pitied a week ago. I pitied him still. Ornithology, studied under such conditions, was no longer the cheerful, exhilarating science to which I am accustomed. It was more like sociology.

Perhaps I am sentimental. If so, may I be forgiven. There is no man but has his weakness. The dunlin was nothing, I knew; one among thousands; a few ounces of flesh with feathers on it; what if he did suffer? It was none of my business. Why should I take other men's amusements sadly? The bird was greatly inferior to the being who shot him ; at least that is the commonly accepted theory ; and the superior, as every one but an anarchist must admit, has the rights 
of superiority. And for all that, the dunlin seemed a pretty innocent, and I wished that he had two good legs. As for his being only one of thousands, so am I - and no very fine one either; but I should n't like to be shot at from behind a wall; and when I have a toothache, the sense of my personal insignificance is of small use in dulling the pain. Poor dunlin!

I allowed myself two hours from the gate back to the railroad station, though it is less than an hour's walk. Some of the fairest views are to be obtained from the road; and there, I told myself, I should be sheltered from the wind and could sit still at my ease. The first half of the distance, too, would take me between pleasant hedgerows, in which are many things worthy of a stroller's notice.

For some time, indeed, I did little but stop and look behind. The marshes pulled me about: so level, so expansive, so richly brown, so pointed with haycocks (once, the notion taking me, I counted far enough to see that there were more than two hundred in sight), and so beautifully backed by the 
golden autumnal hills. I can see them yet, though I have nothing to say about them.

"The world lies east : how ample, the marsh and the sea and the sky!"

Trains of gulls went flying up the inlet as the tide went out. They live by the sea's almanac as truly as the clam-diggers, two of whom I had watched, an hour before, sailing across the inlet in a rude boat (more picturesque by half than a gentleman's yacht), and setting about their day's work on a shoal newly uncovered. Thank Heaven, there are still some occupations that cannot be carried on in a factory.

The roadsides were bright with gaycolored fruits : barberries, thorn apples, Roxbury waxwork, and rose-hips. Of thorn bushes there were at least two kinds; one already bare-branched, with scattered small fruit; the other still in leaf, and loaded with gorgeous clusters of large red apples. More interesting to me than any of these were the frost grapes; familiar acquaintances of an Old Colony boyhood, but now grown to be strangers. They were shining black, ripe 
and juicy (of the size of peas), and if their sweetness failed to tempt the palate, that, for aught I know, may have been the eater's fault rather than theirs. Why might not their quality be of a too excellent sort, beyond his too effeminate powers of appreciation? Is there any certainty that man's taste is final in such matters? Was my own criticism of them anything more than a piece of unscientific, inconclusive impressionism?

Surely they were not without a tang. The most exacting mouth could not deny them individuality. I tried them, and retried them; but after all, they seemed most in place on the vines. To me, in the old days, they were known only as frost grapes. Others, it appears, have called them chicken grapes, possum grapes, and winter grapes. No doubt they find customers before the season is over. Thorean should have liked them and praised them, but I do not recall them in his books. Probably they do not grow in Concord. They are of his kin, at all events, wildings of the wild. I wish I had brought a bunch or two home with me. In my present mood I believe they would "go to the spot." 
But if I was glad to see the frost grapes, I was gladder still to see a certain hickory tree. I was scarcely off the marsh before I came to it, and had hardly put my eye upon it before I said to myself (although so far as I could have specified, it looked like any other hickory; but there is a kind of knowledge, or half knowledge, that does not rest upon specifications), "There! That should be a bitternut tree." Now the bitternut is not to be called a rarity, I am assured; but somehow I had never found it, notwithstanding I was a nut-gatherer in my youth, and have continued to be one to this day, an early taste for wild forage being one of the virtues that are seldom outgrown. Well, something distracted my attention just then, and I contented myself with putting a leaf and a handful of nuts into my pocket. Only on getting home did I crack one and find it bitter. Now, several days afterward, I have cracked another, and tested it more fully. The shell is extremely thin, - like a pecan nut's for fragility, - and the meat, which is large and full, is both bitter and puckery, suggesting the brown inner partitions of a 
pecan shell, which the eater learns so carefully to avoid. In outward appearance the nut is a pig-nut pure and simple, the reader being supposed to be enough of a countryman to know that pig-nuts, like wild fruits in general, vary interminably in size, shape, and goodness.

Pretty butter-and-eggs still bloomed beside the stone wall, and the "folksy mayweed" was plentiful about a barnyard. Out from the midst of it scampered a rabbit as I approached the fence to look over. He disappeared in the cornfield, his white tailtip showing last, and I wondered where he belonged, as there seemed to be neither wood nor shrubbery within convenient distance.

Just beyond this point (after noticing a downy woodpecker in a Balm-o'-Gilead tree, if the careful compositor will allow me that euphonious Old Colony contraction), I had stopped to pick up a shagbark when five children, the oldest a girl of nine or ten, came down the road together.

"Out of school, so early?" said I.

"No," was the instantaneous response; "we 've got the whooping cough." 
" Ah, that's better than going to school, is n't it?" said I, not so careful of my moral influence as a descendant of the Puritans ought to have been, perhaps; but I spoke from impulse, remembering myself how I also was tempted.

"Yes," said one of the children; "No," said another; and the reader may believe which he will, looking into his own childish heart, if he can still find it, as I hope he can.

Apple trees were loaded; hollyhocks, marigolds, and even tender cannas and dahlias, still brightened the gardens (so much for being near the sea, even on the North Shore), but what I most admired were the handsome yellow quinces in many of the door-yards. Quince preserve must be a favorite dish in Ipswich. I thought I should like to live here. I could smell the golden fruit - in my' mind's nose - clean across the way. And when I reached the village square I stopped (no, I walked slowly) to watch a real Old Colony game that I had not seen played for many a day. Two young men had stuck a jackknife into the hard earthen 


\section{THE CLERK OF THE WOODS}

sidewalk and were "pitching cents." It was like an old daguerreotype. One of the gamesters was having hard luck, but was taking it merrily. "I owe you six," I heard him say, as his coin stood on edge and rolled perversely away from the knife-blade.

This was very near to "Meeting-house Green." I hope I am doing no harm to speak of it. 


\section{AUTUMNAL MORALITIES}

For the month past my weekly talk has been more or less a traveler's tale - of things among the mountains and at the seaside. Now, on this bright afternoon in the last week of October, a month that every outdoor man saddens to see coming to an end (like May, it is never half long enough), let me note a little of what is passing in the lanes and byroads nearer home.

Leaves are rustling below and above. As is true sometimes in higher circles, they seem to grow loquacious with age; the slightest occasion, the merest nudge of suggestion, the faintest puff of the spirit sets them off. For me they will never talk too much. I love their preaching seven days in the week. The driest of them never teased my ears with a dry sermon. I scuff along the path on purpose to stir them up. " Your turn will come next," I hear them saying; but the message 
does not sound like bad news. I listen to it with a kind of pleasure, as to solemn music. If the doctor or the clergyman had brought me the same word, my spirit might have risen in rebellion; but the falling leaf may say what it likes. It has poet's leave.

How gracefully they come to the ground, here one and there another; slowly, slowly, with leisurely dips and turns, as if the breeze loved them and would buoy them up till the last inevitable moment. Children of air and sunshine, they must return to the dust. So all things move in circles, - life and death, death and life. Happy leaves! they depart without formalities, with no funereal trappings. The wind whispers to them, and they follow.

As I watch them falling, a gray squirrel startles me. I rejoice to see him. He, too, is a falling leaf. In truth, his living presence takes me by surprise. So many gunners have been in this wood of late, all so murderously equipped, that I had thought every squirrel must before this time have gone into the game-bag. Be careful, young fellow; you will need all your spryness and 
cunning, all your knack of keeping on the invisible side of the trunk, or your frolic will end in sudden blackness. This is autumn, the sickly season for squirrels and birds. "The law is off," and the gun is loaded to kill you. Take a friend's advice, and fight shy of everything that walks upright " in the image of God."

Yonder round-topped sweet-birch tree is one of October's masterpieces; a sheaf of yellow leaves with the sun on them. How they shine! Yet it is not so much they as the sunlight. Nay, it is both. Let the leaves have the honor that belongs to them. In a week they will all be under foot. Today they are bright as the sun, and airy and frolicsome as so many butterflies. Blessed are my eyes that see them. And look! how the light (what a painter it is!) glorifies the lower trunk of the white oak just beyond. The furrowed gray bark is so perfect a piece of absolute beauty that, if it were framed and set up in a gallery, the crowd - or the few that are better than a crowd - would be always before it. So cheap and universal are visual delights, so little dependent upon 
place or season - sunlight and the bark of a tree!

In the branches overhead are chestnutloving blackbirds, every one with a crack in his voice. Far away a crow is cawing, and from another direction a jay screams. These speak to the world at large. Half the township may hear what they have to offer. I like them; may their speech never be a whit softer or more musical; but if comparisons are in order, I give my first vote for less public - more intimate - birds, such as speak only to the grove or the copse. And even as I confess my preference, a bluebird's note confirms it: a voice that caresses the ear ; such a tone as no human mouth or humanly invented instrument can ever produce the like of. He has no need to sing. His simplest talk is music.

Here, by the wayside, a few asters have sprung up after the scythe, and are freshly in flower. How blue they are! And how much handsomer a few stalks of them look now than a full acre did two months ago. So acceptable is scarcity. There is nothing to equal it for the heightening of values. It is 
only the poor who know what money is worth. It is only in October and November that we feel all the charm of Aster loevis. I think of Bridget Elia's lament over the "good old times" when she and her cousin were "not quite so rich." Then the spending of a few shillings had a zest about it. A purchase was an event, a kind of festival. I believe in Bridget's philosophy; for the asters teach the same; yes, and the goldenrods also. They, too, have come up in the wake of the scythe, and still dwarfed, having no time to attain their natural growth, as if they knew that winter was upon them, are already topped with yellow. I carry home a scanty half handful of the two, asters and goldenrods, as treasure-trove. They are sure to be welcome. When all the fields were bright with such things, they seemed hardly worth house-room. This late harvest of blossoms is one small compensation for all the ugliness inflicted upon the landscape by the habit inveterate with highway " commissioners" of mowing back-country roadsides. As if stubble were prettier than a hedge!

Now I pass two long-armed white oaks, 
which I never come near without thinking of a friend of mine and of theirs who used to walk hereabouts with me; a real tree lover, who loves not species, not white oaks and red oaks, but individual trees, and goes to see them as one goes to see a man or a woman. This pair he always called the twins. They have summered and wintered each other for a hundred years. Who knows - putting the matter on grounds of pure science - whether they do not enjoy each other's companionship? Who knows that trees have no kind of sentience? Not I. We take a world of things for granted; and if all our neighbors chance to do the same, we let the general assumption pass for certainty. If trees do know anything, I would wager that it is something worth knowing, something quite as good as is to be found in any newspaper.

Here are red maples as bare as December, and yonder is one that is almost in full leaf; and by some freak of originality every leaf is bright yellow. Three days more and it will be naked also. Under it are white-alder bushes (Clethra) clothed in dark purple, and 
tall blueberry bushes all in red, with yellow shadings by way of contrast. This is in a swampy spot, where a lonesome hyla is peeping. Just beyond, the drier ground is reddened - under the trees - with huckleberry and dangleberry. Nobody who has not attended to the matter would imagine how much of the brightness of our New England autumn - one of the pageants of the world - is due to these lowly bushes, which most people think of solely as useful in the production of pies and puddings. Without being mown, the huckleberry bears a second crop - a crop of color. It is twice blest; it blesses him that eats and him that looks. In many parts of New England, at least, the autumnal landscape could better spare the maples than the blueberries and the huckleberries. Rum-cherry trees and shrubs more shrubs than trees - are dressed in lovely shades of yellow and salmon. Spicebushes wear plain yellow of a peculiarly delicate cast. I roll a leaf in my hand and find it still spicy. A bush looks handsomer, I believe, if it is known to smell good. The same thought came to me a week ago while I was 
124 THE CLERK OF THE WOODS

admiring the sassafras leaves. They were then just at the point of ripeness. Now they have turned to a dead brown. The maple's way is in better taste - to shed its leaves while they are still bright and fresh. They are under my feet now, a carpet of red and yellow.

One of the oddest bits of fall coloration (I cannot profess greatly to like it) is the ghostly white-greenish white - of Roxbury waxwork leaves. It is unique in these parts, so far as I can recall, but is almost identical with the pallor of striped maple foliage (Acer Pennsylvanicum) as one sees it in the White Mountains. Waxwork pigments all go to the berries, it appears. These are showy enough to suit the most barbaric taste, and are among the things that speali to me strongest of far-away times, when my childish feet were just beginning to wander in nature's garden. The sight of them reminds me of what a long time I have lived.

A gust of wind strikes a tall willow just as I approach it. See the leaves tumble! Thick and fast they come, a leafy shower, with none of those pretty, hesitating, para- 
chute-like reluctances which we noticed the rounder and lighter birch leaves practicing half an hour ago. The willow leaves, narrow and pointed, fall more like arrows. I am put in mind, I cannot tell why, of an early morning hour, years ago, when I happened to cross a city garden after the first killing frost, and stopped near a Kentucky coffee tree. Its foliage had been struck with death. Not a breath was stirring, but the leaves, already blackened and curled, dropped in one continuous rain. The tree was out of its latitude, and had been caught with its year's work half done. The frost was a tragedy. This breeze among the willow branches is nothing so bad as that. Its errand is all in the order of nature. It calls those who are ready.

My meditations are still running with the season, still playing with mortality, when a blue jay quits a branch near by ( $I$ had not seen him) and flies off in silence. The jay is a knowing bird. No need to tell him that there is a time for everything under the sun. He has proverbial philosophy to spare. Hark! he has found his voice; like a saucy schoolboy, who waits till he is at a safe distance and 


\section{THE CLERK OF THE WOODS}

then puts his thumb to his nose, and cries "Yaah, yaah!"

Well, the reader may thank him for one thing. He has made an end of my autumnal sermon, the text of which, if any one cares to look for it, may be found in the sixty-fourth chapter of Isaiah, at the sixth verse. 


\section{A TEXT FROM THOREAU}

"There is no more tempting novelty than this new November. No going to Europe or to another world is to be named with it. Give me the old familiar walk, post-office and all, with this ever new self, with this infinite expectation and faith which does not know when it is beaten. We 'll go nutting once more. We'll pluck the nut of the world and crack it in the winter evenings. Theatres and all other sight-seeing are puppet shows in comparison. I will take another walk to the cliff, another row on the river, another skate on the meadow, be out in the first snow, and associate with the winter birds. Here I am at home. In the bare and bleached crust of the earth, I recognize my friend."

Thus bravely did Thoreau enter upon the gray month. It was in 1858 , when he was forty-one years old. He wants nothing new, 
he assures himself. He will "take the shortest way round and stay at home." "Think of the consummate folly of attempting to go away from here," he says, underscoring the final word. As if whatever place a man might move to would not be "here" to him! As if he could run away from his own shadow! So I interpret the italies.

His protestations, characteristically unqualified and emphatic, imply that thoughts of travel have beset him. Probably they beset every outdoor philosopher at this shortday season. They are part of the autumnal crop. Our northern world begins to look in cloudy moods - like a place to escape from. The birds have gone, the leaves have fallen, the year is done. "Let us arise and go also," an inward voice seems to whisper. Not unlikely there is in us all the dormant remainder of an outworn migratory instinet. Civilization has caged us and tamed us; "hungry generations" have trodden us down; but below consciousness and memory there still persists the blind stirring of ancestral impulse. The fathers were nomads, 
and the children's feet are still not quite content with day's work in a treadmill.

Let our preferences be what they may, however, the greater number of us must stay where we are put, and play the hand that is dealt to us, happy if we can face the dark side of the year with a measure of philosophy. If there is a new self, as Thoreau says, there will be a new world and a new season. If we carry the tropics within us, we need not dream of Florida. And even if there is no constraint upon our going and coming, we need not be in haste to run away. We may safely wait a week or two, at least. November is often not half so bad as it is painted - not half so bad, indeed, as Thoreau himself sometimes painted it. For the eleventh month was not one of his favorites. "November Eat-Heart," he is more than once moved to call it. The experience of it puts his equanimity to the proof. Even his bravest words about it sound rather like a defiance than a welcome, - a little as if he were whistling to keep up his courage. With the month at its worst, he confesses, he has almost to drive himself 
afield. He can hardly decide upon any route; "all seem so unpromising, mere surface-walking and fronting the cold wind." "Surface-walking." How excellent that is ! Every contemplative outdoor man knows what is meant, but only Thoreau could have hit it off to such perfection in a word.

I must admit that I am not sorry to find the Walden stoic once in a long while overtaken by such a comparatively unheroic mood. $\mathrm{He}$ boasted so often and so well (with all the rest he boasted of his boasting) that it pleases me to hear him complain. So the weather could be too much even for him, I say to myself, with something like a chuckle. He was mortal, after all ; and the day was sometimes dark, even in Concord.

Not that he ever whimpered. And had he done so, in any moment of weakness, it should never have been for me to lay a public finger upon the fact. Nobody shall be more loyal to Thoreau than I am, though others may understand him better and praise him more adequately. If he complained, he did it "man-fashion," and was within a man's right. To say that the worst of Massachu- 
setts weather is never to be spoken against is to say too much; it is stretching the doctrine of non-resistance to the point of absurdity. As well forbid us to carry umbrellas, or to put up lightning-rods. There is plenty of weather that deserves to be spoken against.

Only let it be done, as I say, "manfashion;" and having said our say, let us go about our business again, making the best of things as they are - as Thoreau did. For, having owned his disrelish for what the gods provided, he quickly recovered himself, and proceeded to finish his entry in a cheerier strain. Matters are not so desperate with him, after all. He has to force himself out of doors, it is true, but once in the woods he often finds himself " unexpectedly compensated." "The thinnest yellow light of November is more warming and exhilarating than any wine they tell of." He meets with something that interests him, and immediately the day is as warm as July - as if the wind had shifted from northwest to south. There is the secret, in November as in May - to be interested. Then there is no longer 
a question of "surface walking." The soul is concerned, and life has begun anew.

Thus far, the present November (I write on the 4th) has been unusually mild; some days have been really summer-like, too warm for comfort; but the sun has shone only by minutes-now and then an hour, at the most. Deciduous trees are nearly bare, the oaks excepted; flowers are few and mostly out of condition, though it would be easy to make a pretty high-sounding list of names ; and birds are getting to be almost as scarce as in winter. There is no longer any quiet strolling in the woods. If you wish to listen for small sounds you must stand still. The ground is so thick with crackling leaves that it is impossible to go silently. Everything prophesies of the death of the year. It is almost time for the snow to fall and bury what remains of it.

Yet in warm days one may still see dragon-flies on the wing. Yesterday meadow larks were singing with the greatest abandon and in something like a chorus. I must have seen a dozen, and most if not all of them were in tune. On the 1st of 
the month a grouse drummed again and again; an unseasonable piece of lyrical enthusiasm, one might think; but I doubt if it was anything so very exceptional. Once, indeed, a few years ago, I heard a grouse drum repeatedly in January, on a cloudy day, when the ground in the woods was deep under snow. That, I believe, was an event much out of the common, though by no means without precedent. I wish Thoreau could have been there; he would have improved the occasion so admirably. So long as the partridge can keep his spirits up to the drumming point, why should the rest of us outdoor people pull a long face over hard times and short rations? Shall we be less manly than a bird?

The partridge will neither migrate nor hibernate, but looks winter in the eye and bids the wind whistle. It is too bad if we who command the services of coal dealers and plumbers, tailors and butchers, doctors and clergymen, cannot stand our ground with a creature that knows neither house nor fuel, and has nothing for it, summer and winter, but to live by his wits. To the partridge 


\section{THE CLERK OF THE WOODS}

man must look like a weak brother, a coddler of himself, ruined by civilization and "modern improvements;" a lubber who would freeze to death where a chickadee bubbles over with the very joy of living.

With weather-braving souls like these Thorean would associate; and so will I. It is true, what all the moralists have told us, that it is good for a man to keep company with his superiors. Not that in my own case I look for their example and tuition to make me inherently better; it is getting late for that; "nothing that happens after we are twelve counts for very much;" I shall be content if they make me happier. And so much I surely depend upon. Good spirits are contagious. It is the great advantage of keeping a dog, that he has happiness to spare, and gives to his master. So a flock of chickadees, or snowbirds, or kinglets, or tree sparrows, or goldfinches brighten a man's day. He comes away smiling. I will go out now and prove it. 


\section{THE PLEASURES OF MELAN- CHOLY}

THis wintry November forenoon I was on a sea beach; the sky clouded, the wind high and cold, cutting to the marrow; a bleak and comfortless place. A boy, dragging a child's cart, was gathering chips of driftwood along the upper edge of the sand, - one human figure, such as painters use to make a lonesome scene more lonesome. A loon, well offshore, sat rocking upon the water, now lifted into sight for an instant, now lost behind a wave. Distant sails and a steamship were barely visible through the fog. So much for the world on its seaward side. There was little to cheer a man's soul in that quarter.

On the landward side were thickets of leafless rosebushes covered with scarlet hips; groves of tall, tree-like, smooth-barked alders; swampy tracts, wherein were ilex 
bushes bright with red Christmas berries, and blueberry bushes scarcely less bright with red leaves. Sometimes it was necessary to put up an opera-glass before I could tell one from the other. Here was a marshy spot; dry, shivering sedges standing above the ice, and among them four or five mudbuilt domes of muskrat houses. Shrewd muskrats! They knew better than to be stirring abroad on a day like this. "If you have n't a house, why don't you build one?" they might have said to the man hurrying past, with his neck drawn down into his coat collar. Here I skirted a purple cranberry bog, having tufts of dwarfed, stubby bayberry bushes scattered over it, each with its winter crop of pale-blue, densely packed, tightly held berry clusters.

Not a flower; not a bird. Not so much as a crow or a robin in one of the stunted savin trees. I remembered winter days here, a dozen years ago, when the alder clumps were lively with tree sparrows, myrtle warblers, and goldfinches. Now the whole peninsula was a place forsaken. I had better have stayed away myself. Here, as so often elsewhere, memory was the better sight. 


\section{THE PLEASURES OF MELANCHOLY 137}

By a summer cottage upon the rocks was a ledge matted over with the Japanese trailing white rose. There were no blossoms, of course, but what with the leaves, still of a glossy green, and the bunches of handsome, high-colored hips, the vine could hardly have been more beautiful, I was ready to say, even when the roses were thickest upon it. Beside another house a pink poppy still looked fresh. Frail, belated child of summer! I could hardly believe my eyes. All its human admirers were gone long since. Every cottage stood vacant. Nobody would live here in this icy wind, if he could find another place to flee to. I remembered Florida beaches, summery abodes, where every breath from the sea brought a welcome coolness. Why should I not take the next train southward? Shall a man be less sensible than a bird?

That was five or six hours ago. Now I am a dozen miles inland. The air is so still that the sifting snowflakes fall straight downward. Even the finest twigs of the gray birches, so sensitive to the faintest breath, can hardly be seen to stir. A narrow foot- 
path under the window is a line of white running through the green grass. Beyond that is the brown hillside, brightened with a few pitch-pines; and then a veil shuts down upon the world, with a spray of bare treetops breaking through. It is the gray month in its grayest mood.

Be it so. I will sit at my window and enjoy the world as it is. This sombre day has a beauty and charm of .its own - the charm of melancholy. The wise course is to tune our thought to nature's mood of soberness, rather than to force a different note, profaning the hour, and cheating ourselves with shallow talk and laughter. There is a time for everything under the sun - L' Allegro and Il Penseroso, each in its turn.

Now is a time to think of what has been and of what will be. Only the other day the year was young; grass was greening, violets were budding, birds were mating and singing. Now the birds are gone, the flowers are dead, the year is ending as all the years have ended before it.

And as the year is, so are we. A few days ago we were children, just venturing to 


\section{THE PLEASURES OF MELANCHOLY 139}

run alone. We knew nothing, had seen nothing, looked forward to nothing. Life for us was only a day in a house and a dooryard, a span of playtime between two sleeps.

A few days ago, I say. Yet what a weary distance we have traveled since then, and what an infinity of things we have seen and dealt with. How many thoughts we have had, coming we know not whence, how many hopes, one making way for the other, how many dreams. We have made friends; friends that were to be friends forever; and long, long ago, with no fault on either side, the currents of the world carrying us, they and we have drifted apart. It is all we can do now to recall their names and their manner of being. Some of them we should pass for strangers if we met them face to face.

What a long procession of things and events have gone by us and been forgotten. Almost we have forgotten our own childish names, it is so many years since any one called us by them. Should we know ourselves, even, if we met in the street the boy or girl of thirty or forty or fifty years ago? Was it indeed we who lived then? who believed 
such things, enjoyed such things, concerned ourselves with such things, trembled with such fears, were lifted up by such hopes, felt ourselves enriched by such havings? How shadowy and unreal they look now; and once they were as substantial as life and death. Nay, it is some one else whose past we are remembering. The boy and the man cannot be the same.

Shall we rejoice or be sad that we have outgrown ourselves thus completely? Something of both, perhaps. It matters not. The year is ending, the night is falling. The past is as if it had never been; the future is nothing; and the present is less than either of them. Life is a vapor; nothing, and less than nothing, and vanity.

So we say to ourselves, not sadly, but with a kind of satisfaction to have it so. Yet we love to live over the past, and, with less assurance, to dream of the future.

"The flower that once has blown forever dies."

Yes, we have heard that, and we will not dispute ; this is not an hour for disputing ; but the flowers that bloomed forty years 
ago - the iris and the four-o'clocks in a child's garden - we can still see in recollection's magic glass. And they are brighter than any rose that opened this morning. We have forgotten things without number; but other things - we shall never forget them. A friend or two that died when they and we were young; "the loveliest and the best;" we can see them more plainly than most of those whose empty, conventionalized faces, each like the other, each wearing its mask, we meet day by day in the common round of business and pleasure. Death, which seemed to destroy them, has but set them beyond the risk of alteration and forgetfulness.

After all, the past is our one sure possession. There is our miser's chest. With that, while memory holds for us the key, we shall still be rich. There we will spend our gray hours, with friends that have kept their youth; one of the best of them our own true self, not as we were, nor as we are, but as we meant to be.

"These pleasures, Melancholy, give; And I with thee will choose to live." 


\section{IN THE OLD PATHS}

For men who know how to bear themselves company there are few better ways of improving a holiday, especially a home-keeping, home-coming, family feast, like our autumnal Thanksgiving, than to walk in one's own childish steps - up through the old cattle pasture behind the old homestead, into the old woods. Every jutting stone in the path - and there are many - is just where it was. Your feet remember them perfectly (as your hand remembers which way the door-knob turns, though you yourself might be puzzled to tell), and of their own accord take a zigzag course among them, coming down without fail in the clear intermediary spaces. Or if, by chance, in some peculiarly awkward spot, the toe of your boot forgets itself, the jar only helps you to feel the more at home. You say with the poet, "I have been here before." Some things are unaltered, 
you are glad to find. The largest of the trees have been felled, but nobody has dug out the protruding boulders or blasted away the outcropping ledges. One good word we may say for death. It lasts well. It is nothing like a vapor.

Not a rod of the way but talks to you of something. Here, on the left, down in the hollow by the swamp, you used to set snares. Once - fateful day! - you found a partridge in the noose. Then what a fury possessed you! If you had shot your first elephant you could hardly have been more completely beside yourself. It was a cruel sight; you felt it so; but you had caught a partridge! With all your boyish unskillfulness you had lured the unhappy bird to his death. A spray of red barberries had been too bright for his resistance. He discovered his mistake when the cord began to pull. "Oh, why was I such a fool!" he thought; just as you have thought more than once since then, when you have run your own neck into some snare of the fowler.

Yonder, on the right, grew little scattered patches of trailing arbutus. Every spring 


\section{THE CLERK OF THE WOODS}

you gathered a few blossoms, going thither day after day, watching for them to open. And the patches are there still. Some of them are no broader than a dinner plate, and the largest of them would not cover the top of a bushel basket. For more than fifty years - perhaps for more than five hundred - they have looked as they do now; a few score of leaves and an annual crop of a dozen or two of flowers. Their endurance, with so many greedy hands after them, is one of the miracles. Probably they are older than any tree in the township. It is n't the tall things that live longest.

Here the path goes through an opening in a rude stone wall, which was tumbling down as long ago as you can remember. Beyond it, in your day, stood a dense pine wood, a darksome, solemn place, where you went quietly. Now, not a pine is left. A mere wilderness of hardwood scrub. The old "cart-path," which at this point swerved to the left, has grown over till there is no following it. But the loss does not matter. You take a trail among the boulders, a trail familiar to you of old; the same that you took in 
winter, skates in hand, bound for Jason Halfbrook's meadow. Many a merry hour you spent there, heedless of the cold. You could skate then, or thought you could. The backward circle, the "Dutch roll," the "spread-eagle," these and other wonders were in your repertory. They were feats to be proud of, and you made the most of them. Nor need you feel ashamed now at the recollection. When the Preacher said, "There is nothing better than that a man should rejoice in his own works," he was not thinking exclusively of an author and his books. You did well to be proud while you were able. It was pride, in part, that kept you warm. Now, if you stand beside a city skating-resort, you see young fellows performing feats that throw all your old-fashioned, countrified accomplishments into the shade. You look on, openmouthed. Boys of to-day have better skates than you had. Perhaps they have better legs. One thing they do not have, - a better time.

This morning, however, you are not going to the Halfbrook meadow. There is no ice, or none that will bear a man's weight; and 
perhaps you would not skate if there were. Do I take you to be too old? No, not that; but you are out of practice. I should hate to see you risking yourself well over on the outer edge, or attempting a sudden turnabout. And you agree with me, I imagine, for you quit the trail at the Town Path (the compositor will please allow the capitals - the path deserves them) and turn your steps northward. The path, I say, deserves a proper name. It is not strictly a highway, I am aware; if you were to stumble into a hole here, the town could not be held liable for damages; but it is a pretty ancient thoroughfare, nevertheless, a reasonably straight course through the woods by the long way of them. Generation after generation has traveled it. You are walking not only in your own footsteps, but in those of your ancestors, who must have gone this way many a time to speak and vote at town meeting. Some of the oldest of them are buried in this very wood, less than half a mile back; a resting-place such as you would like pretty well for yourself when the time comes.

You follow the path till it brings you near 
to a cliff. This is one of the places you had in your eye on setting out. This land is yours, and you have come to look at it.

A strange thing it is, an astonishing impertinence, that a man should assume to own a piece of the earth; himself no better than a wayfarer upon it; alighting for a moment only; coming he knows not whence, going he knows not whither. Yet convention allows the claim. Men have agreed to foster one another's illusions in this regard, as in so many others. They knew, blindly, before any one had the wit to say it in so many words, that "life is the art of being well deceived." And so they have made you owner of this acre or two of woodland. All the power of the State would be at your service, if necessary, in maintaining the title.

These tall pine trees are yours. You have sovereignty over them, to use a word that is just now sweet in the American mouth. You may do anything you like with them. They are older than you, I should guess, and in the order of nature they will long outlive you; for aught I know, also, it may be true, what Thoreau said (profanely, as some thought), 
that they will go to as high a heaven; but for the time being they have no rights that you are under the slightest obligation to consider. You may kill them to-morrow, and nobody will accuse you of murder. You may turn all their beauty to ashes, and it will be nobody's business to remonstrate. The trees are yours.

I hope, notwithstanding, that you do not quite think so. I would rather believe that you look upon your so-called proprietorship as little more than a convenient legal fiction; of use, possibly, against human trespassers, but having no force as against the right of the trees to live a tree's life and fulfill a tree's end.

One of them, I perceive, is dead already. Like many a human being we have known, it had a poor start; no more than "half a chance," as the saying goes. It struck root on a ledge, in a cleft of rock, and after a struggle of twenty or thirty years has found the conditions too hard for it. Its neighbors all appear to be doing well, with the exception of one that had its upper half blown away a few years ago by a disrespectful 
wind. The wind is an anarchist; it bloweth where it listeth, with small regard for human sovereignty.

Your land, to my eye, is of a piece with all the land round about; or it would be, only for its tall gray cliff. That is indeed a beauty, a true distinction; not so tall as it was forty or fifty years ago, of course, but still a brave and picturesque sight. I should like the illusion of owning a thing like that myself. And the brook just beyond, so narrow and so lively, - that, too, you may reasonably be proud of, though it is nothing but a wet-weather stream, coming from the hill and tumbling musically downward into Dyer's Run, past one boulder and another, from late autumn till late spring, and then going dry. You have only pleasant memories of it, for you were oftenest here in the wet season. It has always been one of your singularities, I remember, to be less in the woods in summer than at other times.

Now you have crossed your own boundary; but who would know it? You yourself seem not to feel the transition. The wood is one; and really it is all yours, as it is any man's 
who has eyes to enjoy it. Appreciation is ownership.

So you go on, pausing here and there to admire a lichen-covered boulder or stump (there is nothing prettier, look where you will), a cluster of ferns, a few sprouts of holly, a sprinkling of pyrola leaves (green with the greenness of all the summers of the world), or a bed of fruit-bespangled partridge-berry vine, till by and by you begin to feel the overshadowing, illusion-dispelling, soul-absorbing presence of the wood itself. The voice of eternity is speaking in the pine leaves. Your own identity slips away from you as you listen. You are part of the whole; nay, you are not so much a part of it as lost in it. The raindrop has fallen into the sea. For a moment you seem almost to divine a meaning in that bold, pantheistical, much neglected scripture, "That God may be all in all."

For a moment only. Then a cord snaps, and you come back to your puny self and its limitations. You are looking at this and that, just as before. A chickadee chirps, and you answer him. You are you again, a man 


\section{IN THE OLD PATHS}

who used to be a boy. These are the old paths, and you are still in the body. You will prove it an hour hence at the dinnertable. 


\section{THE PROSPERITY OF A WALK}

A BIRD lover's daily rations during a New England winter are somewhat like Robinson Crusoe's on his island in the wet season. "I eat a bunch of raisins for my breakfast," he says, "a piece of goat's flesh or of the turtle for my dinner, and two or three of the turtle's eggs for my supper." Such a fare was ample for health, perhaps ; and probably every item of it was sufficiently appetizing, in itself considered; but after the first week or two it must have begun to smack of monotony. The castaway might have complained with some of old, "My soul loatheth this light bread." $\mathrm{He}$ might have complained, I say; I do not remember that he did. What I do remember is that when, moved by pious feeling, he was on the point of thanking God for having brought him to that place, he suddenly restrained himself, or an influence from without restrained him. 
"I know not what it was," he says, " but something shocked my mind at that thought, and I durst not speak the words. "How canst thou be such a hypocrite ?' said I."

So I imagine that most bird-gazing men would hesitate to thank the Divine Providence for a northern winter, with its rigors, its inordinate length, and its destitution. They put up with it, make the best of it, grumble over it as politely as may be; but they are not so piously false-tongued as to profess that they like it.

By the last of December they have begun, not exactly to tire of chickadees and blue jays, but to sigh for something else, something to go with these, something by way of variety. "Where are the crossbills," they ask, "and the redpoll linnets, and the pine grosbeaks?" All these circumpolar species are too uncertain by half, or, better say, by two thirds. Summering at the apex of the globe, so to speak, with Europe, Asia, and America equally at their elbow, they seem to flit southward along whatever meridian happens to take their fancy. Once in a while chance brings them our way, but only 
154 THE CLERK OF THE WOODS

once in a while. Last winter we had redpolls and both kinds of crossbills, the white-wings for the first time in many years. They made a bright season. This winter, to the best of my knowledge, not one of these hyperborean species has sent so much as a deputation for our enlivenment.

And to make matters worse, even our regular local stand-bys seem to be less numerous than usual. Tree sparrows and snowbirds are both abnormally scarce, by my reckoning. As for the Canadian nuthatches, which helped us out so nobly a year ago, they are not only absent now, but were so throughout the fall. I have not seen nor heard one in Massachusetts since the middle of May, a most unusual - to the best of my recollection a quite unprecedented - state of things. I should like very much to know the explanation of the mystery.

The daily birds at present, as I find them, are the chickadee (which deserves to head all lists), the Carolina nuthatch, the downy woodpecker, the crow, and the jay. Less regularly, but pretty frequently (every day, if the walk is long enough), one meets with 
tree sparrows, goldfinches, snowbirds, brown creepers, flickers, and golden-crowned kinglets. Twice since December came in $\mathrm{I}$ have seen a shrike. Once I heard a single pine finch passing, invisible, far overhead. On the same day (December 2) I caught the fine staccato calls of a purple finch, without seeing the author of them. On the $2 \mathrm{~d}$ and $3 \mathrm{~d}$ three or four rusty blackbirds were unexpectedly in the neighborhood. Quail and grouse are never absent, of course, but I happen to have seen neither of them of late, though one day I heard the breezy quoiting of a quail, greatly to my pleasure. On the 14 th I came upon a single robin in the woods, the first since November 21. He was perched in a leafless treetop, and was calling at the top of his voice, as if he had friends, or hoped that he had, somewhere within hearing. The sight was rather dispiriting than otherwise. He looked unhappy, in a cold wind, with the sky clouded. He had better have gone south before this time, I thought. Half an hour afterward I heard the quick, emphatic, answer-demanding challenge of a hairy woodpecker (as much louder and sharper than the 
downy's as the bird is bigger), and on starting in his direction saw him take wing. Him I should never think of commiserating. He can look out for himself. These, with English sparrows ("the poor ye have always with you "), Old Squaws, herring gulls, and loons, make up my December list of twenty-two species. It might be worse, I suppose. I remember the remark of a friend of mine on a similar occasion. "Well," said he, "the month is only half gone. You ought to see as many more before the end of it." He was strong in arithmetic, but weak in ornithology. If bird lists could be made on his plan, we should have our hands full in the dullest season. Even in January, I would engage to find more than three hundred species within a mile of my doorstep.

As matters are, we must come back (we cannot do so too often, in winter especially) to the good and wholesome doctrine that pleasure is not in proportion to numbers or rarity. It depends upon the kind and degree of sympathy excited. One day, in one mood, you will derive more inspiration from a fiveminute chat with a chickadee than on another 
day, in some mood of dryness, you would get from the sight of nightingales and birds of paradise. Worldlings and matter-of-fact men do not know it, but what quiet nature lovers (not scenery hunting tourists) go to nature in search of is not the excitement of novelty, but a refreshment of the sensibilities. You may call it comfort, consolation, tranquillity, peace of mind, a vision of truth, an uplifting of the heart, a stillness of the soul, a quickening of the imagination, what you will. It is of different shades, and so may be named in different words. It is theirs who have the secret, and the rest would not divine your meaning though your speech were transparency itself.

To my thinking, no one, not even Thoreau, or Jefferies, or Wordsworth, ever said a truer word about it than Keats dropped in one of his letters. Nothing in his poems is more deeply poetical. "The setting sun will always set me to rights," he says, "or if a sparrow come before my window, I take part in his existence and pick about the gravel." There you have the soul of the 


\section{THE CLERK OF THE WOODS}

matter. "I take part in his existence." When you do that, the bird or the flower may be never so common or so humble. Your walk has prospered. 


\section{SIGNS OF SPRING}

THeY are not imaginary, but visible and tangible. I have brought them home from the woods in my hands, and here they lie before me. I call them my books of the Minor Prophets.

This one is an alder branch. Along its whole length, spirally disposed at intervals of an inch or two, are fat, purplish leafbuds, each on its stalk. As I look at them I can see, only four months away, the tender, richly green, newly unfolded, partly grown leaves. How daintily they are crinkled! And how prettily the edges are cut! It is like the work of fairy fingers. And what perfection of veining and texture! I have never heard any one praise them; but half the things that bring a price in florists' shops are many degrees less beautiful.

Still more to the purpose, perhaps, more conspicuous, at all events, as well as nearer 
to maturity, and so more distinctly prophetic of spring, are the two kinds of flower-buds that adorn the ends of the twigs. These also are of a deep purplish tint, which in the case of the larger (staminate) catkins turns to a lovely green on the shaded under side. Flower-buds, I call them; but they are rather packages of bud-stuff wrapped tightly against the weather, cover overlapping cover. The best shingling of the most expert carpenter could not be more absolutely rain-proof. "Now do your worst," says the alder. The mud freezes about its roots and the water about the base of its stem, but it keeps its banners flying. Why it should be at such pains to anticipate the season is more than I can tell. Perhaps it is none of my business. Enough that it is the alder's way. There is no swamp in New England but has a shorter and brighter winter because of it.

This smooth, freckled, reddish-barked twig is black birch (or sweet birch), taken from a sapling, and therefore bearing no aments, which on adult trees are already things of grace and promise. I broke it 
(it invites breaking by its extreme fragility) for its leaf-buds, pointed, parti-colored, brown and yellowish green, - tender-looking, but hardy enough to withstand all the rigors of New England frost. The broken end of the branch, where I get the spicy -fragrance of the inner bark, brings back a sense of half-forgotten boyish pleasures. I used to nibble the bark in spring. A little dry it was, as I remember it, but it had the spicy taste of wintergreen (checkerberry), without the latter's almost excessive pungency, or bite. Some of my country-bred readers must have been accustomed to eat the tender reddish young checkerberry leaves, and will understand perfectly what I mean by that word " bite." I wonder if they had our curious Old Colony name for those vernal dainties. It sounds like cannibalism, but we gathered them and ate them in all innocence (the taste is on my tongue now) as "youngsters." No doubt the tree gets its name, "sweet birch," from this savoriness of its green inner bark, rather than from the pedagogic employment of its branches in schoolrooms as a means of promoting the sweet uses of adversity. 
Now I take up another freckled, easily broken twig, with noticeably short branchlets, some of them less than an inch in length. Every one, even the shortest, is set with brown globular buds of the size of pinheads. Toward the tip the main stem also bears clusters of such tiny spheres. If you do not know the branch by sight, I must ask you to smell or taste the bark. "Sassafras?" No, though the guess is not surprising. It is spice-bush. The buds are flowerbuds. The shrub is one of our very early bloomers, and makes its preparations accordingly. While flowers are still scarce enough to attract universal attention, it is thickly covered with sessile or almost sessile yellow rosettes, till it looks for all the world like the early-flowering cornel (Cornus Mas), which blossoms about the same time in gardens. Seeing these spice-bush buds, though January is still young, I can almost see Mayday; and when I snap the brittle stem and sniff the fresh wood, I can almost believe that I have snapped off half a century from my life. What a good and wholesome smell it is ! Among the best of nature's own. 
Here is a poplar twig, with well-developed, shapely buds. I pull off the outer coverings and lay bare a mass of woolly fibres, fine and soft, within which the tender blossoms lie in germ. And next is a willow stem. Already, though winter is no more than a fortnight old, the "pussy" has begun to push off its dark coverlid, as if it were in haste to be up and feel the sun. Yes, spring will soon be here, and the willow proposes not to be caught napping.

These long, slender, cinnamon-colored, silky buds, like shoemakers' awls for shape, are from a beech tree. The package is done up so tightly and skillfully that my clumsy human fingers cannot undo it without tearing it in pieces. Layer after layer I remove, taking all pains, and here at the heart is the softest of vegetable sillk. How did the wood learn to secrete such delicacies, and to wrap them with such miraculous security? Why could it not wait till spring, and save the need of all this caution? I do not know. How should I? But I am glad of every such vernal prophecy, as well as of every such proof of vegetable intelligence. It 
164 THE CLERK OF THE WOODS

would be strange if a beech tree could not do some things better than you and I can. Every dog knows his own trick.

Next comes a dry, homely, crooked, blackish, dead-looking twig, the slender divisions of which are tipped with short clusters of very fine purplish buds, rich in color, but so small as readily to escape notice. This I broke from a bush in a swampy place. It is Leucothöe, a plant of special interest to me for personal reasons. Year after year, as I turned the leaves of Gray's Manual on one errand and another, I read this romantic-sounding Greek name, and wondered what kind of plant it stood for. Then, during a May visit to the mountains of North Carolina, I came upon a shrub growing mile after mile along roadsides and brooksides, loaded down, literally, with enormous crops of sickishly sweet, white flower-clusters. At first I took it for some species of Andromeda, but on bringing it to book found it to be Leucothoë. I was delighted to see it. It is a satisfaction to have a familiar name begin to mean something. Finally, a year or two later, passing in winter through a bit of 
swamp where I had been accustomed to wander as a child, with no thought of finding anything new (as if there were not something new everywhere), I stopped before a bush bearing purple buds and clusters of dry capsules. The capsules might have been those of Andromeda, for aught I should have noticed, but the buds had a novel appearance and told a different story. Again I betook myself to the Manual, and lo! this bush, growing in the swamp that I should have thought I knew better than any other in the world, turned out to be another species - our only northern one - of Leucothoë. So I might have fitted name and thing together long ago, if I had kept my eyes open. As Hamlet said, "There's the rub." Keeping one's eyes open is n't half so easy as it sounds. Really, the bush is one that nobody except a botanist ever sees (which is the reason, doubtless, why it has no vernacular name); or if here and there a man does see it, it is sure to be in flowering time (in middle June), when he passes it by without a second glance as " high-bush blueberry." I am pleased to have it grow- 
ing on my present beat, and to give it a place here in my collection of Minor Prophets.

How little the two (Leucothoë and blueberry) resemble each other at this time of the year may be seen by comparing the stem I have been talking about with the one lying next to it - a short twig, every branchlet of which ends in a very bright, extremely handsome (if one stops to regard it) pinkish globe. This is the high-bush blueberry in its best winter estate. Every bud is like a jewel.

Only one branch remains to be spoken of, for I took but a small handful : a dark green - blackish-green - tarnished stem, the two branches of which bear each a terminal bud of the size of a pea. This specimen you will know at once by its odor, if you were ever happy enough to dig sassafras roots, or to eat sassafras lozenges, such as used to come - perhaps they do still - rolled up in paper, as bankers roll up coins. "Sassafras lossengers," we called them, and the shopkeeper (who is living yet, and still "tending store" at ninety-odd) seemed never in doubt as to what we meant. Each kind of lozenge, 
peppermint, cayenne, checkerberry, and the rest, came always in paper of a certain color. Can I be wrong in my recollection of the sassafras tint? I would soon find out if I could go into the old store. I would lay five cents upon the counter (the price used to be less than that, but it may have gone up since my last purchase), and say, "A roll of sassafras lossengers." And I miss my guess, or the wrapper would be yellow. 1

1 How fallible a thing is a man's memory! The wrapper was not yellow, but green. Yellow was for lemon. So more than one friendly correspondent has made haste to inform me, and the venerable shopkeeper himself has sent me a roll of the "lossengers" to prove it. My compliments to him. 


\section{OLD COLONY BERRY PASTURES}

THE last holiday of the century found me in the place where $I$. was born, with weather made on purpose for out-of-door pleasures warm, bright, and still. A sudden inspiration took me. I would go to see the old berry pastures - not all of them (the forenoon would hardly be long enough for that), but two or three of the nearest, on opposite sides of the same back road. It would be a kind of second boyhood.

As I traveled the road itself, past two or three houses that were not there in the old time, two at least of the older wayside trees greeted me with the season's compliments. Or possibly it was I that greeted them. In this kind of intercourse, it is hard to tell speaker from hearer. We greeted each other, let us say, though they are the older, and by good rights should have spoken first. They have held their own exceedingly well, 
far better than the clerk who is writing about them, and for anything that appears, bid fair to be hale and hearty at the next centurymark.

One is a pear tree; none of your modern, high-bred, superfine, French-named dwarfs, rather shrubs than trees, twenty of which may grow, without crowding, in a scanty back garden, but a burly, black-barked, stubbybranched, round-topped giant. It looks today exactly as it did when my boyish legs first took me by it. In these many years it has borne thousands of bushels of pears, all of which must have served some use, I suppose, in the grand economy of things, though I have no idea what. No man, woman, or child, I am reasonably sure, ever had the hardihood to eat one. And still the tree holds up its head and wears a brave, unashamed, undiscourageable look. Long may it stand in its corner, a relic and remembrancer of Puritanic times.

The other is an apple tree, one of those beneficent creations, good Samaritans among fruit trees, that bear a toothsome, early-ripening crop, and spill a generous portion of it 
on the roadward side of the wall. I remember it perfectly - the fruit, I mean - color, shape, and flavor. Every year I see apples of the same name in the market, but somehow I can never buy any that look or taste half so good as those that I used in lucky moments to find here, waiting for me, in the roadside grass.

Those were Old Testament times in New England. Gleanings belonged to "the poor and the stranger." Who could dispute our title? We believed in special providences; and edible windfalls on the nigh side of the fence were among the chiefest of them. Schoolboys of the present day, I take for granted, are brought up under a different code. They would go past such temptations with their hands in their pockets and without a squint sideways. They apprehend no difference between "picking up" an apple and stealing one. Such is the evolution of morality. The day of the gleaner is past. Naomi and Ruth have become mythical personages, as much so as Romulus and Remus.

I was going first to Harvey White's pasture (not to dwell unsafely upon confessions 
that begin to seem like thin ice), and by and by came to the wood-path leading to it. How perfectly I remembered the place: this speedy, uphill curve to the left, rounding the hill ; this dense bunch of low-branched evergreens a little farther on, under which, with our pails full (or half full - we could not work miracles, though we lived under the Mosaic economy), we used to ereep for rest and shade while trudging homeward on blazing summer noons. But the path was surprisingly overgrown. At short intervals thorny smilax vines (cat-briers) were sprawling over the very middle of it, and had to be edged through eautiously. The appearance of things grew less and less familiar. I must be on the right track, but surely I had gone far enough. The broad clearing should be close at hand. I went on and on. Yes, here was the old stone wall between Harvey White's pasture and Pine-tree pasture. But the pastures themselves? They were not here. Then it came over me, with all the force and suddenness of a direct revelation, that forty years is a long time. In less time than that a pasture may become a forest. I 
pushed about a little, in one direction and another, and finding nothing but woods, returned to the path and retraced my steps. I might as well try to find my own lost youth as those well-remembered huckleberry patches.

Even in that far-away time - so the recollection comes to me now - the place was not strictly a pasture. It had been such, no doubt, and Harvey White, whoever he was, had owned it. Probably his cattle had once been pastured there. Now he owned no land, being nothing but a clod himself, and this broad clearing would not have kept a single cow from starvation. The wilderness was claiming its own again. Instead of the grass had come up the huckleberry bushes, the New England heather. These, with a sprinkling of blackberry vines, barberry bushes, and savins, filled the place from end to end. We knew them all. In the season we gathered huckleberries, blackberries, and barberries (the last made what some gastronomic cobbler called felicitously "shoe-peg sauce"), while the young cone-shaped cedars were of use as landmarks. We could leave a pail or basket in the shelter of one, and with good 
luck have no great difficulty in finding it again.

That was forty years ago. Now, the huckleberry bushes have followed the grass. Massachusetts land belongs to the woods. Clear it never so thoroughly, and with half a chance the trees will have it back again. If you will climb any Massachusetts hill, not directly upon the seashore, - and I am not certain that even that exception need be made, - you will see the truth of this at once. Something like it, I remember, was the first thing I thought of when I stood first on Mount Wachusett. There lay the whole State, so to speak, outspread below; and it was all a forest.

In this very Old Colony town many acres that were once excellent pasturage are now so perfectly reconverted to woodland that no ordinary walker over them would suspect that they had ever been anything else. If this has happened within twenty miles of Boston, within half the lifetime of a man, there seems to be no great danger that the State will ever be deforested; and those of us who love wild things, and look upon civ- 
ilization as a mixed good, may be cheered accordingly,

For to-day, however, I had something else in my eye; and once back in the road I started for the entrance to what we children knew familiarly as "Millstone" - that is to say, Millstone Pasture; a large, irregular clearing, or half clearing, distinguished by the presence of two broad flat boulders, lying one upon the other. This was among the best of our foraging grounds; a boy's wild orchard - orchard and garden in one. Here we gathered all the berries before named, and besides them checkerberries (boxberries), dangleberries, and grapes.

The path leading into it was still open, but there was no need to go far to discover that here, as in Harvey White's, the wood had got the upper hand of everything else. "I should starve here," I said to myself, " at the very height of the berry season." Nothing looked natural — nothing but the superimposed boulders. They had suffered no change, or none except an inevitable "subjective" dwindling. As for the old apple orchard near them (in which I shot 
OLD COLONY BERRY PASTURES 175

my last bird upwards of twenty years ago), it was more like a cedar grove, although by searching for them one could still discover a few stumps and ruins of what had once been apple trees. "Perish your civilization!" Mother Nature seemed to be saying. "Give me a few years, and I will undo the whole of it." I was half glad to hear her. The planter of the orchard was dead long ago, and his work had followed him.

But the holly trees! They are Nature's own children. I would have a look at them, remembering perfectly, I thought, the exact spot where a pretty bunch used to grow. And I found them, after a protracted search - but no longer a pretty clump. One tree was perhaps fifteen feet high - a - beanpole, which still put forth at the very top a few branchlets, one or two feet in length, just to prove itself alive. The rest of the bunch had been cut down to the ground. All that remained was a few suckers, each with a spray of green leaves. The sight was pitiful. Poor trees! They were surrounded by a dense wood, instead 


\section{THE CLERK OF THE WOODS}

of standing in the open, as they had done in my day. And between the competition of the pines and the knives and axes of collectors of Christmas greenery, they were nigh to extermination. By and by, however, before many years, the pines will fall under the axe. Then, I dare say, the old holly roots will have their turn again. Then, too, the checkerberry vines will enjoy a few years of fruitfulness. So the wheel of fortune goes round, all the world over, in the wood no less than in the city. There is no scotehing it. As well try to scotch the earth itself. All things are at seesaw.

"They say the lion and the lizard keep

The courts where Jamshyd gloried and drank deep;

And Bahram, that great hunter - the wild ass Stamps o'er his head, but cannot break his sleep."

If such things have happened, if Nineveh and Babylon flourished and came to naught, why wonder at the decline and fall of Old Colony berry pastures? 


\section{SQUIRRELS, FOXES, AND OTHERS}

"Do you know where there are any flying squirrels?" I asked a friend, two or three weeks ago. My friend, I should mention, is a farmer, living a mile or two away from the village, and, being much out of doors with his eyes open, has sometimes good things to show me. With all the rest, he has more than once taken me to a flying squirrel's tree and given me a chance to see the creature "fly."

This peculiar member of the squirrel family, as all readers may be presumed to know, is nocturnal in its habits, and for that reason is seldom seen by ordinary strollers. Once my friend, who was just then at work in the woods, found a hollow tree in which one was living, and we visited the spot together. I posted myself conveniently, and he went up to the tree and hammered upon it with his axe. Out peeped the squirrel at 
a height of perhaps twenty feet, and as the blows continued it "took wing" and came to the ground safely, and more or less gracefully, alighting at the foot of another tree some distance away. At all other times I have seen the flight from outside nests, as they may be called — bulky aggregations of leaves and twigs placed in the bare tops of moderately tall, slender trees, preferably gray birches, and mostly in swampy woods.

On the present occasion my friend told me that he knew of no nests now in use, but that if I would come to his house the next morning he would go with me in search of some. I called for him at the hour appointed. Squirrels or no squirrels, it is always worth while to take a walk in good company.

He led me along the highway for a quarter of a mile, and then struck into a woodroad, which presently brought us into a swampy forest, with here and there a bit of pond, which we must go out of our way to cross on the ice (a light snow had covered it within twenty-four hours), on the lookout for fox tracks and what not. We were 
SQUIRRELS, FOXES, AND OTHERS 179

headed for the "city-house lot," he told me.

"The city-house lot," said I; "what is that?"

"Why, there used to be two or three houses over in this direction. The largest of them, the one that stood the longest, was known as the city house. More than fifty years ago, before my father camo here to live, it was moved to a place on the main road. You must remember it. It was pulled down, or fell to pieces, within six or eight years."

I did remember it, but had never known its name or its history. The surprising thing about the story was the fact that there was no indication of a road hereabout, nor any sign that there had ever been one; and all the while we were plunging deeper and deeper into the woods, now following a footpath, now leaving it for a short cut among the trees. By and by we came to a drier spot, and an old cellar-hole. This was not the city-house cellar, however, but that of some smaller house. About it were evidences of a former clearing, though a casual 
observer would scarcely have noticed them. Tufts of beard-grass stood above the snow, "Indian grass," my guide called it, - and the remains of an ancient stone wall still marked the line, if one might guess, where the grazing-land had been divided from the tillage. It was a farm in ruins.

Soon we came to a larger cellar-hole, of which, as of the smaller one, bushes and trees had long ago taken possession. Here had stood the city house, a "frame" structure (whence its name, probably), a famous affair in its day, the pride of its owner's heart. It was one of five or six houses, if I understood my informant correctly, that had once been scattered over this part of the town of Weston (or what is at present the town of Weston) within a radius of a mile or so. Of them all not a trace remains now but so many half-filled cellars.

I thought of something I had been saying lately about the manner in which the forest reclaims Massachusetts land as soon as its human possessors let go their hold upon it. Now it was suggested to me that if a man is ambitious to do something that will last, he 
had better not set up a house or a monument, but dig a hole in the ground. Humility helps to permanence. The lower you get, the less danger of falling. Nature is slower to fill up than to pull down, though she will do either with all thoroughness, give her time enough. To her a man's life is but a clock's tick, and all his constructions are but child's play in the sand. A trite bit of moralizing? Well, perhaps it is; but it sounded anything but trite, as the old cellar-hole spoke it to me. A word is like a bullet: its force is in the power behind it.

Not far beyond this point we found ourselves in a gray-birch swamp. Here, if anywhere, should be the nests we were in search of. And soon we began to see them, one here, another there. We followed the same course with them all; my companion shook or jarred the tree, while I stood off and watched for the squirrels. And the result was alike in all cases. Every nest was empty. We tried at least a score, and had our labor for our pains. "There are no flying squirrels this year," my companion kept saying. Perhaps they had migrated. 
With one or two exceptions, indeed, the nests could be- set down in advance-from their color and evident dilapidation - as being at least a year old.

Once we started a rabbit, and here and there a few chickadees accosted us. Once, I think, we heard the voice of a goldencrowned kinglet. For the rest, the woods seemed to be deserted, and at the end of our long détour we came back to the road half a mile above the point at which we had left it.

And still the world is not depopulated, even in winter, nor are all the pretty wild animals asleep. The snakes are, to be sure, and the frogs (though hylas were peeping late in December), and the chipmunks and the woodchucks; but there is abundant life stirring, nevertheless.

Yesterday I called on my friend again, and together we walked up the road-a back-country thoroughfare. This time, also, a light snow had just fallen, and my companion, better informed than $I$ in such matters, began to discuss footprints with me.

"You know this one?" he asked. 
SQUIRRELS, FOXES, AND OTHERS 183

"Oh, yes; a rabbit."

"And this one?"

"A fox," said I, doubtfully.

"Yes, indeed. See the shape and size of the foot. Yes, that's a fox."

"And this one?"

"Oh, that's a kitty." (A cat, he meant to say.) "Strange how many cats are prowling about this country at night," he continned. "I have caught two this season, and C__ has caught two."

"Do you skin them?"

"Yes," with a laugh.

Here were red-squirrel tracks, and here a big dog's, and here again a fox's. At another point a bevy of quail had crossed the road. "One, two, three," my farmer began to count. "Yes; there were twelve." I had remarked, just before, that I had n't seen a quail for I did n't know how long. " And look here," he said, as we approached the farm on our return. He led the way to a diminutive chicken-coop sitting by itself in the orchard. A single hen, which had been ailing, was confined in it, he said. A fox had gone round and round it in the night, 
and once had stopped to scratch at the back side of it.

"He knew what was in there," said I. The farmer laughed.

"Oh, he is an old fellow," he answered. "I have a trap set for him just where he used to pass. Now he crosses the field, but he goes round that spot! I see his tracks. They say it is easy to trap foxes. Perhaps it is ; but it is n't for me."

Yet he has shown me - not this year more than one handsome skin.

Once, too, he showed me the fox himself. Hounds were baying in the distance as I came to the house on my Sunday morning walk, and we spoke of their probable course. He thought it likely that they would cross a certain field, and taking a by-road that would carry us within sight of it, we kept our eyes out till the dogs seemed to have diverged in the wrong direction. Then I was walking carelessly along, talking as usual ( $a$ bad habit of mine), when my companion seized me by both shoulders and swung me sharply about. "Look at that!" he said. And there stood the fox, five or ten 
SQUIRRELS, FOXES, AND OTHERS 185

rods away, facing us squarely. He had come up a little rise of ground, and had stopped as he saw us. But for my friend's muscular assistance, I should have missed him, near as he was, for in one second he was gone; and though we scaled the wall instantly and ran up the slope, we got no further sight of him.

Yes, if you are a discouraged, winter-killed nature lover, who has begun to think that Massachusetts woods - woods within sight of the State House dome - are pretty much devoid of wild life, go out after a light snowfall and read the natural history record of a single night. We shall not be without woods, nor will the woods be without inhabitants, for a good while yet. 


\section{WINTER AS IT WAS}

WrTH the wind howling from the northwest, and the mercury crouching below the zero mark, it seems a good time to sit in the house and think of winter as it used to be. What is the advantage of growing old, if one cannot find an hour now and then for the pleasures of memory?

The year's end is for the young. Such is the order of the world, the universal paradox. Opposite seeks opposite. And we were young once, - a good while ago, - and for us, also, winter was a bright and busy season, its days all too short and too few. I speak of "weekdays," be it understood. As for winter Sundays, in an unwarmed meeting-house (though the sermon might be like the breath of Nebuchadnezzar's furnace), we should have been paragons of early piety, beings too good to live, if we had wished the hours longer. Let their miseries be forgotten. 
On week-days, once out of school, we wasted no time. We knew where we were going, and we went on the run. We were boys, not men. Some of us, at least, were not yet infected with the idea that we ever should be men. We aspired neither to men's work nor to men's pleasures. We aimed not at self-improvement. We thought not of getting rich. We might recite " Excelsior" in the schoolroom, but it did us no harm; our innocence was incorruptible. Two things we did: we skated, and we slid down-hill. There was always either snow or ice. The present demoralization of the seasons had not yet begun. Winter was winter. Snowdrifts were over your head, and ice was three feet thick. And zero for boys who slept in attics to which no particle of artificial heat ever penetrated, zero was something like summer. Young America was tough in those days.

I recall at this moment the bitterly cold day when one of our number skated into an airhole on Whitman's Pond. It was during the noon recess. His home was a mile or more east of the pond, and the schoolhouse 
was at least a mile west of the pond. He sank into the water up to his chin, and saved himself with difficulty, the airhole luckily being small and the ice firm about the edges. What would a twentieth-century boy do under such circumstances? I can only guess. But I know what Charles $H$. did. He came back to the schoolhouse first, to make his apologies to the master; I can see him now, as he

- came in smiling, looking just a little foolish ; then he ran home - three miles, perhaps to change his clothing. And he is living still. $\mathrm{Oh}$, yes, we were tough, - or we died young.

That was while we were in the high school, when I was perhaps eleven or twelve years old. But my liveliest recollections of winter antedate that period by several years. Then sliding down-hill was our dearest excitement. Ours was " no great of a hill," to use a form of speech common among us; I smile now as I go past it; but it could not have suited us better if it had been made on purpose; and no half holiday or moonlight evening was long enough to exhaust our enjoyment of the exercise - walking up and sliding down, walking up and sliding down. "Mo- 
notonous," do I hear some one say? It was monotony such as would have ended too soon though it had lasted forever. If I had a thousand dollars to spend in an afternoon's sport now, I should not know how to get half as much exhilaration out of it as two hours on that snow-covered slope afforded. There is 'something in a boy's spirits that a man's money can never buy, nor a man's will bring back to him.

As years passed, we ventured farther from home to a steeper and longer declivity. Glorious hours we spent there, every boy riding his own sled after his own fashion. Boys who were boys rode "side-saddle" or "belly-bump;" but here and there a timid soul, or one who considered the toes of his boots, condescended to an upright position, feet foremost, like a girl - in the language of the polite people, sur son séant.

Later still came the day of the doublerunner, when we slid down-hill gregariously, as it were, or, if you will, in chorus (the word is justified), every boy's arms clinging to the boy in front of him. Older fellows now took a hand with us, and we resorted 
to the highway. With the icy track at its smoothest, we went the longer half of a mile, and had a mile and a half to walk back, the "going" being slippery enough to double the return distance.

At this time it was that there came a passing rage (such as communities are suddenly taken with, now and then, for a certain amusement - golf, croquet, or what not) for coasting in a huge pung. Grown people, men and women, filled it, while one man sat on a hand-sled between the thills and guided its course. Near the foot of the hill the road took a, pretty sharp turn, with a stone wall on the awkward side of the way; but the excitement more than paid for the risk, and by sheer good luck a thaw intervened before anybody was killed.

There was quiet amusement in the neighborhood, I remember, because Mrs. C., who was distressingly timid about riding behind a horse (she could never be induced to get into a carriage unless the animal were "old as Time and slow as cold molasses"), saw no danger in this automobile on runners, which traveled at the rate of a mile a min- 
ute, more or less, with nothing between its occupants and sudden death except the strength and skill of the amateur steersman, who must keep his own seat and steer the heavy load behind him. So it is. A man goes into battle with a cheer, but turns pale at finding himself number thirteen at the dinner-table.

Sliding down-hill was such sport as no language can begin to describe ; but skating was unspeakably better. Those first skates! I wish I had them still, though I would show them with caution, lest the irreverent should laugh. They would be a spectacle. How voluminously the irons curled up in front! And how gracefully as well! A piece of true artistry. And how comfortably they were cut off short behind, so that you could stop " in short metre," no matter what speed you had on, by digging your heels into the ice. And what a complicated harness of straps was required to keep them in place. Those straps had much to answer for in the way of cold feet, to say nothing of the passion we were thrown into when one of them broke; and we a mile or two from 
home, with the ice perfection - " a perfect glare" - and the fun at its height. This was before the day of "rockers," of which I had a pair later, - and a proud boy I was. Pretty treacherous we found them to start with, or rather to stop with; but for better or worse we got the hang of their peculiarities before our skulls were irreparably broken.

Skating then was like whist-playing now, - an endless study. You thought you were fairly good at it till a new boy came along and showed you tricks such as you had never dreamed of ; just as you thought, perhaps, that you could play whist till you sat opposite a man who asked, in a tone between bewilderment and asperity, why on earth you led him a heart at a certain critical stage, or why in the name of common sense you did n't know that the ten of clubs was on your left. Art is long. It was true then, as it is now. But what matter? We skated for fun, as we did everything else (out of school), except to shovel paths and saw wood. Those things were work. And work was longer even than art. Work was 


\section{WINTER AS IT WAS}

never done. So it seemed. And how bleak and comfortless the weather was while we were doing it! A cruel world, and no mistake. But half an hour afterward, on the hillside or the pond, the breeze was just balmy, and life - there was no time to think how good we found it. No doubt it is true, as the poet said, -

"There's something in a flying horse, There's something in a huge balloon;"

but there's more, a thousand times over, in being a boy. 
"DOWN AT THE STORE"

I TALKED, a week ago, as if, in my time as a boy, we lived out of doors every day, and all day long, regardless of everything that winter could do to hinder us. That was an exaggeration. Now and then there came a time when the weather shook itself loose, as it were, and bore down upon us with banners flying. Then the strong man bowed himself, and even the playful boy took to his burrow. The pond might be smooth as glass, but he did not skate; the hilltrack might be in prime condition, but he did not slide. He sang low, and waited for a change.

Not that he stayed at home from school. Let no degenerate reader, the enfeebled victim of modern ideas, think that. The day of coddling had not yet dawned upon New England. There was no bell then to announce a full holiday, or "one session," 
because of rain or snow. And as truly as "school kept," so truly the boy was expected to be there. No alternative was so much as considered. But on such a morning as we now have in mind he went at full speed, looking neither to right nor left, and he thanked his stars when he came in sight of the village store. That, whether going or coming, he hailed as a refuge. Possibly he had a cent in his pocket, a real " copper," and felt it in danger of burning through; but cent or no cent, he went in to warm his fingers and his ears, and incidentally to listen to the talk of the assembled loafers.

I can see them now, one perched upon a barrel-head, one on a pile of boxes, three or four occupying a long settee, and one, wearing a big light-colored overcoat, who came every day, sitting like a lord in the comfortable armchair in front of the cylinder stove. This last man was not rich; neither was he in any peculiar sense a social favorite; he said little and bought less; but he always had the chief seat. I used to wonder what would happen if some day he should come 
in and find it occupied. But on that point it was idle to speculate. As well expect a simple congressman to drop into the Speaker's chair, leaving that functionary to dispose of his own corporeal dignity as best he could. Prescription, provided it be old enough, is the best of titles. What other has the new king of Great Britain and Ireland?

If it was shortly before schooltime, on one of those mornings when the weather seemed to be laying itself out to establish a record, the talk was likely to be of thermometers.

" My glass was down to nineteen below," one man would say, by way of starting the ball.

"Mine tonched twenty at half-past six," the next one would remark.

And so the topic would go round, the mercury dropping steadily, notch by notch. As I said a week ago, winter was winter in those days. It may have occurred to me, sometimes, that the man who managed to speak last had a decided moral advantage over his rivals. He could save the honor 
of his thermometer at the least possible expense of veracity.

So far things were not very exciting, though on the whole rather more so, perhaps, than studying a geography lesson (as if it were anything to me which were the principal towns in Indiana!); but now, not unlikely, the conversation would shift to hunting exploits. This was more to the purpose. Wonderful game had been shot, first and last, down there in the Old Colony; almost everything, it seemed to a listening boy, except lions and elephants. If $\mathrm{Mr}$. Roosevelt had lived in those times, he need not have gone to the Rocky Mountains in search of adventure.

I listened with both ears. There never was a boy who did not like to hear of doings with a gun. I remember still one of my very early excitements in that line. I was on my way home at noon when a flock of geese flew directly over the street, honking loudly. At that moment a shoemaker ran out of his little shop, gun in hand, and aiming straight upward, let go a charge. Nothing dropped, to my intense surprise 
198 THE CLERK OF THE WOODS

and no small disappointment; but I had seen the shot fired, and that was something - as is plain from the fact that I remember it so vividly these many years afterward. The names of the principal towns of Indiana long ago folded their tents like the Arabs and silently stole away, but I can still see that shoemaker running out of his shop.

It was a common practice, I was to learn as I grew older, for shoemakers to keep a loaded gun standing in a corner, ready for such contingencies. There was a tradition in the town that a certain man ( $I$ have forgotten his name, or I would bracket it with Mr. Roosevelt's) had once brought down a goose in this way. It is by no means impossible; for flocks of geese were an everyday sight in the season ( $\mathrm{I}$ am sure $\mathrm{I}$ have seen twenty in an afternoon), and sometimes, in thick weather, they almost grazed the chimney-tops. Geese (of that kind) have grown sadly fewer since then, and perhaps have learned to fly higher.

After the hunting reminiscences would likely enough come a discussion of fast horses, Flora Temple and others - includ- 
ing "Mart" So-and-So's of our village ; or possibly (and this I liked best of all, I think), the conversation would flag, and old Jason Andcut would begin whistling softly to himself. Then I was all ears. Such a tone as he had, especially in the lower register! And such trills and bewitching turns of melody! Why, it was almost as good as the Weymouth Band, which in those days was every whit as famous as the Boston Symphony Orchestra is now. When it played the "Wood-up Quickstep" or "Departed Days," the whole town was moved, and one boy that I knew was almost in heaven.

In fact, ours was a musical community. The very man who now occupied the armchair in front of the stove (how plainly he comes before me as I write, taking snuff and reading the shopkeeper's newspaper of the evening before) had acquired the competency of which he was supposed to be possessed by playing the flute (or was it the clarinet?) in a Boston theatre orchestra; and at this very minute three younger men of the village were getting rich in the same sure and easy 
manner. As for whistling, there was hardly a boy in the street but was studying that accomplishment, though none of them could yet come within a mile of Jason Andeut. His was indeed " a soft and solemn-breathing sound," as unlike the ear-piercing notes which most pairs of puckered lips gave forth as the luscious fruit of his own early pear tree ("Andcut's pears," we always called them) was unlike certain harsh and crabbed things that looked like pears, to be sure, but tied your mouth up in a hard knot if, in a fit of boyish hunger, you were ever rash enough to set your teeth in one. The good man! I should love to hear his whistle now; I believe I should like it almost as well as Mr. Longy's oboe; but the last of those magical improvisations was long ago finished. I have heard good whistling since (not often, but I have heard it, both professional and amateur), but nothing to match that soliloquistic pianissimo, which I stole close to the man's elbow to get my fill of. Was the prosperity of the music partly in the boyish ear that heard it?

That corner-grocery gathering was one 
of our institutions; I might almost say the chief of them - casino and lyceum in one. If somebody once called the place a "yarn factory," that was only in the way of a joke. On a rainy holiday it was a great resource. There were always talkers and listeners there, - the two essentials, - and the talk was often racy, though never, so far as I know, unfit for a boy's hearing. The town supported no local newspaper, nor did we feel the need of any. You could get all the news there was, and more too, "down at the store." If the regular members of the club failed to bring it in, the baker or the candy peddler would happen along to supply the lack. And after all, say what you will, word of mouth is better than printers' ink.

And while you listened to the talk, you could be eating a stick of barber's-pole candy or a cent's worth of dates, or, if your wealth happened to admit of such extravagance, you could enjoy, after the Cranford fashion, quite unembarrassed by Cranford pudicity, a twocent orange. Those were the days of small things. Dollars did not grow on every bush. Seven-year-old boys, at all events, were not 
yet accustomed to go about jingling a pocketful of silver. Once, I remember, I saw a little chap sidle up to the counter and look long at the jack-knives and other temptations displayed in the showcase. By and by the shopkeeper espied a possible customer, and came round to see what was wanted.

"How much are those tops?" asked the boy, pointing with his finger.

"Ten cents," was the answer.

The boy was silent. He was thinking it over. Then he said : "I 'll take two cents' worth of peanuts."

Poor fellow! I have seen many a grown man since then who was obliged to content himself with the same kind of philosophy. And who shall say it is not a good one? If you cannot spend the summer in Europe, take a day at the seashore. If you miss of an election to Congress, bid for a place on the school committee. If you cannot write ten-thousand-dollar novels, write - well, write a weekly column in a newspaper. There is always something within a capable man's reach, though it be only "two cents' worth of peanuts." 


\section{BIRDS AT THE WINDOW}

The winter has continued birdless, not only in eastern Massachusetts, but, as far as I can learn, throughout New England. Letters from eastern Maine, the White Mountain region, and western Massachusetts all bring the same story : no birds except the commonest - chickadees and the like. Crossbills, redpolls, and pine grosbeaks have left us out in the cold.

The only break in the season's monotony with me has been a flock of six purple finches, seen on the 29th of January. I was nearing home, in a side street, thinking of nothing in particular, when I heard faint conversational notes close at hand, and stopping to look, saw first one and then another of the bright carmine birds; for five of the six were handsome adult males. All were eating savin berries, and conversing in their characteristic soft staccato. It was by all 


\section{THE CLERK OF THE WOODS}

odds the brightest patch of feathers of the new century. The birds must be wintering not far away, I suppose; but though I have been up and down that road a dozen times since February came in, I have seen nothing more of them. Within a month they will be singing, taking the winds of March with music. No more staccato then, but the smoothest of fluency.

Much the birdiest spot known to me just now is under our own windows - under them and against them, as shall presently be explained. Indeed, we may be said to be running a birds' boarding-house, and we are certainly doing an excellent business. "Meals at all hours," our signboard reads. We "set a good table," as the trade expression is, and our guests, who, being experienced travelers, know a good thing when they see it, have spread the news. There is no advertisement so effective as a satisfied customer.

The earliest comers are the blue jays. They anticipate the first call for breakfast, appearing before sunrise. Jays are a shrewd set. They can put two and two together with the sharpest of us. Man, they have dis- 
covered, is a laggard in the morning. Then is their time. In very bad weather, indeed, they come at all hours; but they are always wary. If I raise the window an inch or two and set it down with a slam, away they go; though, likely as not, I look out again five minutes later to find them still there. In times of dearth one may reasonably risk something for a good piece of suet.

The jays take what they can, somewhat against our will. The table is spread for smaller people: for downy woodpeckers, white-breasted nuthatches, and chickadees, with whom appears now and then, always welcome, a brown creeper. The table is set for them, I say; and they seem to know it. They come not as thieves, but as invited guests, or, better still, as members of the family. No opening and shutting of windows puts them to flight. Why should it? There are at least a dozen baiting-places about the house, and they know every one of them. Though the fare is everywhere the same, they seem to find a spice of variety in taking a bite at one table after another. 
My own principal enjoyment of the business, at present, is connected with a new toy, if I may call it so: a small, loosely knit, or crocheted, bag - made of knitting-cotton, I think I was told - sent to me by a correspondent in Vermont. Into this, following the donor's instructions, I bave put nutmeats and hung it out of a window of my workingroom, throwing a cord over the top of the upper sash, and allowing the bag to dangle against the pane.

At first I broke the nuts into small pieces, but I soon learned better than that. Now I divide the filbert once, and for the most part the birds (chickadees only, thus far) have to stay on the bag and eat, instead of pulling out the pieces whole and making off with them. The sight is a pretty one - as good as a play. I am careful not to fill the bag, and the feeder is compelled to hang bottom side up under it, and strike upward. The position is graceful and not in the least inconvenient, and possesses, moreover, a great economical advantage: the crumbs, some of which are of necessity spilled, drop on the eater's breast, instead of to the ground. I 
see him stop continually to pick them off. "Gather up the fragments," he says, "that nothing be lost."

When one of the pieces in the bag is so far nibbled away that a corner of it can be pulled through one of the interstices, matters become exciting. Then comes the tug of war. The eater, who knows that his time is limited, grows almost frantic. He braces himself and pulls, twitching upward and downward and sidewise ("Come out, there, will you?"), while the wind blows him to and fro across the pane, and one or two of his mates sit upon the nearest branch of the elm, eyeing him reproachfully. "You greedy thing!" they say. "Are you going to stay there forever?" Often their patience gives out (I do not wonder), and one after another they swoop down past the window, not to strike the offender, but to offer him a hint in the way of moral suasion. Sometimes one alights, with more or less difficulty, on the narrow middle sash just below, and talks to him; or one hovers near the bag, or even perches sidewise on the string, just above, as much as to say, "Look out!" Then I hear 
a burst of little, hurried, sweet-sounding, angry notes - always the same, or so nearly the same that my ear is unable to detect the difference.

Generally these manœurres are successful; but now and then the feeder is so persistently greedy that I am tempted to assert a landlord's prerogative and tell him to begone. Only once have I ever seen two birds clinging to the bag together, although so far as I can make out, there is nothing to hinder their doing so; and even then they were not eating, but waiting to see which should give place to the other.

All in all, it is a very pleasing show. It is good to see the innocent creatures so happy. Nobody could look at them, their black eyes shining, their black bills striking into the meats, all their motions so expressive of eager enjoyment, without feeling glad on their account. And with all the rest, it may be said that an ease-loving man, with a meddlesome New England conscience, is not always sorry to have a decent, or better than decent, excuse for dropping work once in a while to look out of the window. Who says we are 
idle while we are taking a lesson in natural history? I do not know how many times I have broken off (seeing a bird's shadow in the room, or hearing a tap on the pane) while writing these few paragraphs.

Once, indeed, I saw something like actual belligerency. Two birds reached the bag at the same instant, and neither was inclined to withdraw. They came together, bill to bill, each with a volley of those fine, spitfire notes of which I spoke just now, and in the course of the set-to, which was over almost before it began, one of them struck beak-first against the window, as if he were coming through. Then both flew to the elm branches, fifteen feet away, and in a moment more one of them came back and took a turn at feeding. I am not going to take in the bag for fear of the immoral effects of excessive competition. Competition - among customers - is the life of trade. I am glad to see my table so popular.

The nuthatches, of which we have at least two, male and female, as I know by the different color of their crowns, have not yet discovered the nuts, but come regularly to the 
suet in the trees, and pretty often to a piece that is nailed upon one of my window-sills. I hear the fellow's pleasant, contented, guttural, grunting notes, and rise to look at him, liking especially to watch the tidbits as they travel one after another between his long mandibles. Even if he does not call out, I know that it is he, and not a chickadee, by the louder noise he makes in driving his bill into the fat.

I have fancied, all winter, that the birds - these two nuthatches, I mean - were mated, seeing them so often together; and perhaps they are; but the other day I witnessed a littlc performance that seemed to put another complexion upon the case. I was leaving the yard when I heard bird notes, repeated again and again, which $I$ did not recognize. To the best of my recollection they were quite new. I looked up into a tree, and there were the two nuthatches, one chasing the other from branch to branch, with that peculiarly dainty, fluttering, mincing action of the wings, a sort of will-you-bemine motion, which birds are given to using in the excitement of courtship. There could 


\section{BIRDS AT THE WINDOW}

be no doubt of it, though it was only the 10th of February: Corydon was already "paying attentions" to Phyllis. Success to him! I notice, also, that chickadees are beginning to whistle "Phcbe" with considerable frequency, though there is nothing in the weather to encourage them. Birds have an almanac of their own. Spring is coming. 


\section{A GOOD-BY TO WINTER}

WINTER is not quite done, but it will be by the time this "Clerk" is printed. That is to say, $m y$ winter will be done. In this respect, as in many others, I am a conservative. My calendar is of the old school. "There are four seasons in the yearspring, summer, autumn or fall, and winter." So we began our school compositions; and by "spring" we meant the spring months - March, April, and May. The temperature might belie the almanac; there might be "six weeks' sledding in March;" but when March began, spring began.

And by the way, what a capital subject that was - "The Seasons"! A theme without beginning and without end; a theme to be taken seriously or humorously, in prose or verse; a theme of universal interest. Best of all, there was no difficulty about the first sentence. No need to sit for half an hour 
chewing the end of one's pencil and waiting for inspiration. Down it went: "There are four seasons in the year - spring, summer, autumn or fall, and winter." We never omitted to say "autumn or fall ;" the synonymy helped out the page, and gave us the more time in which to consider what we should say next. That is the great difficulty in authorship. On that shoal many a good ship has struck. A man who always has something to say next is bound to get on as a "space writer," if as nothing else.

Our opening remark was not strictly original, but we did not mind. It was true, if it wasn't new; and without being told, I think we had discovered - by intuition, I suppose - what older heads seem to have learned by rule, that it is good rhetoric, so to speak, to begin with a quotation. I was pleased, the other day, to see a brilliant essayist commending it as an excellent and becoming practice to leapfrog into one's subject over the back of some famous predecessor. Such was our custom, for better or worse, till a certain master ( $\mathrm{I}$ am tempted to name him, but forbear) announced just before the 
fatal day, that compositions on "The Seasons" would no longer be accepted. That was cruelty to authors. He spoke with a smile, but it was a smile of malice. I have never forgiven him. $\mathrm{He}$ is living still, a preacher of the gospel. When Saturday night comes, and he finds himself hard put to it for the morrow's sermon (as I have no doubt he often does - I hope so, at all events), does he never remember the day when with the word of his mouth he deprived thirty or forty young innocents of their easiest and best appreciated text? $\mathrm{He}$ is righteously punished. Let him preach to himself, some Sunday, from Numbers xxxii. 23 , "Be sure your sin will find you out."

Why should n't one write about the seasons, I wonder. There is scarcely anything more important, or more universally interesting, than the weather. Ten to one it was the first thing we all thought of this morning. And the seasons are nothing but weather in large packages - weather at wholesale. Their changes are our epochs, our date-points. But for them, all days being alike, there would be no calendar. It 
is well known that people who live in the tropics seldom know their own age. How should they, with nothing to distinguish one time of year from another? Young or old, they have never learned that " there are four seasons in the year."

We are better off. Life with us is not all in the present tense. As Hamlet said, we look before and after. (Hence it is, I suppose, that we have "such large discourse," and continue, some of us, to write compositions.) We live by expectation. "Behold," says the weather, "I make all things new." Every day is another one, and every season also. At this very minute a miraculous change is at hand. A great and effectual door is about to swing on its hinges, and I, for one, wish to be awake to see it; not to wake up by and by and find the door wide open.

So far from wearying of the seasons as an old story, I am more intensely interested in them than ever. If any of my fellow citizens are not just now thinking daily of the passing of winter and the advent of spring, I should like to know what they are made 


\section{THE CLERK OF THE WOODS}

of. For myself, I am like a man in jail. My term is about to expire, and I am notching off the days one by one on a stick. "Three more," say I; " two more." "Welcome the coming, speed the parting guest." And I am ready to hang my cap on the horns of the moon.

"You are too much in haste," some man will say; the same that said, "How are the dead raised up?" But I know better. It is one happy effect of ornithological habits that they shorten the winter. There will be no spring flowers for a good while yet, but there will be spring birds within a fortnight, perhaps within a week; nay, there may be some before night. Indeed, I have just come in from a two-hour jaunt, and at almost every step my ears were open for the first vernal note. I have seen bluebirds, before now, earlier than this; and what has happened once may happen again. So, while the wind blew softly from the southwest, and all the hills were mantled with a dreamy haze, I chose a course that would take me past one apple orchard after another; and, as I say, my ears (which I often think are 
better ornithologists than their owner, - if he is their owner) kept themselves wide awake. If that sweet voice, "Purity, purity" (with all bird lovers I thank Mr. Burroughs for the word) - if that heavenly voice, the gentlest of prophets, was on the breeze, they meant to hear it.

They heard nothing, but that is not to say that they listened to no purpose. They heard nothing, and they heard much; for there is an ear within the ear, and the new year's voice - which is the bluebird's - was in the deepest and truest sense already audible. The ornithologist failed to catch it ; for him Sialia sialis is still to look for; but the other man was in better luck.

The "new year's voice," I say; for the year begins with spring. We had the seasons in their true order when we were schoolchildren - "spring, summer, autumn or fall, and winter." It must have been some very old and prosy chronologist that arranged their progression as our almanacs now give it. The young are better instructed. Does not the Scripture say, "The last shall be first"? 
And within three days - I can hardly believe it - the old year will be done. So let it be. Its passing brings us so much nearer the grave; worse yet, perhaps, it leaves us with our winter's work half accomplished; but our eyes are forward. After all, our work is not important. We are twice too busy; living as our neighbors do, rather than according to the law of our own being; playing the fool (there is no fool like the busy one); selling our birthright for a mess of pottage. The great thing, especially in springtime, is to lie wide open to the life that enfolds us, while the "gentle deities" show us, for our delight, -

"The lore of colors and of sounds,

The innumerable tenements of beanty."

Yes, that is the wisdom we should pray for. The youngest of us will not see many springs. Let us see the most that we can of this one. So much there will be to look at! Now, of all times, we may say with one of old, " Lord, that I might receive my sight." What a new world we should find ourselves living in! I can hardly imagine it. 


\section{BIRD SONGS AND BIRD TALK}

I MENTIONED a fortnight ago a flock of half a dozen purple finches (linnets) seen and heard conversing softly among themselves in some roadside savin trees on the 29th of January. They must be passing the winter somewhere not far away, I ventured to guess. "Within a month," I added, "they will be singing, taking the winds of March with music."

This forenoon (March 5) I had walked up the same pleasant by-road, meaning to follow it for a mile or two, but finding myself insufficiently shod for so deep a slush, I turned back after going only a little way. It was too bad I should have been so improvident, I said to myself ; but accident is often better than the best-laid plan, and so it was now. As I neared the bunch of cedars - which I have looked into day after day as I have passed, hoping to find the lin- 
nets again there - I descried some smallish bird in one of the topmost branches of a tall old poplar across the field. My operaglass brought him nearer, but still not near enough, till presently he turned and took an attitude. "Ah, yes," said I; "a purple finch." Attitude and gait, though there may be nothing definable about them, are often almost as good as color and feature for purposes of identification. I had barely named the bird before he commenced singing, and as he moved into a slightly better light (the sky being clouded) I saw that he was a red one. He seemed to be not yet in full voice; perhaps he was not in full spirits; but he ran through with his long, rapid, intricate, sweetly modulated warble with perfect fluency, and very much to my pleasure. It was the first song of spring. The linnet is of the true way of thinking; spring, with him, begins with the turn of the month.

Purple finches, by the bye, are among the birds of which it has been said - by Minot, and perhaps by others - that both sexes sing. I hope the statement is true; I could never 
see any reason in the nature of things why female birds should not have musical susceptibilities and musical accomplishments; but I am constrained to doubt. It is most likely, I think, that the opinion has arisen from the fact that adult males - a year or more old, and fathers of families - sometimes continue to wear the gray, sparrow-like costume of the gentler sex.

My bird of this morning dropped from his perch while I was trying to get nearer to him, and could not be found again. I still suppose that the flock is spending the season somewhere not far off. I have lived with myself too long to imagine that birds must be absent because I fail to discover them.

Half an hour before, in almost the same place, I had stopped to look at six birds perched in a bare treetop. They were so silent, so motionless, and so closely bunched, that I put up my opera-glass expecting to find them cedar waxwings. Instead, they were nothing but blue jays. While my glass was still on them, the whole flock seemed to be taken with a dancing fit. This lasted for a quarter of a second, more or less, and was 


\section{THE CLERK OF THE WOODS}

so quickly over that I cannot say positively that it was anything more than an optical illusion. The next moment all hands took flight with loud screams. They did not go far, and presently crossed the road in front of me, still screaming lustily, for no reason that I could discover signs of. However, the blue jay is as far as possible from being a fool, and whenever he talks it is safe concluding that he has something to say.

It has long been an opinion of mine that the jay language is worthy of systematic study. Some man with a gift of patience and a genius for linguistics should undertake a jay dictionary; setting down not only all jay words and phrases, but giving us, as far as possible, their meaning and their English equivalents. It would make a sizable volume, and would be a real contribution to knowledge.

All bird language, I have no doubt, is full of significance. It has been evolved exactly as human language has been, and while it is presumably less copious and less nicely shaded than ours, it is probably less radically unlike it than we may have been accustomed 


\section{BIRD SONGS AND BIRD TALK 223}

to assume. That it has something answering to our " parts of speech " we may almost take for granted. It could scarcely be intelligible - as it assuredly is - if some words did not express action, others things, and still others quality. Verbs, substantives, adjectives, and adverbs, - these, at least, all real language must possess. The jay tongue has them, I would warrant, in rudimentary forms, but in good number and of clearly defined significance.

Jays are natural orators ; for among birds, as among men, there are "diversities of operations." "All species are not equally eloquent," said Gilbert White. And the same capable naturalist made another shrewd remark, which I would commend to the man, whoever he may be, who shall undertake the jay-English dictionary that I have been desiderating. "The language of birds," said White, "is very ancient, and, like other ancient modes of speech, very elliptical ; little is said, but much is meant and understood."

The blue jay, I am confident, though I do not profess to be a jay scholar, makes a large use of interjections. This will constitute one 
224 THE CLERK OF THE WOODS

of the difficulties with which his lexicographer will have to contend; for interjections, as all students of foreign tongues know, are among the hardest words to render from one language to another. A literal translation is liable to convey almost no meaning. When a Spaniard grows red in the face and vociferates, "Jesús, María y José!" he is not thinking of the holy family, but in all likelihood of something very, very different; and when a devout New England deacon hears some surprising piece of news, and responds with "My conscience!" he is not thinking at all of the voice of God in the soul of man. Such phrases - and the jay language, I feel sure, is full of them are not so much expressions of thought as vents for feeling. You may call them safetyvalves. Emotion is like steam. If you stop the nose of the tea-kettle, off goes the cover. The hotter the blood, of course, the more need for such exclamatory outlets; and the jay, unless his behavior belies him, is Spaniard, Italian, and Frenchman all in one. I pity his lexicographer if he undertakes to render all his subject's emotions in prim lit- 


\section{BIRD SONGS AND BIRD TALK 225}

erary English. But I hope he will do the best he can, and I promise to buy his book.

The linnet's was the first spring song, I said; but it was first by an inch only; for even while $I$ was setting down the paragraph a white-breasted nuthatch broke into a whistle close by my window. I turned at once to look at him. There he stood, in the top of the elm, perched crosswise upon a small twig, just as a sparrow might have been, and every half a minute throwing forward his head and emitting that peculiar whistle, broken into eight or ten syllables. Between times he looked to right and left, as if he had been calling for some one and was expecting a response. No response came, and after a little he disappeared.

That was the second spring song, and a good one, though not to be compared with the linnet's for musical quality. Now, say I, who bids for the third place? Perhaps it will be a bluebird, perhaps a robin, perhaps a song sparrow. 


\section{CHIPMUNKS, BLUEBIRDS, AND ROBINS}

THE season was opened, formally, on the 10th of March. I am speaking for myself. Friday, the 8th, brought genuine spring weather, sunny and warm, an ideal day for the first bluebird; but I was obliged to waste it in the city. The 9th was rainy and cold, and though I spent some hours out of doors, I saw no vernal signs. Birds of all sorts were never so few. The next morning - cloudy, with a raw northeasterly wind - I was fifteen minutes away from home when a squirrel came out of the woods on one side of the way and ran across the road before me. It was a chipmunk, my first one of the new year, wide-awake and quick on its legs; and it was hardly in the hazel bushes on the other side of the road before another joined it, and the two chased each other out of sight. Spring had come. 
Chickarees and gray squirrels have been common enough throughout the cold weather, but the chipmunk, or striped squirrel, takes to its burrow in the late autumn, and sleeps away the winter. In other words, along with the woodchuck (the largest and the smallest of our New England squirrels being alike in this respect), it migrates into the "land of Nod." I imagine, however, that its sleep is not so sound but that it wakes up now and then to feed, though as to this point I know really nothing, my impression arising wholly from the fact that chipmunks store away food. They would hardly do this, I should think, unless they expected to find a use for it.

Late in September, five months ago, I went to visit friends in the White Mountains, and one of the first things I heard from them was that Betty had disappeared. She had not been seen for about two months. Betty was a chipmunk that had been in the habit of coming upon the piazza, and had grown tame under kind treatment till she would take food from her friends' fingers and even climb into their laps. Once, in- 
deed, the lady of the house, having gone upstairs, noticed the presence of something heavy in her pocket (she is a naturalist, and for that reason, I suppose, still wears a pocket in her gown), and on putting her hand into it, found Betty inside.

But, as I say, Betty had suddenly discontinued her visits, and there was mourning at the cottage. Worse yet, there was wrath, and the stable cat had barely escaped with his life. But now, on a Sunday noon, when the cottagers appeared at the hotel dinnertable, they announced with beaming faces that there was great news: Betty had returned! I must come over and see her; for up to this time I knew her charms only by report.

As soon as dinner was finished, therefore, we repaired to the cottage veranda, and pretty soon, while we were talking of one thing and another, the lady said, " $\mathrm{Ah}$, here she is! Here's Betty!" Filberts had been provided, and she began at once to climb into our laps after them. She carried them away three at a time, - one in each cheekpouch and one between her teeth, - going 
and coming in the most industrious and businesslike manner. She would pass the winter in a state of hibernation, without a doubt, but her conduct obviously implied that she expected to see a time now and then when a bite of something to eat would " come handy."

My 10th of March chipmunks were a welcome sight. I wondered how long they had been awake. For several days, probably. And I tried to imagine what it must be like to open one's eyes after a five months' nap. Hibernation has the look of a miracle. And yet, what is it but a longer sleep? Well, perhaps sleep itself is a miracle - as truly so as life or thought. Probably, the world being all of a piece, if we understood one thing we should understand everything. Who knows? Anyhow, spring had come.

But there were no bluebirds. I kept on for two hours, past the likeliest of places, but saw and heard nothing. It was too bad, but there was no help for it. Bluebirds, blackbirds, song sparrows, fox sparrows, all were still to be looked for.

Then I sat indoors for an hour or two; 
I would stay in till afternoon, I thought; books, also, are a world, as Wordsworth said; but pretty soon the sun shone out; things looked too inviting. "I will go over as far as Longfellow's Pond," said I. "Perhaps there will be something in that quarter." That was a happy thought. I was hardly in the old cattle pasture, feeling it good to have the grass under my feet once more, all bleached and sodden though it was, when I stopped. Was n't that a bluebird's note? No, it was probably nothing but my imagination. But the sound reached me again; faint, fugacious, just grazing the ear. I put up my hands to my ears' help, and stood still. Yes, I certainly heard it; and this time I got its direction. A glance that way and I saw the bird, pretty far off, at the tip of an elm sapling standing by itself down in a sheltered hollow. I leveled my field-glass upon him (it was well I had brought it), made sure of his color, a piece of pure loveliness, and hastened to get nearer. Before I could turn the corner of the intervening wire fence, however, he took flight, and another with him. I followed hastily, and was approach- 
CHIPMUNKS, BLUEBIRDS, ROBINS 231

ing some roadside maples when the voice was heard anew, and the two birds, both calling, mounted into the air and vanished beyond the wood northward.

What a sweet voice the bluebird's is ! Calling or singing, it is the very soul of music. And the spring was really open. I went home in high spirits.

This happened on the 10th. Now it is the 13th. I have seen no more bluebirds, and song sparrows are still missing; but this morning an ecstatic purple finch warbled, and better still (for somehow, I do not know how or why, it gave me more pleasure), a flicker called again and again in his loud, peremptory, long-winded manner. $\mathrm{He}$, or another like him, has been in the neighborhood all winter, but this was his first spring utterance. It was no uncertain sound.

The bluebird peeps in upon us, as it were. His air is timid. "Is winter really gone?" he seems to say; but the flicker is a breezier customer. His mood is positive. He pushes the door wide open, and slams it back against the wall. "Spring, spring!" he shouts, and 
all the world may hear him. Soon he and the downy will begin their amorous drumming on dry stubs and flakes of resonant bark.

This was early in the morning. Since then I have been over to the cattle pasture, and in it found a flock of ten or twelve robins. They were feeding in the grass, but at my approach flew into some savin trees and fell to eating berries. As seems to be always true at this time of the year, they were in splendid color, and apparently in the very pink of physical condition; their bills were never so golden, it seemed to me, nor their heads so velvety black, nor their eyelids so white. They would not sing, but it was like the best of music to hear them cackle softly as they flew from the grass into the cedars. Say what you will, the robin is a pretty fine bird, especially in March. 


\section{MARCH SWALLOWS}

THE birds are having their innings. They have been away and have come back, and even the most stolid citizen is for the moment aware of their presence. I rejoice to see them so popular.

Two or three mornings ago I met a friend in the road, a farmer, one of the happy men, good to talk with, who glory in their work. A phobe was calling from the top of an elm, and as we were near the farmer's house I asked, "How long has the phœbe been here?" He looked up, saw the bird, and answered with a smile, " $\mathrm{He}$ must have just come. I have n't heard him before." I made some remark about its being pleasant to have such creatures with us again, and he responded, as I knew he would, in the heartiest manner. "Oh, I do love to see them!" he said.

I was reminded of a lady of whom I had 
234 THE CLERK OF THE WOODS

been told the day before. She had felt obliged, as I heard the story, to attend a meeting of the woman's club, but remarked to one of her assembled sisters that she had had half a mind to stay at home. The truth was, she explained, that two or three meadow larks were singing gloriously in the rear of her house, and she could hardly bear to come away and leave them. I hope her self-denial was rewarded.

On the same day I heard of a servant who hastened into the sitting-room to say to her mistress, "Oh, Mrs. — ! there 's a little bird out in the hedge singing to beat the band." The newcomer proved to be a song sparrow, and the lady of the house was fully as enthusiastic as the servant in her welcome of it, though I dare say she expressed herself in less picturesque language.

And I know another house, still nearer home, where a few days ago the dinner-table was actually deserted for a time, in the very midst of the meal. Three bluebirds, with snowbirds, goldfinches, and chickadees, had suddenly appeared under the windows. "There! there! In the maple! Will you 
look at him! Oh-h-h!" The dinner might "get cold," as the prudent housewife suggested, but it did not matter. Such a color as those bluebirds displayed was better than anything that an eater could put into his mouth.

Yes, as I say, the birds are having their innings. In whichever direction I walk, in town or country, I am asked about them. A schoolgirl stopped me in the street the other day. "Can you tell me what that bird is?" she inquired. A white-breasted nuthatch was whistling over our heads in a shade tree. Possibly the study of live birds will be as fashionable a few years hence as the wearing of dead ones was a few years ago.

On the 22d of March, as I stood listening to a most uncommonly brilliant song sparrow (now is the time for such things, before the greater artists monopolize our attention) and the outgivings of a too chary fox sparrow, the first cowbird of the year announced himself. Polygamist, shirk, and, by all our human standards, general reprobate, I was still glad to hear him. He is what he was made. Few birds are more interesting, psychologically, if one wishes an object of study. 
Saturday, the 23d, was cloudless, a rare event at this time of the year, and with an outdoor neighbor I made an excursion to Wayland, to see what might be visible and audible in those broad Sudbury River meadows.

We took a "round" familiar to us (to one of us, at least), down the road to the north bridge and causeway, thence through the woods on the opposite side of the river to a main thoroughfare, or turnpike, and back to the village again over the south causeway. Meadow larks were in full tune, now from a treetop, now from a fence-post. They were my first ones since the autumn, and their music was relished accordingly.

As we stopped on the bridge to look down the blue river and across the overflowed meadow lands to a gray, flat-topped hill far beyond toward Concord, we suddenly discovered a shining white object on the surface of the water. It proved to be a duck, one of two, jet black and snow white, and presumably a merganser, though it was too far away to be made out with positiveness. Thoreau, I remember, makes frequent mention of 
mergansers and golden-eyes in his March journals.

We were admiring this couple (a couple only in the looser sense of the word, for both birds were drakes), when all at once some small far-away object "swam into my ken." "A swallow!" said I, and even as I spoke a second one came into the field of the glass. Yes, there they were, two white-breasted swallows, sailing about over the meadows on the $23 \mathrm{~d}$ of March. How unspeakably beautiful they looked, their lustrous blue-green backs with the bright sun shining on them ! The date must constitute a "record," I assured my companion. Once before, at least, I had seen swallows in March, but that, I felt certain, was on one of the last days of the month. Strange that such creatures should have ventured so far northward thus early. If Gilbert White could see them, he would be more firmly convinced than ever that swallows "lay themselves up in holes and caverns, and do, insect-like and bat-like, come forth at mild times, and then retire again to their latebræ." For my own part, not being able to accept this doctrine, I con- 
tented myself with Americanizing Shakespeare. "Swallows," said I, -

"Swallows that come before the daffodil dares, And take the winds of March with beauty."

I could hardly recover from my excitement, which was renewed an hour afterward when, on the southern causeway, a third bird (or one of the same two) passed near us. But now see how untrustworthy a clerk a man's memory is! On reaching home I turned at once to my book of dates, and behold, it was exactly four years ago to an hour, March 23, 1897, that I saw two whitebreasted swallows about a pond here in Wellesley. We had broken no "record," after all. But I imagine the Rev. Gilbert White saying, "Yes, yes ; you will notice that in both cases the birds were seen in the immediate neighborhood of water." And there is no doubt that such places are the ones in which to look most hopefully for the first swallows of the year.

All this time a herring gull, a great beauty in high plumage, was sailing up and down the meadows like a larger swallow. $\mathrm{He}$; too, was one of Thoreau's river friends 
at this season; and since we are talking of dates, I note it as a coincidence that precisely forty-two years ago (March 23, 1859), he entered in his journal that he saw "come slowly flying from the southwest a great gull, of voracious form, which at length, by a sudden and steep descent, alighted in Fair Haven Pond [a wide place in the river], scaring up a crow which was seeking its food on the edge of the ice." Our bird, also, made one "sudden and steep descent," and picked from the ice some small, darkcolored object, which at our distance might have been a dead leaf. But if Thoreau saw ducks and gulls, he saw no March swallows. His earliest date for them, so far as the printed journals show, seems to have been April 5.

The woods brought us nothing, — beyond a chickadee or two, — but we were hardly out of them before we heard the blue-jay scream of a red-shouldered hawk, and presently saw first one bird and then another (rusty shoulder and all) sailing above us. A grand sight it is, a soaring and diving hawk. May it never become less frequent. 
I must quote Thoreau once more, this time from memory, and for substance only. I am with him, heart and soul, when he prays for more hawks, though at the cost of fewer chickens. And I like the spirit of a friend of mine who girdled a tall pine tree in his woods, that it might serve as a perching station for such visitors.

As we approached the village again, we came upon two phœbes. Like the whitebreasted swallow, the phœbe winters in Florida, and is by a long time the earliest member of its family to arrive in New England. Red-winged blackbirds were numerous, of course, every one a male, and in one place we passed a flock of crow blackbirds feeding on the ground.

Not the least interesting bird of the forenoon was a shrike, sitting motionless and dumb in an apple tree. The shrike has all the attractiveness of singularity. $\mathrm{He}$ is no lover of his kind, save as the lion loves the lamb and the hawk the chicken. Lonesome? No, I thank you. Except in breeding-time, he is sufficient unto himself. Even when he happens to feel like conversation, he goes 
not in search of company. He is like the amiable philosopher who was asked by some busybody why he so often talked to himself. "Well," said he, "for two reasons : first, I like to talk to a sensible man, and secondly, I like to hear a sensible man talk." In the present instance the shrike may very well have considered that there was little occasion for his talking, either to himself or to anybody else, since a bunch of twenty masculine redwings in some willow trees near by were chattering in chorus until, to use a good Old Colony phrase, a man could hardly hear himself think. Blackbird loquacity, each particular bird sputtering " to beat the band," is one of the wonders of the world. 


\section{WOODCOCK VESPERS}

When I came to this town to live, in April, ten years ago, one of my first concerns was to find a woodcock resort. The friend with whom I commonly took a stroll at sundown had never heard the "evening hymn" of that bird, and, knowing him for a lover of " the poetry of earth," I was eager to help him to a new pleasure. If the thing was to be done at all, it must be done soon, as the bird's musical season is brief. So we walked and made inquiries.

A farmer, who knew the region well, told us that woodcock used to be common about a certain swamp, but had not been so, he thought, of recent years. We visited it, of course, but heard nothing. Then the same man bethought himself of a likelier place, farther away. Thither, also, we went, having to hasten our steps, for the bird must be caught at precisely such a minute, between 
daylight and dark. Still we had our labor for our pains. And so the season passed, with nothing done.

Then, a year or two afterward, walking one afternoon in a quiet back road, I startled a woodcock from directly beside the track. "W Well, well," said I, "here is the very place;" for I noticed not far off a bit of alder swamp, with a wood behind it and an open field near by. All the conditions were right, and on the first available evening, with something like assurance, I made my way thither. Yes, the bird was there, in the full ecstasy of his wonderful performance — for wonderful it surely is.

My friend was not with me, however, and for one reason or another, now past recall, another year went by without our being able to visit the spot together at the necessary minute. Then a day came. He heard the bird (well I remember the hour), was delighted beyond measure, and that very evening, still under the spell of the "miracle," put his impressions of it on paper. The next day they were printed, and I remember still my pleasure when the most competent 
of all men to speak of such a matter sent me word that it was the best description of the performance that he had ever seen. If any of my readers desire to see it, it is to be found in a little volume of most delightful outdoor essays entitled "The Listener in the Country."

All this I lived over again last evening as I went, alone, to the same spot - not having visited it on this errand for several years to see whether the bird would still be true to his old tryst. I believed that he would be, in spite of the skepticism of a wide-awake man who lives almost within stone's throw of the place; for though woodcock are said to be growing less and less common, I have strong faith in the conservative disposition of all such creatures. Once they have a place to their mind, they are likely to hold it.

Fox sparrows were singing in their best manner as I passed on my way, and I would gladly have stayed to listen; their season, also, is a short one; but I kept to my point.

And after all, I arrived a few minutes ahead of time. Up and down the road I paced (no one in sight, nor any danger of 
any one), with an ear always awake for a certain note, the "bleat," so called, of the woodcock. Should I hear it? It was fast getting dark, the western sky covered with black clonds (a great disadvantage), with only scattered gleams of bright color, very narrow, just on the horizon. Hark! Yes; that was it-Spneak. There is no putting the sound into letters, but those who know the call of the nighthawk may understand sufficiently well what I am trying to express, for the two notes are almost identical.

With this note, single, repeated for a considerable time at intervals of perhaps half a minute, - the bird still on the ground, and turning about, so that some of his utterances sound three or four times as far away as others, - with this strange, unmusical, almost ridiculous overture the woodcock invariably introduces his evening recital. I wait, therefore, leaning against the heavy stone wall, costly and unromantic, with which the rich new owner of the land has lately fenced his possession, till all at once the silence is broken by the familiar whistling noises made by the heavy bird as he leaves the ground. This 
time they are unusually faint, and are lost almost immediately. Only for my acquaintance with the matter I should assume that the bird had flown away, and that my evening was lost. As it is, I continue to listen. Once and again I catch the sounds. The fellow is still rising. I can see him, but only in my mind's eye. Those black clouds hide him quite as effectually as if he were behind them. Still I can see him. I know he has gone up in a broad spiral - up, up, up, as on a winding staircase.

Now, after silence, begins a different sound, more musical, more clearly vocal; breathless, broken, eager, passionate, ecstatic. And now, far aloft in the sky, where the clouds are of a lighter color, I suddenly catch sight of the bird, a dark speck, shooting this way and that, descending in sharp zigzags, whistling with his last gasps. And now, as if exhausted, - and well he may be,-he drops to earth (I see him come down) very near me, much nearer than I had thought.

Spneak, he calls. I know exactly what is coming. At intervals, just as before, he repeats the sound, till suddenly he is on the 
wing again, whistling as he goes. He flies straight from me, - for this time, by good luck, I see him as he starts, - and mounts and mounts. Then, far, far up, he whistles, zip, zip, and then, when he can stay no longer, comes down in crazy zigzags.

A wonderful display. If a man could be as truly enraptured as the woodcock seems to be, he would know the joys of the blest. I wonder how many thousand Aprils this cumbrous-looking, gross-looking, unpoeticallooking bird has been disporting himself thus at heaven's gate. There must be a real soul in a creature, no matter what his appearance, who is capable of such transports and ravishments, such marvelous upliftings, such mad reaches after the infinite.

I listen and wonder, and then come away, meditating on what I have seen and heard. The last of the small birds have fallen silent. Only a few hylas are peeping as I pass a cranberry meadow. Then, halfway home, as the road traverses a piece of woods, with a brook singing on one side, and the moon peeping through fleecy clouds, suddenly I halt. That was a screech owl's 
voice, was it not? Yes ; faint, tremulous, sweet, a mere breath, the falling, quavering strain again reaches my ear. The bird is somewhere beyond the brook. I wonder how far. Well up on the wooded hillside, I think it likely. I put my hands behind my ears and hearken. Again and again I hear it; true music! music and poetry in one; the voice of the night. But look! What is that dark object just before me on a low branch not two rods away? There is no light with which to be sure of its outlines; a tuft of dead leaves, perhaps ; but it is of a screech owl's size. Another phrase. Yes, it comes from that spot, or I am tricked. And now the bird moves, and the next instant takes wing. But he goes only a few feet, and alights even nearer to me than before. How soft his voice is! Almost as soft as his flight. How different from the woodcock's panting, breathless whistle! Though I can see him, and could almost touch him, the tremulous measure might still be coming from the depths of the wood. I listen with all my ears, till an approaching carriage turns a corner in the road below. 


\section{WOODCOCK VESPERS}

I hope the owl will not mind; but as the wheels come near he leaves his perch, flies directly before my face (with no more noise than if a feather were falling through the air), and disappears in the forest opposite.

Two good birds I have listened to. The evening has been kind to me. Two birds? nay, two poets : a poet in a frenzy, and a poet dreaming. 


\section{UNDER APRIL CLOUDS}

\section{"Good-Morning."}

"Ah, good-morning. How are you?"

I was on what I suppose is habitually the most crowded sidewalk in Boston, where men in haste are always to be seen betaking themselves to the street as the only means of making headway. A hand was laid on my shoulder. A business man, one of the busiest, I should think he must be, had come up behind me. He was looking happy. Yes, he said, he was very well. " And yesterday," he continued, "I had a great pleasure. I saw my first fox-colored sparrow, and heard him sing."

No wonder his face shone. His condition was enviable. The fox sparrow is a noble bird, with a most musical voice, the prince of all sparrows. To hear him for the first time - if one does hear him - is a real event. A man might well walk a crowded 
city sidewalk the next day and smile to himself at the memory of such high fortune.

After all, happiness is a good thing. Not so desirable, perhaps, as a great office, or a mint of money, but a pretty good thing, nevertheless. It is encouraging, in these days of far-sought pleasures and prodigal expense, to see men get it at a low rate and on innocent terms.

For myself, I think I have never known fox sparrows more plentiful than for the past week. From our human point of view their present migration has been eminently favorable; from the birds' point of view it has probably been in the highest degree unfavorable, the prolonged spell of cloudy and rainy weather having made night flights difficult, not to say impossible. The travelers have been obliged to stay where the storm had caught them, and we, at this intermediate station, have profited by their misfortune.

On the 7 th $I$ stood in the midst of as fine a flock as a man could wish to see. A thick cloud enveloped us; we might have been on a mountain-top; but for the minute it had ceased raining, and the birds were in a lively 


\section{THE CLERK OF THE WOODS}

mood. Sometimes as many as five or six were singing together, while a chorus of snowbirds trilled the prettiest of accompaniments; a concert worthy of Easter or any other festival.

The weather has been of a kind to keep night-traveling migrants here, I say; which is as much as to say that it has been of a sort to prevent other such birds from arriving. There have been no bright nights, I think, since April came in. So it happens, according to my theory (which may be as sound or as unsound as the reader pleases), that although it is now the 10th of the month, there has been, for my eye, no sign of chipper, field sparrow, or vesper sparrow. How should there be? How should such creatures find their way, with the fog and the rain blinding them night after night? No doubt they are impatient to be at home again in the old dooryards, the old savin-dotted pastures, and the old hay-fields. By and by the clouds will vanish, and they will hasten northward in crowds. The night air will be full of them, and the next day all outdoor, bird-loving people will be in clover. 
Unfavorable as the weather is, however, and against all probabilities, one cannot quite forego seasonable expectations. I pass the border of a grass field. A sparrow sings in the distance, and I stop to listen. Could that have been a vesper sparrow? The song comes again. No ; it begins a little in the vesper's manner; the opening measure is unusually smooth and unemphatic; but the bird is only a song sparrow. It is no shrewder than Peter. Its speech bewrayeth it.

One kingfisher I have seen, shooting through the misty air far aloft, his long wings making him look at that height like some seabird or wader. I remember when the sight — not uncommon in spring - was to me an insoluble mystery. As for calling the bird a kingfisher, such a thought never occurred to me. I knew the kingfisher well enough, or imagined that I did, but not at that altitude and flying in that strong, purposeful manner. Yet even at such times he commonly sounds his rattle before him, as if he wished his identity and his whereabouts to be known. 


\section{THE CLERK OF THE WOODS}

I have seen also a single marsh hawk. That was on the 9 th, and the circumstances of the case were ludicrous. I had stopped to look down from a wooded hilltop into a swampy pool, where ducks sometimes alight, when I saw a white object moving rapidly along the farther side of the swamp, now visible, now hidden behind a veil of trees and shrubbery. A road runs along that border of the swamp, and I took this moving white object for a bundle which a boy was carrying upon a bicycle (making pretty quick time), till suddenly I perceived that it was only a marsh hawk's rump! A redwing had given chase to the hawk - mostly for sport, I imagine, or just to keep his hand in; for I do not suppose he could have had any real grudge to settle. Probably this is the first case on record in which a hawk was ever mistaken for a wheelman.

Two evenings ago I made a solitary excursion to an extensive swamp and meadow, hoping to witness, or at least to hear, the aerial performance of the snipe. The air was full of a Scotch mist, and the sky cloudy. If the birds were there, and in a performing 
mood, they would be likely to get under way in good season. I waded across the meadow out of the sight of houses, and, having found what seemed to be a promising position, I took it and held it for perhaps an hour. But I heard none of those strange, ghostly, swishing noises that I was listening for. Perhaps the birds had not yet arrived. Perhaps this was not a snipe meadow.

For a time robins and song sparrows made music more or less remote, and an unseen fox sparrow, nearer at hand, amused me with excellent imitations of the brown thrasher's smacking kiss. Then, as it grew really dark, I relinquished the hunt and started homeward. And then the real music began; for as I approached the highway I heard the whistle of a woodcock, and presently discovered that, for the first time in my life, I was walking through what might be called a veritable woodcock concert. Once three birds were vocal together; one was "bleating" on the right, another on the left, while a third was at the very height of his ecstasy overhead. For a mile or more I walked under a shower of this incomparable, 
indescribable music. It dropped into my ears like rain from heaven.

One bird was calling just over the roadside wall. I stole nearer and nearer, taking a few cautious steps after each bleat, till finally I could hear the water dropping into the hogshead. I wonder how many readers will know what I mean by that. After each call, as a kind of pendant to it, there comes, if you are very, very close, a curious small sound, exactly as if a drop of water (the comparison is not mine) had fallen into a hogshead already half full. I had not heard it for years. In fact, I had forgotten it, and heard it now for the first few times without recollecting what it was.

Then the bird rose - always invisible, of course, for by this time there was no thought of seeing anything - and went skyward in broad circles, till he was at the top of his flight, and when he descended he came to earth on the other side of the road, a good distance away. He had seen me, I suppose, with those big bull's-eyes of his, which do so much to heighten the oddity of his personal appearance. 
He was the last of his kind. For the rest of my walk I heard no music except the sweet whistling of hylas here and there, and once, in a woodland pool, the grating chorus of a set of wood frogs.

Butterflies are waiting for sunshinelike the rest of us; I have not seen so much as an Antiopa; and the only wild flowers I have yet picked are the pretty red blossoms (pistillate blossoms) of the hazel; tiny things, floral egrets, if you please to call them so, of a lively and beautiful color. Sunshine or no sunshine, they were in bloom for Easter. 


\section{FLYING SQUIRRELS AND SPADE- FOOT FROGS}

IT is pleasant to realize familiar truths anew; to have it brought freshly to mind, for example, how many forms of animal life there are about us of which we seldom get so much as a glimpse.

In all my tramping over eastern Massachusetts I have met with two foxes. One I saw for perhaps the tenth part of a second, the other for perhaps two or three seconds. And probably my experience has not been exceptional. In this one particular it would be safe to wager that not one in ten of those who read this article will be able to boast of any great advantage over the man who wrote it. Yet every raiser of poultry hereabout will certify that foxes are by no means uncommon, and I know a man living within fifteen miles of the State House who, last winter, by a kind of "still hunt" - without 
a dog - killed three foxes in as many successive days. Reynard has fine gifts of invisibility, but a man with foxes on his mind will be likely to find them.

This same near neighbor of mine takes now and then an otter; only three or four weeks ago he showed me the skin of one on its stretching-board; and the otter is an animal that $I$ not only have never seen in this part of the world, but never expect to see. I have n't that kind of an eye. As for muskrats, the trapper takes them almost without number; " rats," he calls them ; while to me it is something like an event if once or twice a year I happen to come upon one swimming in a brook.

Another of these seclusive races, that manage to live close about us unespied by all except the most inquisitive of their human neighbors, is the race of flying squirrels. Whether they are more or less common than red squirrels, gray squirrels, and chipmunks, it would be difficult to say; but while red squirrels, gray squirrels, and chipmunks flit before you wherever you go, you may haunt the woods from year's end to year's end with- 
out seeing hide or hair of their interesting cousin. Flying squirrels stir abroad after dark; not because their deeds are evil (though they are said to like small birds and birds' eggs), but because - well, as the wise old nursery saw very conclusively puts it, because " it is their nature to."

Several times during the past winter I made attempts to see them (the story of one of these attempts has been told in a previous chapter), but always without success, though twice I was taken to a nest that was known to be in use. The other day I went to the same place again, the friend who conducted me having found a squirrel there that very forenoon. He shook the tree, a small gray birch, with a nest of leaves and twigs perched in its top, and out peeped the squirrel. "See him?" said my friend. "Yes." Then he gave the tree a harder shake, and in a moment the creature spread his "wings" and sailed gracefully away, landing on the trunk of an oak not far off, at about the height of my head. There he clung, his large handsome eye, full of a startled emotion, fastened upon me. I wondered if he would 
let me put my hand on him; but as I approached within three or four yards he scrambled up the tree into the small branches at the top. He was going to take another flight, if the emergency seemed to call for it, and the higher he could get, the better. The oak was too big to be shaken, but a smaller tree stood near it. This my companion shook in the squirrel's face, and again he took flight. This time he passed squarely over my head, showing a flat outspread surface sailing through the air, looking not the least in the world like a squirrel or any other quadruped. Again he struck against a trunk, and again he ran up into the treetop. And again he was shaken off.

Four times he flew, and then I protested that I had seen enough and would not have him molested further. We left him in a maple-top, surrounded by handsome red flower clusters.

The flight, even under such unnatural conditions, is a really pretty performance, the surprising thing about it being the ease and grace with which the acrobat manages to take an upward turn toward the end of his 
course, so as always to alight head uppermost against the bole.

It would be fun to see such a carnival as Audubon describes, when two hundred or more of the squirrels were at play in the evening, near Philadelphia, running up the trees and sailing away, like boys at the old game of "swinging off birches." "Scores of them," he says, "would leave each tree at the same moment, and cross each other, gliding like spirits through the air, seeming to have no other object in view than to indulge a playful propensity."

Compared with that, mine was a small show; but it was so much better than nothing.

Two mornings later (April 30) I was walking up the main street of our village, lounging along, waiting for an electric car to overtake me, when I heard loud batrachian voices from a field on my left hand. "Aha!" said I, "the spade-foots are out again." It had occurred to me within a day or two that this should be their season, if, as is believed, their appearance above ground is conditioned upon an unusual rainfall. 
Some years ago, when I was amusing myself for a little with the study of toads and frogs, checking Dr. J. A. Allen's annotated list of the Massachusetts batrachia, I became very curious about this peculiar and little understood species, known scientifically as Scaphiopus holbrookii, or the solitary spadefoot. It was originally described from South Carolina, I read, and was first found in Massachusetts, near Salem, about 1810. Its cries were said to have been heard at a distance of half a mile, and were mistaken for those of young crows. For more than thirty years afterward the frogs were noticed at this place only three times. They were described as burrowing in the ground, coming forth only to spawn, and that, as far as could be ascertained, at very irregular intervals, sometimes many years in length.

This, as I say, I read in Dr. Allen's catalogue, to the great sharpening of my curiosity. If I ever heard such noises, I should be prepared to guess at the author of them. Well, some years afterward (it was almost exactly eight years ago), fresh from a first visit to Florida, where my ears had grown 


\section{THE CLERK OF THE WOODS}

expectant of strange sounds (a great use of travel), I stepped out of my door one evening in late April, and was hardly in the street before I heard somewhere ahead of me a chorus of stentorian frog-notes. "That should be the spade-foot's voice," I said to myself, with full conviction. I hastened forward, traced the tumult to a transient pool in a field, and as I neared the place picked up a board that lay in the grass, and with it, by good fortune, turned the first frog I came in sight of into a specimen. This I sent to the batrachian specialist at Cambridge, who answered me, as I knew he would, that it was Scaphiopus.

My spade-foots of yesterday morning were in the same spot. I could not stay then to look at them, for at that moment the car came along. I left it at a favorite place in the next township, and had gone a mile or so on foot when from another transient roadside pool I heard the spade-foot's voice again. This was most interesting. I skirted the water, trying to get within reach of one of the performers. The attempt was unsuccessful; but in the course of it I saw 
for the first time the creature in the act of calling. And every time I saw him I laughed. He lay stretched out at full length upon the surface of the pool, floating high, as if he were somehow peculiarly buoyant. Then suddenly his hind parts dropped, his head flew up, his enormous white, or pinkishwhite, vocal sac was instantaneously inflated (like a white ball on the water), and the grating call was given out; after which the creature's head dropped, his hinder parts bobbed up into place (sometimes he was nearly overset by the violence of the action), and again he lay silent.

This same ludicrous performance - which by the watch was repeated every three or four seconds - I observed more at length in the other pool after my return. It seems to be indulged in only so long as the frogs are unmated. I took it for the call of the male, the "lusty bachelor." At the same moment couples lay here and there upon the water, all silent as dead men.

That was yesterday afternoon. At night, as had been true the evening previous (the neighbors in at least four of the nearer 
houses having noticed the uproar), the chorus was loud. I could hear it from my window, perhaps a quarter of a mile distant. This morning there is no sign of batrachian life about the place. Within a very short time - long before the tadpoles, which will be hatched in two or three days, can possibly have matured - the pool will in the ordinary course of nature have dried up, and all those eggs will have gone to waste.

A strange life it seems. What do the frogs live on underground? Why do they omit, year after year, to come forth and lay their eggs? Do they wait to be drowned out, and then (like thrifty farmers, who improve a wet season in which to marry) proceed to perpetuate the species?

These and many other questions it would be easy to ask. Especially one would like to read from the inside the story of the life and adventures of the young, which grow from the egg to maturity - through tadpole to frog - without seeing father or mother. What a little we know! And how few are the things we see! 


\section{THE WARBLERS ARE COMING}

TheY are a grand army. The Campbells are nowhere in the comparison, whether for numbers or looks. And this is their month. Let us all go out to see them and cry them welcome.

They are late, most exceptionally so. I have never known anything to match it. Brave travelers as they are (some of them, yes, many of them, are on a three or four thousand mile journey; and a long flight it is for a five-inch bird, from South America to the arctic circle) - brave travelers as they are, they cannot contend against the inevitable, and our April weather, this year, was too much even for a bird's punctuality.

The yellow warbler, for example, one of the prettiest of the tribe, is by habit one of the truest to his schedule. In any ordinary season he may be confidently expected to arrive in our Boston country on the first 


\section{THE CLERK OF THE WOODS}

day of May. If conditions favor his passage, he may even anticipate the date, perhaps by forty-eight hours. This year not a yellow warbler was to be seen up to May 6 . Then, between the evening of the 6 th and the morning of the $7 \mathrm{th}$, the birds dropped into their accustomed places, and in the early forenoon, when I went out to look for them, they were singing as cheerily as if they had never been away. With nothing but their wits and their wings to depend upon, I thought they had done exceedingly well. To me, on such terms, South America would seem a very long way off.

The same night brought the Nashville warblers. On the 6 th not one was visible, for I made it my business to look. On the morning of the $7 \mathrm{th} I$ had no need to search for them. In all the old haunts, among the pitch-pines and the gray birches, they were flitting about and singing, as fresh as larks and as lively as crickets. They, too, have come from the tropics, and will go as far north, some of them, as "Labrador and the fur countries." A bold spirit may live under a few feathers. 
THE WARBLERS ARE COMING 269

With them, I am pretty sure, came a goodly detachment of myrtle warblers (yellow-rumps), though the advance guards of that host (two birds were all that fell under my eye) were seen on the 18th of April. The great host is still to come; for the myrtles are a host, - a multitude that no man can number. As I listen to their soft, dreamy trill on these fair spring mornings, when the tall valley willows are all in their earliest green, - a sight worth living for, I seem sometimes to be for the moment on the heights of the White Mountains. Well I remember how much I enjoyed their quiet breath of song on the snowy upper slopes of Mt. Moosilauke in May a year ago. For the myrtle, notwithstanding his name, is a great lover of knee-high spruces.

$\mathrm{He}$ is a lovely bird, wherever he lives, and it is good to see him flourish, though by so doing he forfeits the peculiar charm of novelty. Everything considered, I am bound to say, that is not so regrettable a loss. If he were as scarce as some of his relatives, every collector's hand would be against him. Czars and rare birds must pay the price. 
The first member of the family to make his appearance with me this spring was the pine warbler. He was trilling in a pine grove (his name is one of the few that fit) on April 17. "The warblers are coming," he said. Not so pronounced a beauty as many of his tribe, he is one of the most welcome. He braves the season, and with his lack of distinguishing marks and his preference for pine-tops, he offers an instructive deal of puzzlement to beginners in ornithology. His song is simplicity itself, and, rightly or wrongly, always impresses me as the coolest of the cool.

I stood the other day between a pine warbler and a thrasher. The thrasher sang like one possessed. He might have been crazy, beside himself with passion. Operatic composers, aiming at something new and brilliant in the way of a "mad scene," should borrow a leaf out of the planting bird's repertory. The house would "come down," I could warrant. The pine warbler sang as one hums a tune at his work. Among birds, as among humans, it takes all kinds to make a world. 
After the advent of the myrtle warblers, on April 18, eleven days elapsed with no new arrivals, so far as I discovered, except a few chipping sparrows, first seen on the 23d! The weather was doing its worst. Then, on the 29th, I saw three yellow palm warblers. They were singing, as they usually are at this season - singing and wagging their tails, and incidentally putting me in mind of Florida, where in winter they are seen of every one. It is noticeable that these three earliest of the warblers all have, by way of song, a brief trill. Very much alike the three efforts are, yet clearly enough distinguished, if one hears them often enough. The best and least of them is the myrtle's, I being judge.

The yellow palm warbler ought to be a Southerner of the Southerners, one would say, from his tropical appellation; but the truth is that he makes his home from Nova Scotia northward, and visits the land of palms only in the cold season. $\mathrm{He}$ is a low-keeping bird (for a warbler), much on the ground, very bright in color, and well marked by a red crown, from which he is 
often called the yellow redpoll. If he could only keep his tail still!

Next in order was the black-throated green (May 4), which, take him for all in all, is perhaps my favorite of the whole family. $\mathrm{He}$ is the bird of the white pine, as the pine warbler is the bird of the pitchpine. And now we have a real song; no longer a simple trill, but a highly characteristic; sweetly modulated tune - or two tunes, rather, perfectly distinguished one from the other, and equally charming. If the voice is rough, it is sweetly and musically rough. I would not for anything have it different.

What a vexatiously pleasant time I had, years ago, in tracing the voice home to its author! How vividly I remember the day when I lay flat on my face in a woodland path, opera-glass in hand, a manual open before me, and the bird singing at intervals from a pine tree opposite; and a neighbor, who had known me from boyhood, coming suddenly down the path. I may err in my recollection (it was long ago), but I think I heard the music for weeks before I satis- 
fied myself as to the identity of the singer. "Trees, trees, murmuring trees:" so I once translated the first of the two songs; and to this day I do not see how to improve upon the version. $\mathrm{He}$ is talking of the Weymouth pine, I like to believe.

Black-and-white creeping warblers have been common since the 4 th (under normal weather conditions they should have been here a fortnight sooner), and on the 6 th the oven-bird took possession of the drier woods. He looks very little like a warbler, but those who ought to know whereof they speak class him with that family. I have not yet heard his flight song, but he has no idea of keeping silence. As is true of every real artist, he is in love with his part. With what a daintily self-conscious grace he walks the boards! It is a kind of music to watch him. He makes me think continually of the little ghost in Mrs. Slosson's story. Like that insubstantial reality he is always saying: "Don't you want to hear me speak my piece?" And whether the answer is yes or no, it is no matter - over he goes with it.

Yesterday my first blue yellow-back was 
274 THE CLERK OF THE WOODS

singing, and to-day (May 8) the first chestnut-sides are with me. And there are numbers to follow. From now till the end of the month they will be coming and going a procession of beauty. In my mind I can already see them: the gorgeous redstart, the lovely blue golden-wing, the splendid magnolia, and the more splendid Blackburnian, the Cape May (a "seldom pleasure"), and the multitudinous blackpoll these and many others that are no less worthy. At this time of the year a man should have nothing to do but to live in the sun and look at the passing show. 
INDEX 



\section{INDEX}

Alder, 159. black, 135.

Anemone, 3.

Apple, 51.

Arbutus, trailing, 4, 143.

Asters, 59, 120.

Azalea, swamp, 22.

Barberry, 111, 172.

Bayberry, 136.

Beech, 163.

Bees, 58.

Birch, sweet, 119, 160.

Bittern, 31. least, 30.

Bitternut, 113.

Blackbird, erow, 120, 240. red-winged, $39,240,241$, 254.

rusty, 155.

Blackberry, 172.

Bladderwort, 22.

Blneberry, 123, 136, 166.

Bluebird, $16,52,83,120$, $217,230,231,234$.

Bobolink, 19, 52, 83.

Butter-and-eggs, 114.

Butterflies, 57, 85, 108.

Canna, 62, 115.

Catbird, 6, 7.

Catnip, 54.
Cat-tail, 28.

Cedar, red, 39, 172.

Checkerberry, 161, 174, 176.

Cherry, rum, 123.

Chestnat, 34.

Chewink, 24.

Chickadee, black - capped, $22,60,64,66,67,73,134$, $150,153,154,182,205$, 206, 234, 239.

Chicory, 27.

Chipmnnk, 182, 226, 227.

Chokecherry, 41.

Clethra, 122.

Clover, rabbit-foot, 23.

Coffee-tree, 125.

Columbine, 3.

Corn, 52.

Cornel, dwarf, 4.

Cowbird, 235.

Cowslip, 3.

Creeper, brown, 155.

Crickets, 65.

Crossbill, red, 154. white-winged, 154.

Crow, 24, 39, 42, 65, 154.

Dahlia, 115.

Dangleberry, 123, 174.

Desmodinm nudiflorum, 36.

Duck, dusky, 102. 
Finch, Lincoln, 70. pine, 155. purple, 8, 155, 203, 219, $225,231$.

Flicker, 64, 155, 231.

Flycatcher, least, 6.

Forsythia, 2.

Fox, 183, 258.

Frog, spade-foot, 262. wood, 257.

Frost grape, 111.

Galinm, yellow, 21.

Gallinule, Florida, 32.

Gerardia, 36.

Goldenrod, 59, 121.

Goldfinch, 8, 27, 63, 134, $136,155,234$.

Goose, Canada, 198.

Grass, 50, 76.

Grosbeak, rose-breasted, 5, 47, 72.

Grouse, ruffed, 83, 133, 143, 155.

Gull, black-backed, 108 . herring, 95, 108, 111, 156 , 238.

Hardhack, 21, 37, 38, 39.

Hawk, red-shouldered, 239. marsh, 108, 254.

Heron, great blue, 94 .

green, 31.

night, 31.

Holly, 150, 175.

Hnckleberry 123, 172.

Hummingbird, 58, 61, 88.

Indigo-bird, 47, 70.

Jay, blue, 38, 120, 125, 154, $204,221$.

Jewel-weed, 26, 58, 62.

Joe Pye weed, 57.
Kingbird, 6, 24, 40, 52 .

Kingfisher, 253.

Kinglet, golden - crowned, $134,155,182$.

Lady's-slipper, 4.

Lark, shore, 107. meadow, 19, 132, 234, 236.

Leucothoë, 164.

Loosestrife, swamp, 57.

Lucky-bug, 57.

Maple, red, 122, 124. striped, 124.

Maryland yellow-throat, 6 , 60.

Mayweed, 54, 114.

Meadow-beauty, 37.

Meadow-sweet, 21.

Morning-glory, 26.

Mullein, 21.

Muskrat, 136, 259.

Nuthatch, red - breasted, 154.

white-breasted, 35,154 , 205, 209, 225, 235.

Old-maid's pinks, 54 .

Old Squaw, 156.

Oriole, Baltimore, 5, 7, 39, 60.

Otter, 259.

Oven-bird, 7, 273.

Owl, screech, 248.

Partridge-berry, 150.

Pennyroyal, 38.

Phoebe, 22, 40, 60, 233, 240.

Pickerel-weed, 29.

Pine, pitch, 35.

Plover, black - bellied, 92, 97,99 . 
Quail, 41, 155.

Quince, 115.

Rail, Carolina, 31, 33. Virginia, 31.

Raspberry, 21.

Redpoll, 153, 154.

Redstart, 7, 12, 55, 274.

Robin, 60, 67, 155, 232, 255.

Rose, swamp, 26.

Sandpiper, pectoral, 98. red-backed, 99, 109. white-rumped, $93,94,96$, $97,100,109$.

Sassafras, 3, 124, 166.

Saxifrage, 3.

Shadbush, 3.

Shrike, 155, 240.

Snipe, 25, 254.

Snowbird, 134, 154, 155, $234,252$.

Sparrow, chipping, 19, 70, 271.

English, 14, 16, 52, 156.

field, 24,39 .

fox, $235,244,250,255$.

grasshopper, 17.

Ipswich, 102.

savanna, $18,107$.

song, $19,38,60,68,234$, $235,253$.

swamp, 13, 22.

tree, 134, 136, 154, 155.

vesper, 19, 24, 253.

white-throated, 6,69 .

Spatter-dock, 29.

Spice-bush, 3, 123, 162.

Squirrel, gray, 118, 227, 259.

flying, 177, 259.

red, $227,259$.

Swallow, barn, 38.

tree, $15,16,237$.

Swift, 38.
Tanager, scarlet, $36,47,60$, 72.

Thimbleberry, 21.

Thorn, 111.

Thoronghwort, 38 .

Thrasher, brown, 23, 270.

Thrush, northern water, 13, $61,71$.

Swainson, 7, 69. wood, 7.

Titlark, 93，94，102，107, 108.

Veery, 6, 23.

Vireo, Philadelphia, 71.

red-eyed, 7, 55, 73.

solitary, 23.

warbling, $6,60,67$.

yellow-throated, 6,60 , 67.

Warbler, black-and-white, 273.

Blackburnian, 274.

blackpoll, $68,73,274$.

black-throated blne, 10.

black-throated green, 23 , $73,272$.

blue golden-winged, 274.

Canadian, 22.

Cape May, 274.

chestnut-sided, 7, 274 .

golden, 6, 267.

magnolia, 274.

myrtle, 73, 136, 269.

Nashville, 7, 268.

parula (blue yellowbacked), 6,274 .

pine, $68,270$.

prairie, 7 .

yellow palm, 271.

Waxwing, cedar, 8.

Waxwork, Roxbury, 111, 124. 


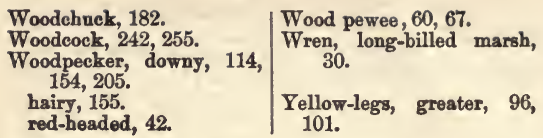





\section{Cob liberside prest \\ Electrotyped and printed by H.O. Houghton \& Co. Cambridge, Mass., U.S, A.}








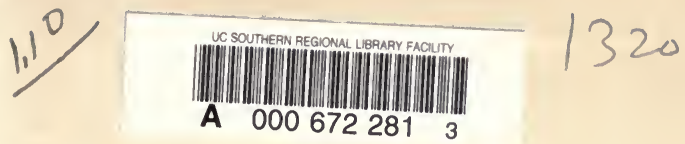


